UNIVERSIDADE DE SÃO PAULO

CLAUDIA ERTHAL

DA EXPERIÊNCIA DO USUÁRIO MIDIÁTICO CONTEMPORÂNEO:

OLHARES EM CONSTRUÇÃO

São Paulo

2018 
CLAUDIA ERTHAL

\title{
DA EXPERIÊNCIA DO USUÁRIO MIDIÁTICO CONTEMPORÂNEO: OLHARES EM CONSTRUÇÃO
}

\begin{abstract}
Tese apresentada à Escola de Comunicações e Artes (ECA) da Universidade de São Paulo, como parte dos requisitos necessários para a obtenção do título de Doutora em Ciências pelo programa de Meios e Processos Audiovisuais.
\end{abstract}

Área de Concentração: Meios e Processos Audiovisuais.

Orientador: Prof. Dr. Mauro Wilton de Sousa. 
Autorizo a reprodução e divulgação total ou parcial deste trabalho, por qualquer meio convencional ou eletrônico, para fins de estudo e pesquisa, desde que citada a fonte.

Catalogação na Publicação

Serviço de Biblioteca e Documentação

Escola de Comunicações e Artes da Universidade de São Paulo Dados inseridos pelo(a) autor(a)

Erthal, Claudia

Da experiência do Usuário midiático contemporâneo: olhares em construção. / Claudia Erthal. -- São Paulo: C. Erthal, 2018.

$136 \mathrm{p}$.

Tese (Doutorado) - Programa de Pós-Graduação em Meios e Processos Audiovisuais - Escola de Comunicaçōes e Artes / Universidade de são Paulo.

Orientador: Mauro Wilton de Sousa

Bibliografia

1. Flanêur 2. Observador 3. Espectador 4. Usuário 5. Espectador I. Sousa, Mauro wilton de II. Título.

CDD 21.ed. - 302.2

Elaborado por Sarah Lorenzon Ferreira - CRB-8/6888 
Nome: ERTHAL, Claudia.

Título: Da experiência do usuário midiático contemporâneo: olhares em construção.

Tese apresentada à Escola de Comunicações e Artes (ECA) da Universidade de São Paulo, como parte dos requisitos necessários para a obtenção do título de Doutora em Ciências pelo programa de Meios e Processos Audiovisuais.

Aprovada em:

\section{BANCA EXAMINADORA}

Prof.(a) DR.(a)

Instituição

Julgamento

Prof.(a) DR.(a)

Instituição

Julgamento

Prof.(a) DR.(a)

Instituição

Julgamento

Prof.(a) DR.(a)

Instituição

Julgamento

Prof.(a) DR.(a)

Instituição

Julgamento

Prof.(a) DR.(a)

Instituição

Julgamento 
À Janice 


\section{Agradecimentos}

Agradeço à Janice, por ser o maior estímulo e o motivo desta jornada. Por nunca ser uma pessoa acomodada, por ter a sensibilidade, o entendimento e a disposição para conversar e debater sobre qualquer assunto, onde não há limites para se envolver, provocar, criticar e refletir.

À minha mãe, Suraia, por estar sempre na torcida pelo crescimento.

Ao Prof. Dr. Mauro Wilton de Sousa que me orientou com generosidade, sensibilidade e conhecimento, sempre me estimulando a crescer e fazer o trabalho se transformar ao longo do tempo.

Ao Prof. Dr. Jonathan Crary por ter produzido textos provocadores à minha percepção (que foram o começo estimulante desta pesquisa), ter me aceitado como aluna em suas aulas na Columbia University e por ter aberto as portas para uma conversa generosa que trouxe informação, crítica e sugestões de leitura fundamentais para o desenvolvimento deste trabalho.

A Celso Gianinni e Roberto Mafra pela parceria, amizade e revisões.

À Patrícia Stifelman pelo incentivo e amizade e hospedagem.

À Denise Cunha Sobrinho, pelas conversas e pela compreensão de que pesquisa exige tempo e dedicação. $E$ aos colegas de redação que sempre demonstraram 0 companheirismo que longos projetos exigem.

À Claudia Dominguez que faz parte desse caminho.

Aos amigos e ao estímulo de todos. 


\section{Resumo}

ERTHAL, Claudia. Da experiência do Usuário midiático contemporâneo: olhares em construção. 2018 - 136 f. Tese (Doutorado em Meios e Processos Audiovisuais) - Escola de Comunicações e Arte, Universidade de São Paulo, São Paulo, 2018.

Esta pesquisa desenvolve uma análise crítica a partir de uma noção histórico-teórica do processo de construção da relação das pessoas com a mídia na contemporaneidade e está dividida em três momentos: o Observador no século 19; o Espectador no século 20; e o Usuário no século 21. Assume que estes constituem três sujeitos comunicacionais, possuem trajetórias interligadas e podem ser vistos como um sujeito múltiplo. O trabalho parte dos seguintes pressupostos: a transformação do comportamento dos sujeitos; o acúmulo de percepções e conhecimentos; e as mudanças nos modos de ver e nas maneiras de se relacionar que se dão a partir de uma construção sociocultural, política e econômica. Busca compreender a existência de um Observador/Espectador/Usuário e as mediações tecnológicas que Ihe servem como contexto. Vê o Usuário: a partir do Flanêur de Benjamin - como uma referência comunicacional ao sujeito/objeto na formação do seu olhar; como reconfiguração do sujeito/receptor na história e de sua relação com a mídia e com a sociedade; como a dimensão tecnológica permeia a diferenciação dos sujeitos comunicacionais e o contexto social no qual estão inseridos, privilegiando a tecnologia e em seu lugar político e social, e de como o comportamento deste sujeito pode ser atribuído a esses lugares. Trabalha a Percepção na medida em que se aproxima do Usuário/Flanêur numa conjugação em que os dois se distinguem mesmo que em tempos e circunstâncias diversas na experiência comunicacional.

Palavras-chave: Flanêur. Observador. Espectador. Usuário. Tecnologia. Percepção. Comunicação. 


\section{Abstract}

ERTHAL, Claudia. Of the contemporary mediatic User experience: perspectives under development. 2018 - 136 pages. Thesis (PHD in Audiovisual Medium and Processes) - School of Communication and Arts, University of São Paulo, São Paulo, 2018.

This research develops a critical analysis from a historical-theoretical perception of the construction process of people relation with the Media in the contemporary world and it is divided in three moments: the Observer in the $19^{\text {th }}$ century; the Spectator in the $20^{\text {th }}$ century and the User in the $21^{\text {st }}$ century. It accepts that these three communication subjects share connected paths and can also be seen as a multiple subject. This work is based in the following assumptions: the transition in the subjects behaviour; the accumulation of perception and knowledge; and the changes in the ways of seeing and in the ways the relationships happened from a sociocultural, political and economic structure point of view. The research aims to understand the existence of an Observer/Spectator/User and the technological mediations that are used as a background. It sees the User from: Benjamin's Flanêur point of view - as a communicational reference for the development of the subject/object in the construction of the way he sees; as a reconfiguration of the subject/recipient in history and its relation with the Medias and with the society; how the technological dimension pervades the variation between the communication subjects and in the social context in which they are located, with a particular emphasis in technology, and in his political and social place and of how this subjects' behaviour is ascribed to these places. This research also explores the Perception to the extent that it approaches the User/Flanêur in a combination in which the two of them distinguish from each other in the communication experience even in different times and circumstances.

Key words: Flanêur. Observer. Spectator. User. Technology. Perception. Communication. 


\section{Sumário}

Capítulo 1 - INTRODUÇÃO ......................................................................... 11

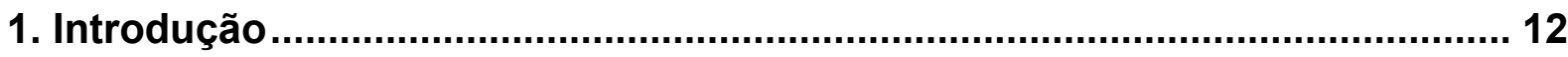

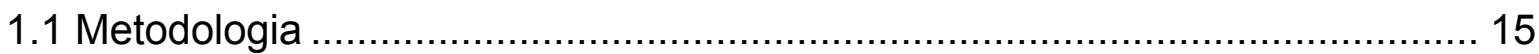

1.2 Implicações conceituais de base ............................................................. 16

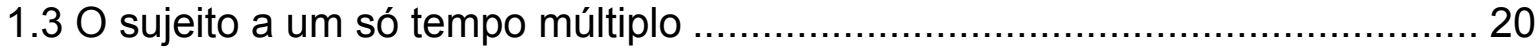

1.4 A contemporaneidade do sono-flanêur.................................................. 21

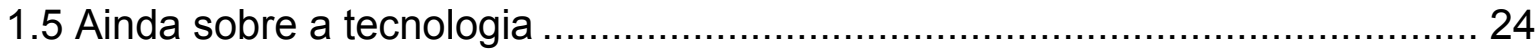

1.6 O sujeito de Foucault e a relação com o Usuário ......................................... 26

1.7 Observações desde Crary e Berardi ................................................... 28

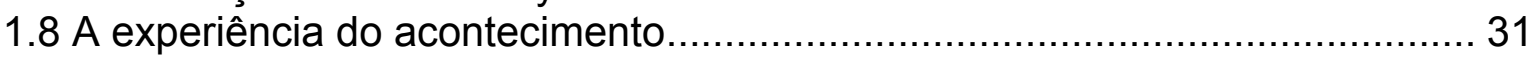

1.9 Técnicas do Observador............................................................. 34

Capítulo 2 - DA PERCEPÇÃO AO USUÁRIO CONTEMPORÂNEO ..................... 43

2.1 O Observador século 19 - a construção do olhar ....................................... 44

2.2 O Espectador do século 21 - a domesticação do olhar ................................ 51

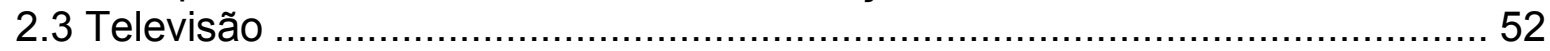

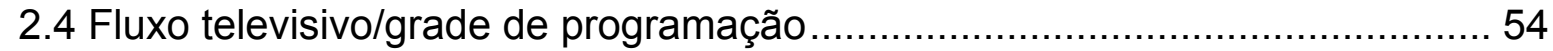

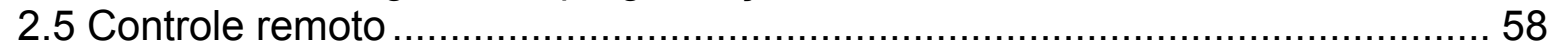

2.5 O Usuário do século 21 - a renovação do olhar ................................... 62

Capítulo 3 - SUJEITO/USUÁRIO: A BUSCA DA IDENTIDADE NA MODERNIDADE

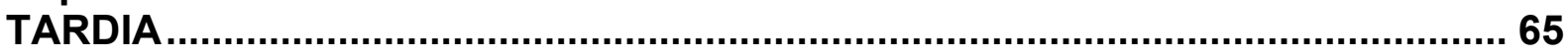

3. Sujeito/Usuário: a busca da identidade na modernidade tardia......................66 66

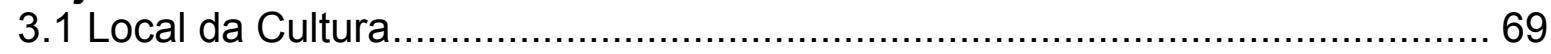

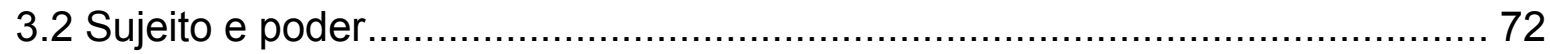

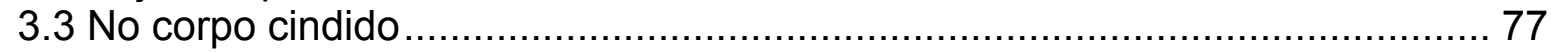

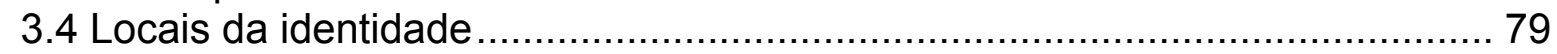

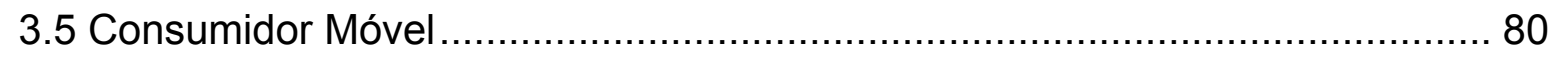

Capítulo 4 - USUÁRIO ‘AO VIVO’ .................................................................... 84

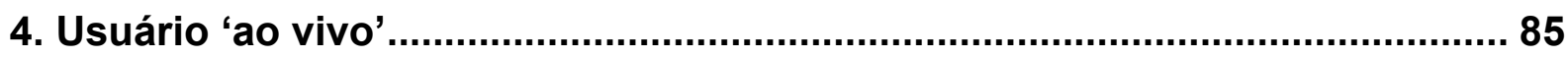

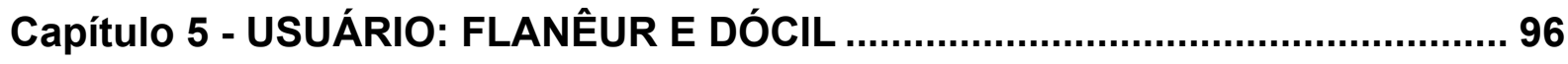

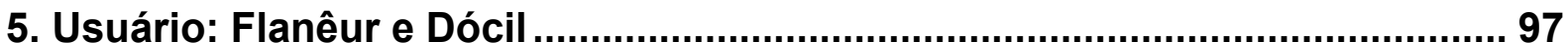

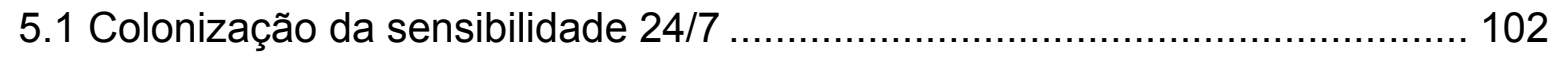

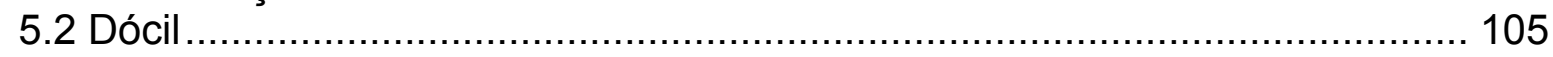

Capítulo 6 - DESDOBRAMENTOS POSSÍlVEIS............................................... 119

6. Desdobramentos possíveis............................................................................ 120

6.1 A colonização da sensibilidade e a mercantilização da atenção.................. 122

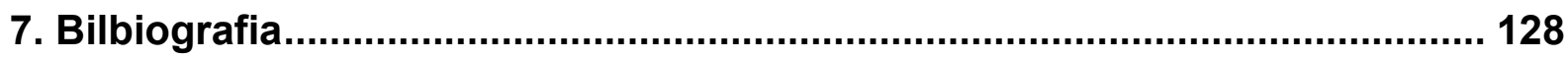



Capítulo 1

INTRODUÇÃO 


\section{Introdução}

É na tentativa de desenvolver uma análise crítica do processo de construção da relação das pessoas com a mídia e que se reconfigura todos os dias diante dos nossos olhos, que este presente trabalho se desenvolveu.

Busca-se realizar um estudo crítico-analítico dos antecedentes que ao longo dos anos recentes construíram a relação das pessoas com os meios de comunicação em três momentos: enquanto o Observador, no século 19, do Espectador, no século 20 e do Usuário, no 21.

Assumindo-os como três sujeitos comunicacionais distintos historicamente e com suas trajetórias ligadas a contatos diferentes com a tecnologia, indaga-se sobre a pertinência de vê-los hoje se expressando como que em um único sujeito: o Observador e Espectador se realizam no Usuário. São três momentos de contato com a mídia em contextos diferentes. Partindo do pressuposto de que houve uma transformação do comportamento dos sujeitos, percebe-se que um acumulou percepções e conhecimentos do outro, modos de ver e maneiras de se relacionar que foram transmitidos em sequência como uma bagagem intuitiva que se dá a partir de uma construção sociocultural, política e econômica.

A motivação que aqui sustenta esse objeto de estudos está no reconhecimento da contextualidade histórica e não apenas circunstancial de um conjunto de valores que desde a economia, desenvolvimento tecnológico e de sua função social e política, econômica e cultural vêm se dando em saltos sequentes construindo uma sociedade plural embora sustentada pelos diferentes tons de um só e mesmo sistema mais amplo. Assume-se, pois que os momentos históricos que distinguiram a sucessão de relações das pessoas com as diferentes mídias marcaram diferenças e singularidades que se reproduzem e se completam ainda que se expressando de forma e condições que marcam a hipótese de um estágio de “Múltiplo Usuário' ainda em processo.

Na busca de compreender quem são, ou quem é o Observador/Espectador/Usuário o estudo das mediações tecnológicas que Ihes foram tidas como contexto é talvez 
um dos indicadores principais para seu estudo. Os dispositivos de exibição de imagens em movimento na época pré-Cinema, como o Fenacistoscópio e o Estereoscópio no século 19; a Televisão no 20 e a Internet no 21 são elementos essenciais para compreender a trajetória evolutiva do que aqui denominamos como sujeito objeto do estudo, na verdade o sujeito comunicacional de todo esse processo.

Vários traços culturais e práticas de comunicação podem ser apontados, ainda que de forma inicial, para exemplificar como as tecnologias se colocam como mediação constitutiva da diferença nestas mesmas práticas de comunicação ao longo da história:

1) O Observador se situa no contexto histórico de um tempo ainda marcado pelo contemplativo, o tempo da literatura, pintura e poesia, sinais de um subjetivo e reflexivo de um momento pré-midiático. Um momento na formação do olhar no qual as mídias existentes não ocupavam o centro das atenções deslocando o sujeito do centro e colocando-o em sua função como acontece atualmente. As mídias no contexto sugerido não eram um modelo de negócio predominante ou, sob alguns aspectos, nem eram ainda um negócio.

2) Por outro lado, pode-se também admitir que o contato com as tecnologias em décadas mais recentes fizeram deste sujeito um Espectador como bem lembra Adorno (2006), entre outros. Veremos que o tempo do Espectador era um tempo da passividade de quem assiste a um fluxo de informação. Neste caso, principalmente o fluxo televisivo do qual fala Williams (1974), e que lhe é colocado e recebido de maneira passiva e introjetado mesmo não sendo algo de sua natureza, mas que se torna um hábito cultural e a retroalimentação de um amplo modelo social e econômico capitalista. Este Espectador habita um tempo que o conduz para uma nova chave numa sociedade do espetáculo como lido em Debord (2003).

3) E, por último, sugere-se refletir sobre o Usuário, que na era digital e virtual se revela em fragmentações do ser e das ideias, num fluxo de atenção permanente que contém algo de passividade, mas talvez não de reflexão, reservando para o sujeito um local dúbio: ele se tornaria o centro das atenções porque a sua interação com as mídias é essencial para que estas possam existir e os modelos de negócio são desenvolvidos a partir da interação. 
Por outro lado, a ação do Usuário na Internet também seria recebida pela rede e pelas empresas as quais ele acessa como apenas mais um algoritmo que mesmo essencial para o funcionamento da rede - o trata sempre como um cliente a ser fidelizado e que deve dispensar o máximo de atenção e fornecer o máximo de trabalho para o ambiente virtual. Portanto, a partir da noção da necessidade de acesso permanente ao ambiente virtual, acontece também a dedicação de atenção e de fornecimento de informações para alimentar um sistema midiático/informacional. O Usuário experimenta, então, um universo onde é destituído de subjetividades e de momentos de reflexão longe da rede, um universo que o exclui no momento em que está desconectado e o coloca numa posição de invisibilidade e de não pertencimento, não deixando margem para negociações.

As três indicações não parecem se mostrar inicialmente excludentes. Ao contrário: se transformam e sugerem a visão de um único sujeito híbrido, envolvido em suas aquisições culturais, ao se tornar essa mescla num terceiro elemento que se estabelece como um terceiro sentido (BARTHES, 1982) para a leitura da comunicação. Em momentos históricos diferentes, porém afins, o sujeito que se utiliza da tecnologia e dos dispositivos de mídia se depara com um modo de ver completamente diferente do que tinha até então, imenso em possibilidades e mobilidades.

Essas observações não impedem a problematização a respeito, ao contrário, as acentua: a questão que conduz à reflexão de sobre até que ponto a contemporaneidade das mediações que hoje caracterizam o Usuário atual têm a ver ou não com perspectivas que marcaram o Observador de anteontem, o Espectador de ontem e o Usuário, leva a uma indagação de base, já apontada, sobre se há uma reconfiguração ou uma atualização de processos anteriores no hoje. E leva também à reflexões: de como se porta hoje o Usuário contemporâneo dentro dessa percepção; se ele traduz ou não traduz os aportes anteriores de uma percepção antiga, de uma percepção Flâneur, por assim dizer, daquele que simplesmente olha e consome. Ou se ele é um Espectador que vê, reflete e tem opção. Por fim, qual é seu envolvimento neste contexto?

Devido a esta trajetória tecnológica e social, o Usuário possui aspectos de um sujeito midiático/filosófico contemporâneo que parece guardar semelhanças com o Observador do século 19. É uma indicação que acontece a partir de Crary (1990 e 
2014) ao relacionar com o percurso do Flanêur de Benjamin. ${ }^{1}$ (2007) Após refletir sobre o Observador e o Espectador e chegar ao Usuário no século 21, retoma-se também Benjamin para olhar este último sujeito segundo o Flanêur. Trata-se de um ir e vir à figura do Flanêur como referência comunicacional ao sujeito/objeto desta pesquisa e uma espécie de trampolim na formação do seu olhar.

Observador/Espectador/Usuário diferem entre si na medida em que são participantes de momentos históricos diversos, mas constituem um só nas atribuições e aquisições da técnica, a essência de algo que cada um destes sujeitos busca, mas que já é, no entanto, intrínseca para o Usuário que é o sujeito final, um detentor nativo dessa a contexto é talvez atribuição na sua essência.

O trabalho é um esforço de analisar teórica e historicamente a démarche que coloca um determinado processo da relação das pessoas ao terem uma percepção diferente da mídia nos três momentos de referência para o texto. O problema tornase, assim, a questão da reconfiguração do sujeito/receptor na história, de sua relação com a mídia e com a sociedade tentando identificar aquilo que ele tem hoje de aportes anteriores ou não; a dimensão tecnológica que permeia a diferenciação e o contexto social no qual está inserido privilegiando a tecnologia; seu lugar político e social e que pode ser atribuído a este lugar e comportamento. Uma questão múltipla com derivações, mas que conduz a um mesmo lugar de percepção do sujeito comunicacional: um indivíduo que lida com variáveis ao longo de uma cronologia e que convive com fatores que perturbam, no sentido de afetar essas diferenciações.

É uma busca de qualificação da hipótese de estarmos vivenciando hoje a experiência de Usuário Múltiplo, que guarda em si uma relação com a tecnologia e com a sociedade muito mais semelhante do que distinta de outros processos. São questões presentes de forma intensa na dependência e realidade das relações crescentes das pessoas com a mídia, coisa que não aconteceu em tempos anteriores da forma como está configurada na contemporaneidade.

\subsection{Metodologia}

O presente trabalho de uma reconfiguração histórica desses três momentos parte da literatura dos estudos disponíveis a respeito, tentando configurar a reflexão

\footnotetext{
${ }^{1}$ O texto de Walter Benjamin é Paris, capital do século XIX, originalmente publicado em 1935.
} 
a partir dessa bibliografia de autores, e de uma suposta junção que teria se tornado uma característica do Usuário contemporâneo, ao mesmo tempo um sujeito híbrido mesclando características do Observador e do Espectador trazidas numa bagagem intuitiva/emocional.

Dentro dessa perspectiva, para trabalhar essa metodologia, a pesquisa vai se basear sobretudo no peso das tecnologias de ontem - a configuração da modernidade - e até que ponto nessas três questões, a tecnologia permeou o processo que não é isolado da técnica, mas baseada, por exemplo, em meios de comunicação como Rádio, TV ou Internet.

\subsection{Implicações conceituais de base}

A título de aportes de apoio à indagação aqui proposta importa, mais que o desenvolvimento de um quadro teórico de referência, indicar balizas conceituais que sustentam o desenvolvimento do trabalho.

O tema da Percepção se aproxima ao do Observador, tanto quanto ao do Flanêur, numa conjugação em que se distinguem, ainda que em tempos e circunstâncias diversas, mas provavelmente tenham na experiência um traço comum.

Para desenvolver uma percepção sobre este sujeito múltiplo e também de como ele percebe o próprio universo busca-se recursos em Merleau-Ponty (1999) que pergunta se num momento primordial quando ainda não possuímos ideia préconcebida, o que nos afeta primeiro é a percepção que temos das coisas, e a maneira como chegam à nossa sensibilidade ou é o nosso pensamento elaborado acerca das coisas que nos afeta? Ele afirma que a percepção é o nosso primeiro contato. É o que Merleau-Ponty chama de vida pré-reflexão. Para ele há uma relação sensível como mundo que passa pela sensibilidade antes de se transformar em algo prático.

A origem do modo de existir e uma forma de perceber o sujeito que se desenha nesta pesquisa também conduz a entender o Flanêur como uma forma de 'pré-usuário'. Ele tem o primeiro contato com a novidade, as Passagens, diria Benjamim, na virada do 19 para o 20, ainda num mundo pouco mediado, e no início de uma sociedade midiatiza como conhecemos. Não dispõe de ferramentas para se 
interpor a esta mediação e lida com o universo e as informações que tem e com a vida acerca das coisas em si, como são e como são dadas. Ainda não existe ali um pensamento crítico sobre a mediação do social, a regulação e a disciplina. Não é, portanto, ainda uma construção, mas um modo de sentir o mundo. Ele pode ser relacionado com o que Crary, a partir do de Maine de Biran, chama de "corpo inquieto, ativo, cuja impaciente motilité (isto é, o esforço deliberado diante da sensação de resistência) era uma precondição para a subjetividade". (CRARY, 1990, p. 75) A mobilidade do Flanêur é uma forma de conhecer o entorno/ambiente, desvendá-lo e se deixar se afetado por ele e não ser ainda o passivo massificado no qual o Espectador irá se tornar.

O Flanêur com as Passagens se liberta das formas investigativas de regulação e disciplina do século 19 para passar por um breve período onde lida com o mundo ainda com a midiatização em seus estágios iniciais se comparado com o que se tornaria no século 21. Ele lida com o mundo com as ferramentas vivas e se comporta como um sujeito 'ao vivo' assim com o Usuário.

O 'perceber' é um ato de estar aberto para o contexto. Tem em si todo o processo de um Usuário que se conecta e uma dimensão de coletividade. 'Perceber' assume também a dimensão do ato de se localizar. O que se tenta aqui é estabelecer um nexo de que a percepção não é um dado individual é um dado de coletividade histórica entre o sujeito ativo na comunicação e o meio no qual está inserido. Entender também qual a capacidade de intervenção do contexto para que ele seja qualificado como um Flanêur ontem e um novo Flanêur hoje.

Essa dimensão da percepção como uma evocação dos sentidos que precede a racionalidade do conhecimento, tem sua exemplificação especialmente na perspectiva de Benjamin quando assinala:

\footnotetext{
"Aquela embriaguês anamnésica, na qual o flanêur vagueia pela cidade, não se nutre apenas daquilo que Ihe passa sensorialmente diante dos olhos, mas apodera-se frequentemente do simples saber, de dados inertes, como de algo experienciado e vivido. Esse saber sentido transmite-se de uma pessoa a outra, sobretudo oralmente." (BENJAMIN, 2006 (pg.462)
}

Atente-se para a dimensão então apontada por Benjamim quanto à passagem da experiência sensível para o saber racional e sua interlocução social, ou aquilo que em outro momento ele indica: 
“...não foram os forasteiros mas o próprios parisienses que fizeram de Paris a terra prometida do flanêur, 'a paisagem construída de pura vida', como Hofmannsthal certa vez a chamou. Paisagem - é nisso que a cidade se transforma para o Flanêur. Ou mais precisamente: para ele a cidade cinde-se em seus polos dialéticos. Abre-se para ele como paisagem e fecha-se como quarto" (Idem, pag.462).

Duas dimensões conceituais estão presentes como substrato da interpretação dada por Benjamim:

1) de um lado, o dimensionamento feito por ele sobre a relação entre a percepção e o mundo da experiência, eixo fundamental e complexo de sua filosofia;

2) de outro lado, na derivação da crise da experiência na contemporaneidade, novo mundo de sentidos sendo abrangido quanto ao significado das tecnologias na construção contemporânea dessas mesmas experiências-vivências.

É na sequência das várias fases de desenvolvimento de seu pensamento e dos vários textos produzidos a respeito, que o conceito de experiência - Erfarung se reporta à construção coletiva de sentidos e vivências, e que cada vez mais se coloca ausente na Modernidade e, como tal, um dos fatores da pobreza cultural contemporânea:

\footnotetext{
"Qual o valor de todo nosso patrimônio cultural se a experiência não mais a vincula a nós? A horrível mixórdia de estilos e concepções do mundo do século passado mostrou-nos com tanta clareza aonde esses valores culturais podem nos conduzir, quando a experiência nos é subtraída, hipócrita ou sorrateiramente, que é hoje em dia uma prova de honradez confessar nossa pobreza. Sim, é preferível confessar que essa pobreza de experiência não é mais privada, mas de toda a humanidade. Surge assim uma nova barbárie." (Ibidem, p. 115)
}

Essa postura crítica é que possibilita distinguir experiência de vivência (Erlebnis),- assinalando aquela como um patrimônio coletivo e cuja ausência hoje propicia a pobreza da própria vivência cotidiana atual.

A mediação da técnica ontem, no contexto de sentidos sendo percebidos e vivenciados, como na experiência do Flanêur, hoje se define pela urgência e indispensabilidade das tecnologias, condição de experiência-vivência, portanto de redefinição da linguagem: "uma nova forma de miséria surgiu com esse monstruoso desenvolvimento da técnica, sobrepondo-se ao homem. (Ibidem, pag.115)

Nesse contexto evidencia-se a significação do desenvolvimento atual da técnica ainda que sob os pressupostos críticos de Benjamin. Os usos da tecnologia 
pelo sujeito comunicacional, especialmente nos dias atuais, proporcionam uma reformulação social e o trajeto que vem da tecnologia vertical para a tecnologia horizontal. Hoje esses campos são amplamente comunicantes e se contaminam de maneira permanente numa sociedade de compartilhamento e trabalhos coletivos ou individuais, gerando uma retroalimentação constante: o Usuário utiliza a tecnologia, gera novas necessidades e auxilia na criação de mais tecnologia que vai responder à novas questões e necessidades de outros Usuários.

Esse trabalho fala da contribuição da evolução tecnológica para a trajetória e construção de um sujeito midiático, numa primeira percepção composta por três etapas cronológicas - o Observador do século 19; o Espectador do século 20 e o Usuário do século 21 - conectadas pela tecnologia, seus dispositivos e usos, e que é percebida como o elo entre estas etapas e sujeitos.

Há uma evidência de que a formação do sujeito se deve também por causa do contato com a tecnologia. E há, ao mesmo tempo, a indagação sobre o fato de ele ser o Usuário dos meios e dispositivos tecnológicos e se este uso pode constituir, assim, um aspecto da formação do olhar midiático na contemporaneidade. A partir daí se construiria a percepção de que o sujeito da pesquisa teria uma trajetória proveniente do Observador do século 19 a um Observador/Usuário do século 21. A pesquisa trabalha no âmbito de compreender e estabelecer comprovações sobre as noções que permeiam o percurso caracterizado por questionamentos a respeito de como o processo comunicacional se modificou enquanto comunicação através da tecnologia.

Esta não é somente uma trajetória do tempo, ou que se volta totalmente para a noção histórica de um percurso. Mas um caminho a ser percorrido pelo Usuário no que diz respeito à compreensão/mutação do modo de ver a comunicação. É a visão de mundo do Usuário no que se refere à relação social, ao processo interativo e aos valores que permeiam a comunicação. Estas são noções que devem guiar a pesquisa que também trata das matrizes técnicas e das mediações que estariam presentes não apesar da técnica, mas com a técnica; do que se cria de social a partir desse contato e que está mais voltada para os aspectos filosóficos sobre a formação do sujeito midiático.

Os aspectos concretos de tal sujeito apontam para um momento do seu desenvolvimento - ele é um sujeito que muda constantemente - porque mesmo que 
o percurso seja conhecido do século 19 até agora, o que ele tem de século 21 se forma e constitui esse novo sujeito todos os dias.

\subsection{0 sujeito a um só tempo múltiplo}

A pesquisa vislumbra um sujeito que viaja num tempo cronológico a partir de um contato com a tecnologia e que, com seu uso, descortina técnicas e proporciona a si próprio ressignificações. Transporta consigo uma bagagem cultural adquirida pela prática que se revela intuitiva na medida que aplica este conhecimento nas mídias transformadas e recriadas.

O objeto sobre o qual se estabelece a indagação é o sujeito Observador/Espectador/Usuário no processo comunicacional desmembrado ao longo do tempo com características diferentes, não é como sujeito histórico tal qual em Marx ou Weber. É um sujeito que também é o objeto que acontece projetado num universo de relações com várias facetas tornando-o um sujeito único, singular $e$ detentor de características de um coletivo cultural e social: o sujeito Observador de Crary, o Flâneur a partir do Benjamin, o Espectador de Williams e Usuário do Crary novamente. Um objeto conceitual e temático que não é pontual e que é formado por estes sujeitos numa trajetória histórico-tecnológica.

O Sujeito/Observador/Espectador/Usuário tratado aqui é um ser híbrido comunicacional, entendendo-se por híbrida a noção do Usuário, uma terceira figura que se delineia a partir das ideias de Observador e Espectador. Olhando de maneira tendencial, ele não deixa de ser Observador, não deixa de ser Espectador mas é um ser que mudou e traz consigo uma ressignificação como Usuário de mídias contemporâneas. Um ser imbricado e despolarizado, uma mescla, de possibilidades e de interpretações. Um sujeito que não é neutro porque se manifesta o tempo todo. E se não há neutralidade há identidade. Possui a identidade de se posicionar diante do diverso e assume a diferença. Não aparenta ser um consumidor tradicional porque sua compra não é do igual, mas do diferente. No entanto, se posiciona nas 'Passagens' da Internet em busca da novidade que move o contemporâneo midiático. Mas não parece um Usuário passivo e sem percepção porque carrega consigo elementos do Flâneur que não atuou como um neutro e que em sua trajetória buscava o sentido das coisas ao redor. Mesmo sem dispor de tecnologias 
de mediação o Flanêur estava diante da vida como ela é, das coisas como elas são, e incorporava o seu sujeito à realidade com toda a bagagem individual. Portanto, este sujeito é híbrido mas não é um híbrido neutro. É um outro que não parece caber simplesmente numa racionalização exata de somas entre elementos, mas numa terceira coisa que se desenvolve e se recria todos os dias.

A pesquisa em curso se propõe a refletir sobre a ressignificação do sujeito, de como se dá este habitar um social comunicacional/midiático, das formas de atuação nesse campo de produção de informação, interação e dedicação da atenção na contemporaneidade.

O sujeito e sua relação com o contrato de poder social e institucional a partir de leituras de Foucault também é relevante para a pesquisa, porém a importância se dá mais pela relação entre este sujeito e o poder do que propriamente na formação original do sujeito/objeto de estudo deste trabalho. Os conceitos de Foucault dialogam com os teóricos em questão, mas estão voltados mais para a percepção do sujeito no que diz respeito às relações de poder do que na formação do sujeito comunicacional propriamente dito.

O sujeito da pesquisa não é o sujeito da comunicação per se, é o sujeito que usa a tecnologia e a comunicação advinda desta tecnologia que se torna objeto de trabalho. É um sujeito autor/ator no social dos dispositivos de mídia, é um indivíduo, mas não um sistema econômico em si. Ele existe a partir dos usos da tecnologia no processo comunicacional. E compreende conceitos ligados à atuação, produção de informação e uso da informação no social.

\subsection{A contemporaneidade do sono-flanêur}

A tecnologia midiática está presente no cotidiano contemporâneo com a Internet e todos os dispositivos e aplicativos disponíveis para o acesso aos produtos audiovisuais em várias telas e não mais somente a partir da televisão ou do cinema. O Usuário das diversas mídias e dispositivos móveis se transforma também em um produtor de informação através das publicações em texto, foto e vídeo. O que se tenta analisar aqui é se este Usuário guarda semelhanças com o Observador do século 19 (CRARY, 1990) de uma época pré-Cinema diante do novo que lhe foi oferecido então, e é oferecido hoje, com as possibilidades criativas e de 
transformação social que as novas mídias, dispositivos e formas de comunicação apresentavam à época e apresentam agora. Há neste ponto a percepção de uma trajetória e de uma noção de transformação do Observador em Espectador do século $20 \mathrm{com}$ os meios de comunicação de massa - tendo na Televisão o seu principal ponto de apoio - e em Usuário de mídias e dispositivos móveis na atualidade. Tal percepção remete à transformação da sociedade da informação onde estava o Espectador para a sociedade do conhecimento para onde está o Usuário nas primeiras décadas do século 21 .

Para construir um olhar de transformação do sujeito, é importante perceber que a relação do indivíduo com o meio descrita no Flanêur $^{2}$ de Benjamin trouxe a esta pesquisa a noção de movimento, mobilidade, consumo, abertura para a novidade para as transformações do cotidiano através do desenvolvimento arquitetônico. $\mathrm{O}$ assunto será tratado mais adiante quando falarmos especificamente do Flanêur.

A perspectiva frankfurtiana parte de um pressuposto de que o sujeito é Espectador de uma cultura massiva, dentro de uma noção de um Usuário passivo nessa dimensão de nível individual fruto do sistema. No texto Paris, capital do século XIX, Benjamin fala das Passagens arquitetônicas como o local daquele momento contemporâneo que transporta o indivíduo para uma nova época. Nos dias de hoje a Passagem dos novos Flanêurs/Usuários está acessível na 'palma da mão' com os novos dispositivos tecnológicos.

Benjamin refletiu e teorizou sobre o caminhar na cidade em termos econômicos, culturais, literários e históricos. Utilizou-se do conceito de Flanêur, do modo de estar da cidade em suas longas caminhadas por Paris e por ver nas arcadas uma metáfora para a passagem do tempo e para a entrada na Modernidade. As ideias dele têm uma relevância especial para este trabalho na medida em que o Flâneur serve como uma referência para compreender fenômenos urbanos e da contemporaneidade. Uma questão a ser explorada no corpo do trabalho é se o Usuário de mídias móveis pode ser comparado ao Flâneur no sentido de que possui a mobilidade para se movimentar pelo ambiente/cidade, de

\footnotetext{
2 O termo Flâneur se origina na língua francesa e tem o significado de "vagabundo", "vadio", "preguiçoso" que, por sua vez, vem do verbo flâneur que significa "passear". O poeta Charles Baudelaire desenvolveu um significado para o flâneur como uma pessoa que experimenta a cidade ao caminhar por ela.
} 
que se comunica com o que é transitório e estabelece um critério de transitoriedade para esta relação com o efêmero da visibilidade das redes sociais?

O Flanêur revisto sugere uma liberdade de movimentos ao mesmo tempo em que tem acesso a informações numa esfera global. E porque está conectado reflete a cidade nas redes sociais. O Usuário não faz uma leitura crítica do ambiente com a reflexão num tempo benjaminiano, mas num tempo novo, atual, diferente daquele porque exige uma interação que acontece num outro ritmo de sensações e reações. O fato de utilizar a geolocalização faz com que ele estabeleça novos mapas sócioculturais, reatualize e ressignifique as Passagens para um modo contemporâneo. Será que o FlâneurNsuário atende a uma necessidade individual burguesa de se sobrepor à uma aristocracia, ou para atualizar o tema, de se sobrepor a uma classe social distinta da sua? Talvez não haja resposta para esta questão, mas há uma necessidade de mantê-la pulsando enquanto há a tentativa compreender os movimentos e as necessidades deste sujeito.

O que o Usuário deixa transparecer é que já se tornou um instrumento de massa e exerce um protagonismo instantâneo de uma relação social, desenvolvendo uma identidade a partir da aceitação e visibilidade que recebe dos ambientes virtuais que frequenta. Com as mídias móveis ele tem o tempo do Flâneur para desfrutar da cidade - sendo esta cidade, a cidade mesmo como se conhece e também as novas configurações de ambiente e nação que podem ser estabelecidas a partir da escolha de estar conectado e em contato com os ambientes virtuais que desejar.

No que diz respeito aos aspectos concretos desta relação, para que seja possível ele depende de alguns fatores como um sinal e uma conexão de internet e também de recursos econômicos para mantê-la. Quanto melhor a qualidade da internet e quanto mais amplo for o pacote de dados do Usuário, mais ele expande seus horizontes de acesso no sentido de passar mais tempo conectado e de ter dados disponíveis para acessar uma maior diversidade de material. Claro, depende da relação que estabelece com as redes sociais, comunidades e locais que acessa, para ter mais ou menos contato com os ambientes virtuais. O que importa para esta pesquisa é que ele esteja conectado e as ações que desempenha durante o período que está conectado. 


\subsection{Ainda sobre a tecnologia}

De Heidegger, o trabalho utiliza a ideia de que o aprendizado e a interiorização do uso da tecnologia a partir de um descortinamento da técnica é uma revelação para o sujeito no mundo contemporâneo. Este insight é o que permite ao sujeito a naturalização do uso das mídias no cotidiano. É através do aprendizado que o sujeito faz a transição, a aglutinação e a ressignificação do conhecimento dos séculos 19 ao 21.

Nas redes sociais a comunicação assume o papel de um empoderamento do indivíduo e dos grupos frequentados por ele potencializando a si próprio com suas capacidades individuais e deixando a impressão de que é o protagonista da história.

A ideia de Protagonismo está normalmente relacionada a uma questão mercadológica. Acredita-se que seja importante deixar claro de qual protagonismo estamos falando. De dois tipos ligados por um mesmo recurso: a tecnologia. No seu contato direto e permanente, o Usuário utiliza-a como um processo de visibilidade do sujeito e para isso entra no universo do uso de mídias e dispositivos tecnológicos, móveis ou não, porém conectados.

A outra faceta do mesmo Usuário acontece justamente por conta desse contato constante quando, sob um determinado ponto de vista, pouco interessa qual o tipo de dispositivo com o qual o Usuário está em contato, o que importa para ele é estar conectado. É um sujeito que percebe o mundo através da tecnologia e não apenas através de uma possível ajuda da tecnologia ou de um breve contato com ela. Ele se entende por um ser tecnológico, o Usuário tecnológico é um protagonista deste ambiente com existência a partir da visibilidade que obtém através das interações integradas por ele.

A tecnologia é utilizada como processo de comunicação e sua materialidade é o mundo instrumental dos dispositivos pré-cinema que descortinam a técnica. Heidegger ${ }^{3}$ já demonstrava que o homem utiliza a centralidade da tecnologia através de uma habilidade introjetada para estabelecer o acontecimento comunicacional, a relação/interação com o outro e uma noção de lugar de onde se fala.

Heidegger apresenta uma distinção entre a materialidade e instrumentalidade da tecnologia e a técnica quando diz que a técnica moderna é um meio para fins.

\footnotetext{
${ }^{3}$ No texto A Questão da técnica.
} 
"Por isso, todo esforço para conduzir o homem a uma correta relação com a técnica é determinado pela concepção instrumental da técnica. Tudo se reduz ao lidar de modo adequado com a técnica enquanto meio. Pretende-se como se diz, 'ter espiritualmente a técnica nas mãos'”. (2007, p. 376)

Entrar no campo da fenomenologia da percepção é se dar conta de que esta pesquisa pode ter múltiplas leituras e interpretações que são deixadas como sugestão. Mas por hora, empresta-se apenas a noção de Quiasma de MerleauPonty como "entrelaçamento, reversibilidade [que] designam uma estrutura ontológica (...) [e leva a] 'compreender o que faz, que o sair de si seja entrar em si e vice-versa'" (in DUPOND, 2010, p. 64). Pretende-se, assim, proporcionar este aspecto da compreensão do que o sujeito desta pesquisa faz a tecnologia, de um entrelaçamento de corpo, atenção, gesto e visibilidade quando atua em sua relação com os dispositivos tecnológicos contemporâneos. De maneira abstrata, o sujeito penetra e é penetrado pelo uso dos dispositivos de mídia. É afetado emocionalmente em sua sensibilidade pelos seus usos e por seus atos neles e com eles. Portanto, trata-se de uma interiorização profunda de técnicas e tecnologias ao ponto do sujeito se misturar com essas noções e percepções e fazer delas a sua realidade.

Importante localizar que o sujeito da pesquisa atua na perspectiva de um sociedade urbano-industrial pós-moderna, busca um protagonismo constante e se organiza dentro de um cenário capitalista neoliberal contemporâneo numa sociedade que funciona norteada por conceitos de organização do trabalho e de produtividade e [a sociedade] "desde sempre associa técnica e sociedade pelo viés da comunicação", como nos diz Sousa (2018, p. 21). O autor estabelece uma localização de onde o sujeito fala e que se "configura como um eixo de um ideário do novo modo de ser e de viver em sociedade, do estar junto conectado, da superação de limites que se manifestem inclusive nas práticas mais imediatas da vida". (SOUSA, 2018, p. 19) E diz que o sujeito centralizado e centralizador atua através de

"dinâmicas que envolvem essa mesma centralidade na perspectiva de um mundo compartilhado, dinâmica que Ihe atribui um poder simbólico, proposto e assegurado sob diversos ângulos: ora pela multiplicidade e pluralidade de dispositivos técnicos disponibilizados, ora pelo reconhecimento de seu lugar 
e sua atuação simbólica na criação de novos mecanismos da interação social e de comunidades, ora pela sua presença no espaço público social mais do que no político, proporcionando razões para fazer da visibilidade da imagem técnica e dos dispositivos audiovisuais expressão de consolidação de um certo mundo comum." (2018, p. 19)

É pelos usos dos dispositivos tecnológicos que o sujeito deixa claro que não há mais fronteiras para os relacionamentos que se estabelecem com a mediação da técnica de dispositivos do mundo virtual. $\mathrm{E}$ que a virtualidade já não ocupa mais o lugar apenas de uma tecnologia, mas o espaço do real, porque passou a ser parte fundamental do que entendemos por realidade. O mundo virtual perpassa o real e é transpassado por ele sem que haja para isso qualquer conflito e as experiências de sensibilidade nestes ambientes - e também fora deles - são cada vez mais intermediadas pela técnica.

\subsection{0 sujeito de Foucault e a relação com o Usuário}

Para Michel Foucault a palavra sujeito abarca dois significados: "sujeito a alguém pelo controle e dependência, e preso à sua própria identidade por uma consciência ou autoconhecimento. Ambos sugerem uma forma de poder que subjuga e torna sujeito a" (1995, p. 235). O texto de Foucault estabelece paradigmas para se entender o acordo estabelecido entre o sujeito e as formas de poder, e de como este acordo é um contrato de consentimento. Esta pesquisa não trata tanto de estabelecer adversários para o sujeito, mas relações com estes potenciais adversários que estão naturalizadas na sociedade contemporânea e que são parte de projetos de poder e de conceitos estabelecidos.

A fala de Foucault é sobre as formas do poder, principalmente o social/institucional e constrói uma crítica das formas de individualização e dos procedimentos de totalização. Especifica que não é o poder, mas o sujeito o objeto de estudo dele e diz que a relação com o poder é uma "situação estratégica mais ou menos adquirida e solidificada num conjunto histórico de longa data entre adversários" (Idem, p. 249).

Por isso, cabe prestar atenção ao que diz Giorgio Agamben a cerca de sujeito e dispositivo e que estabelece relação direta com Foucault. Ainda que aqui de 
maneira sucinta, para ele é dispositivo "todo procedimento como qual oikonomia termo grego para a gestão do oikos, da casa - passa a ser traduzido para o ríspido latim dos padres da alta Idade Média como dispositivo." (SCRAMIN et HONESKO in AGAMBEN, 2009, p. 12) A oikinomia de Agamben é um conjunto de práticas, "de saberes, de medidas, de instituições cujo objetivo é gerir, governar, controlar e orientar, num sentido que se supõe útil, os gestos e os pensamentos dos homens". (AGAMBEN, 2009, p. 39)

Ele empresta a definição de dispositivo de Foucault para colocá-lo na categoria de "compreensão do mecanismo contemporâneo" que "passa a ser qualquer coisa que tenha de algum modo a capacidade de capturar, orientar, determinar, interceptar, modelar, controlar e assegurar gestos, as condutas, as opiniões e os discursos dos seres viventes". (AGAMBEN, 2009, p. 40) E diz que o os dispositivos "devem implicar um processo de subjetivação, isto é, devem produzir o seu sujeito".

O autor chama de sujeito o que vem da relação "do corpo a corpo entre os viventes e os dispositivos". (Idem, p. 41) Para ele

\footnotetext{
"os dispositivos são precisamente o que na estratégia foucaultiana toma o lugar dos universais: não simplesmente esta ou aquela medida de segurança, esta ou aquela tecnologia do poder, e nem mesmo uma maioria obtida por abstração: antes, como dizia na entrevista de 1977, 'a rede (le réseau) que se estabelece entre esses elementos'." (AGAMBEN, 2009, pp. 33-34)
}

Afirma que para funcionar um dispositivo "implica um processo de subjetivação, sem o qual o dispositivo não pode funcionar como dispositivo de governo, mas se reduz a um mero exercício da violência" (Idem, p. 46) e lembra que para Foucault

\footnotetext{
"numa sociedade disciplinar, os dispositivos visam, através de uma série de práticas e de discursos, de saberes e de exercícios, à criação de corpos dóceis, mas livres, que assumem a sua identidade e a sua 'liberdade' de sujeitos no próprio processo do seu assujeitamento. Isto é, o dispositivo é antes de tudo uma máquina que produz subjetivações e somente enquanto tal é também uma máquina de governo." (Idem, p. 46)
}

Para lidar com os dispositivos contemporâneos afirma que atuam num processo de "dessubjetivação" do sujeito já docilizado, moldado pela ação e 
"capturado" no dispositivo. Neste caso, a Internet pode ser vista como um dispositivo extremo porque produz tanto a subjetivação como o desmonte dessa subjetivação do sujeito fragilizando-o e docilizando-o ao exigir seu tempo e sua atenção permanentes. Com uma visão bastante cética em relação ao uso da tecnologia ele diz que "as sociedades contemporâneas se apresentam assim como corpos inertes atravessados por gigantescos processos de dessubjetivação que não correspondem a nenhuma subjetivação real". (Idem, p. 48)

Se o sujeito das sociedades democratas pós-industriais tem uma vida controlada por dispositivos nos mínimos detalhes, que "executa pontualmente tudo o que Ihe é dito" seria este, então, "o corpo social mais dócil e frágil jamais constituído na história da humanidade". Caberia ao sujeito atuar sobre o dispositivo no sentido de tornar-se menos subjetivado? Ou atuar no dispositivo, por si só, já é um ato de ser subjetivado por ele? A rebeldia estaria em não atuar, como veremos mais adiante em Crary (2014). Estas são questões propostas para a reflexão ao longo desta pesquisa.

Neste ser humano maquinal em que se transformou o Usuário tudo está em movimento e num movimento humano, como afirma Latour(1994). Ele pergunta de que maneira o homem poderia ser ameaçado pelas máquinas se ele as criou e se faz representar ao construir "seu próprio corpo nelas". Responde que "todos eles [os objetos] foram quase-sujeitos circulando no coletivo que traçavam. Ele é feito destes objetos, tanto quanto estes são feitos dele. Foi multiplicando as coisas que ele definiu a si mesmo". (1994, p.136).

\subsection{Observações desde Crary e Berardi}

A leitura dos textos de Jonathan Crary é responsável pela condução deste trabalho ao que ele é hoje. Trata-se de três textos (1990, 2013 e 2014), embora o segundo livro que fala das suspensões da percepção, tenha uma participação menos ativa. $E$ isto não se dá por nenhum outro motivo a não ser porque considero que merece uma leitura mais aprofundada para aproveitar os desdobramentos que oferece.

Em Técnicas do Observador ele fala sobre "a visão e sua construção histórica" (1990, p.11), trata da reorganização da visão no século 19 e traz para a 
pesquisa a noção de Observador e a formação do olhar a partir da mudança da pintura para os dispositivos pré-cinematográficos. É fundamental para o entendimento das alterações significativas no regime de percepção criado na sociedade industrial. $\mathrm{O}$ autor dialoga amplamente com Foucault e Benjamin que trazem conceitos tão caros à pesquisa.

Em Suspenções da Percepção fala que "a modernidade visual tomou forma dentro de um campo já reconfigurado de técnicas e discursos sobre a visualidade de um sujeito observador". (2013, p.30) Ele desenvolve o problema da atenção para

\footnotetext{
"questionar a pertinência de isolar a contemplação ou absorção esteticamente determinada. O campo das práticas da atenção oferece uma superfície única heterogênea onde objetos discursivos, práticas materiais e artefatos de representação não ocupam estratos qualitativamente diferentes, mas estão envolvidos por igual na produção de efeitos de poder e de novos tipos de subjetividade." (Idem, pp. 30-31)
}

Embora neste trabalho Crary trate da observação de pinturas, a atenção é considerada como atividade inserida na dinâmica da subjetividade e também essencial para a compreensão das alterações no regime de percepção.

Para trabalhar a ideia da conexão permanente, Crary transita por diversos campos científicos, explica como as novas tecnologias e seus mecanismos de controle interferem diretamente na ação humana e em nossa sociabilidade. Em sua obra mais recente e utilizada neste trabalho, há uma crítica à hegemonia da mercantilização e do consumo em massa de bens não-duráveis e à emergência da globalização. O termo 24/7 advém de conceitos neoliberais numa sociedade conectada em redes de comunicação, produção e monetização que atuam de forma ininterrupta e dependem cada vez mais de suportes eletrônicos e da Internet.

Sob esta ótica de Crary defende que o sono seria a última fronteira a ser ultrapassada para um desligamento da conexão permanente em que a sociedade contemporânea está envolvida. Não deixa de ter algo de rebeldia nesta maneira de dormir e 'se ausentar', silenciar, bem como e por mais paradoxal que possa parecer, é também uma forma de despertar para a vida e para a subjetividade praticamente impossível de ser acessada na sociedade de demandas constantes da qual o Usuário faz parte. 
Assim como Crary defende o sono, Berardi ${ }^{4}$ critica a forma como vivemos hoje e a maneira como o sujeito se relaciona com o campo do trabalho. Para ele, somos de modo geral, maltratados socialmente dentro um contexto do capitalismo neoliberal e dos modelos que o trabalho assumiu na sociedade contemporânea. Berardi defende o 'desenredamento' dos fluxos informativos acelerados a que estamos expostos por meio das novas tecnologias e que influenciam em nossa sensibilidade e processos cognitivos.

Berardi não é, de maneira nenhuma, alheio à tecnologia e à comunicação midiática, coloca que o diagnóstico nada otimista do cineasta e escritor Pier Paolo Pasolini nos anos de 1970 foi profético quando disse que havia uma mudança nas sensibilidades na sociedade italiana de então que acontecia em consequência de um "novo fascismo" imposto pela globalização, como se refere Juan Iñigo Ibáñez na entrevista com Berardi. Para o entrevistador, Pasolini

\begin{abstract}
"acreditava que esse processo estava criando - fundamentalmente por meio do influxo semiótico da publicidade e da televisão - uma nova 'espécie' de jovens burgueses, que chamou de 'os sem futuro': jovens com uma acentuada 'tendência à infelicidade', com pouca ou nenhuma raiz cultural ou territorial, e que estavam assimilando, sem muita distinção de classe, os valores, a estética e o estilo de vida promovidos pelos novos 'tempos do consumo'. Quarenta anos depois, outro inquieto intelectual de Bolonha - o filósofo e teórico dos meios de comunicação Franco 'Bifo' Berardi - acha que o sombrio diagnóstico de Pasolini tornou-se profético, diante da situação de 'precariedade existencial' e aumento de transtornos mentais que as mudanças neoliberais provocaram." ${ }^{5}$
\end{abstract}

Sob um determinado ponto de vista, a precarização e a fractalização do trabalho provocaram uma profunda mutação na esfera psicológica (psychosphere), o que é visível como aumento das psicopatologias como sintomas de stress póstraumático, autismo, pânico e desordem do déficit de atenção. As mudanças que acontecem atualmente na sensibilidade estética e emocional do sujeito, mudanças que constituem o resultado da captura os recursos mais profundos do processo

\footnotetext{
${ }^{4}$ Em dois trabalhos: And - Phenomenology of the End (2015) e The Soul at Work - From Alienation to Authonomy (2009). Ambos sem tradução no Brasil.

${ }^{5}$ Disponível em:

http://www.ihu.unisinos.br/eventos/564429-neoliberalismo-assexualidade-e-desejo-de-morte-emedicao

Último acesso em 11 de março de 2018.
} 
subjetivo realizada como semiocapitalismo: a experiência de tempo, a sensibilidade, a maneira como nos relacionamos e a habilidade de imaginar um futuro fazem parte da pesquisa e da crítica de Berardi (2015).

Desenhando uma genealogia estética da globalização capitalista, aponta que chegamos a um ponto de tal complexidade no fluxo semiótico do capital que não conseguimos mais processar o excesso de informação no qual estamos envolvidos, numa sociedade a qual não podemos mais dizer 'não'. A partir do ponto de vista de um comportamento social baseado em padrões de interação impossíveis de escapar, codificados por máquinas de linguagem técnica, smartphones, múltiplas telas e todos os dispositivos que baseiam a relação em pressupostos sensoriais e emocionais, são dispositivos que, na visão dele destroem nossa sensibilidade por nos submeter ao estresse da competição e da aceleração.

Ao contrário de Agamben, ele coloca claramente o seu ceticismo com as relações entre o sujeito e os dispositivos tecnológicos, tanto Crary quanto Berardi possuem visões bastante críticas e, por vezes, sombrias sobre as atuais configurações dos relacionamentos humanos e dos modelos de trabalho, mas que sempre apontam um universo de opções e soluções. Não há neles qualquer tecnofobia aparente, mas uma visão de mundo e de um sujeito que se tornou dependente da tecnologia para existir e pertencer e que precisa olhar criticamente para este universo para rever conceitos e significados.

\subsection{A experiência do acontecimento}

Ao estabelecer uma existência conectada, o Usuário está em movimento como o Flanêur insone de Crary, descortinando a técnica como em Heidegger, submetido a um acordo com o poder institucional foucaultiano e uma atenção existencial constante como em Berardi, e constantemente em comunicação ao vivo, num durante eterno como em Marcondes Filho. Este é o sujeito comunicacional híbrido tratado na pesquisa.

Quando o fenômeno da comunicação é visto pelos ângulos humano, medial e tecnológico dentro da perspectiva da teoria do Metáporo, introduz à pesquisa uma noção de tempo presente na comunicação que, entre tantas ideias, mostra como o 
homem tecnológico se presentifica na sociedade da informação e busca novos significados para o seu universo. Marcondes Filho (2013) diz que

\begin{abstract}
"a captura de informações e a comunicação irão ocorrer exatamente quando damos alguma importância a algo que vemos, ouvimos, percebemos do ambiente externo, ou seja, quando efetivamente fazemos uma seleção, uma triagem em que separamos algo em que queremos nos envolver, seja por vontade própria, seja por alguma armadilha que nos faça voltar à coisa mesmo sem intenção" (2013, p. 22).
\end{abstract}

Ele busca sentido para a comunicação no tempo presente, no momento durante $\mathrm{o}$ ato comunicacional. Esta teoria entra em consonância e agrega novos conceitos à ideia de que o Usuário vive um Metáporo da comunicação, porque sua relação é com o presente.

A ideia de 'acontecimento comunicacional' utilizada aqui também vem da teoria de Marcondes Filho que busca uma compreensão da Comunicação pelo fato do que ela é, pelo ato de se comunicar, o que dialoga de perto com este trabalho, porque aqui também se parte de atos de comunicação para pensar sujeito e sua relação econômicas e sociais. Marcondes Filho recorre à filosofia para uma compreensão mais profunda desta ideia. Fala de Levinas quando trata do devir e diz que a surpresa reservada pelo devir também constitui um ato de comunicação e quando o filósofo diz que a comunicação é um acontecimento que "cai sobre nós" (in MARCONDES FILHO, 2017, p.20). No entanto, o devir de Levinas não é o mesmo de Deleuze e Guattari em Mil Platôs: "situação em que a vespa rodeia a orquídea e, neste rodear, ambas incorporam algo, uma da outra, sem se tornarem efetivamente uma a outra". (Idem, p. 21) E Marcondes Filho prefere dizer que

“o falar simplesmente é uma emanação do meu estatuto humano. Eu não
apenas falo. Eu emito sons que remetem a situações outras, não presentes,
que evocam imaginações. É essa a diferença de Émile Benveniste fala
quando se refere ao voo das abelhas e sua complexidade informativa: elas
não constroem uma mensagem a partir de outra mensagem. Isso só os
humanos fazem. Mas, quando eu falo a outra pessoa sobre uma notícia que
eu ouvi, eu tampouco estou repassando algo, no sentido de pôr aquilo na
cabeça do outro, diretamente (como sugere a comunicação na física, na
química, na biologia). Eu falo, pronuncio frases, gesticulo, movo meu corpo,
dou entonações, mas tudo isso, para esse outro que me ouve, funciona como
'sinalização externa', que ele irá decodificar à sua maneira. Eu não posso
interferir na forma como o outro me ouve. Isso cabe a ele. Na cabeça desse
outro, a triste notícia que eu comentei ganhará colorações próprias, pessoais,
às vezes diferentes, mesmo opostas, à forma como eu verbalizei aquilo que
ouvi, li, vi, senti, percebi. O processo da comunicação não é um processo de
fusão. O que me marcou na notícia não irá necessariamente marcar o outro 
e, se marcar, será diferente da forma como me marcou. Não se comunica uma notícia. Vivencia-se uma notícia diferentemente. Por isso, comunicação é um acontecimento pessoal, singular, de mim mesmo, quase uma revelação, aquela ação divina que passa ao homem os desígnios de Deus e as "verdades" que estes envolvem". (2017, pp.25-26) ${ }^{6}$

O comportamento desse sujeito está diretamente ligada à percepção de como ele se maifesta durante um acontecimento comunicacional. Embora em alguns textos trate mais especificamente de Jornalismo, as noções trazidas por ele estabelecem um diálogo entre a relação do sujeito Usuário com os dispositivos de acesso à internet e a relação de valor estabelecida por estes meios.

\begin{abstract}
A explicação, aqui, é a de que a linguagem, que na "era dos meios" era representacional, mediadora, assume agora a centralidade, e o jornalismo, segundo ele, constitui-se agora como "feixe de relações". O que era central, monopolista, torna-se múltiplo, plural. Não fica claro em que "midiatização" difere da mediatização, visto que se trata apenas de um deslocamento do eixo de poder, de um para vários, sendo que as tecnologias permanecem as mesmas, agora mais modernizadas, mas para ambos os lados. Efetivamente, não há a mudança proposta. Fausto Neto diz que agora não são mais os valores-notícia nem as rotinas que definem os acontecimentos, mas são "vários atores e instituições não jornalísticas". (MARCONDES FILHO, 2015, p.140 $)^{7}$
\end{abstract}

A construção do sujeito midiático Observador passa pelos dispositivos do précinema, a transformação no Espectador passivo do século 20 - aquele que dedicou o seu tempo a assistir horas e horas diárias de televisão e que moldou uma agenda doméstica em torno de uma grade de programação televisiva - e que se torna o consumidor de produtos midiáticos através da Internet e das redes sociais no século 21. O Usuário se mostra como esse sujeito Observador de um passado recente construído todos os dias e em movimento, porque dispõe de tecnologias e mídias para tanto. Aquele horizonte fascinante que se abria nos 1800 é semelhante em inovação, deslumbramento e uso da atenção ao que se abre agora nas primeiras décadas dos 2000.

\footnotetext{
${ }^{6}$ Revista Paulus. Disponível em: http://fapcom.edu.br/revista-paulus/index.php/revista-paulus/article/view/5/5 Último acesso em 19 de março de 2018.

${ }^{7}$ Rev. Famecos (Online). Porto Alegre, v. 22, n. 2, abril, maio e junho de 2015. Disponível em: http://revistaseletronicas.pucrs.br/ojs/index.php/revistafamecos/article/view/20143/13214 Último acesso em 19 de março de 2018.
} 
Dentro da perspectiva de conhecer melhor este sujeito, tem-se a impressão de que ele deixa de ser passivo por dois motivos: porque não depende de uma grade de programação televisiva, por exemplo, e assiste os produtos quando, como e onde quiser e, em tese, dispõe do próprio tempo com muito mais liberdade. $\mathrm{E}$ também porque parece ter se transformado num produtor de informação atuante nas redes sociais em busca de visibilidade e de um eterno pertencimento.

\subsection{Técnicas do Observador}

Para que aconteça o estudo do Usuário, é necessário que ele seja visto como um Espectador e Observador 'ao vivo'. A sua ação é parte do momento presente do ato comunicacional em que tudo acontece, numa chave de transformação permanente do que o Usuário viu, postou, divulgou, projetou e emitiu ao vivo na rede.

A ação do sujeito filosófico cultural que se monta aos poucos passa pela ideia de que ele faz um circuito completo: vê e reflete o seu presente durante o momento da comunicação. Diante da desocultação da técnica, da tecnologia dentro da sociedade que auxilia na construção de redes sociais e as relações geradas devido ao seu uso com as questões relacionadas à visibilidade em termos de público e privado da sociedade tecida pela comunicação (MIĖGE, 2009), entende-se que o Usuário pode estar num patamar semelhante ao do Observador quando ambos tem contato com o novo da tecnologia, o olhar é provocado a se transformar e a comunicação estabelece novos paradigmas de relacionamento. A tecnologia de então era a dos dispositivos pré-cinematográficos e a de hoje com as infinitas possiblidades da internet, dispositivos móveis e redes sociais.

O que vemos hoje é uma alteração nos modos e ver proporcionada pela internet e os dispositivos de acesso, principalmente os móveis. E que alteram também o local do sujeito diante da emissão. Assim como a Câmera Obscura nos séculos 16 e 17, e depois com dispositivos como o Fenacistoscópio, por exemplo, que conduziam o sujeito a observar as imagens em movimento numa experiência individual ou coletiva mas sempre como Observador perante o dispositivo assistindo passivamente a uma emissão, sem que fosse solicitada uma interação física a não ser a do olhar e da percepção. 
No entanto, esta separação do corpo físico não se dá quando o objeto é o Estereoscópio que solicita do Observador um papel no processo de significação. Além de ter modificado a perspectiva renascentista que implicava num espaço homogêneo e contínuo, percebe-se que passa a ser "um campo constituído de elementos desnudificados e simplesmente agregados" como sugere Machado ${ }^{8} \mathrm{e}$ que não recebe um grande destaque no livro de Crary. Os dispositivos de visualização do século 19 reposicionam o Observador. Para Machado, "a visão se materializa e se torna ela própria também visível, além de se mostrar inseparável das possibilidades e aptidões de um sujeito Observador. O corpo que observa tornase ele próprio um componente das novas máquinas" (MACHADO, 2007, p.176)

Assim como a Câmara Obscura foi um paradigma de modos de visualizar do século 15 ao 18, é importante entender a função o Estereoscópio neste momento para que possamos fazer a relação com um ponto de vista da contemporaneidade. O Estereoscópio é um aparelho produtor de visão binocular tridimensional e colabora na transformação do estatuto do Observador dando-lhe uma nova "forma". Para Machado, o dispositivo em si não tem esse poder, mas atua como um "ponto de inserção onde os discursos filosóficos, científicos e estéticos em circulação no começo do século 19 se encontram com as forças socioeconômicas, institucionais e tecnológicas do mesmo período". (Idem, p.176)

O Estereoscópio no século 19 colaborou nas transformações das capacidades cognitivas e psicológicas, reposicionando o Observador num momento de "reconsideração do papel do indivíduo como Observador" (Idem). Para Crary a revolução na natureza e na função do signo no século 19 "não pode ser pensada independentemente deste processo de reconstrução do sujeito". (CRARY, 1990, p. 17) Portanto, é possível pensar que a natureza e a função do signo no processo de reconstrução do sujeito passa pelas práticas do sujeito que colaboram no processo de ressignificação. Crary considera a estereoscopia a mais importante forma de iconografia do século 19 , seguida de perto pelas sínteses pré-cinematográficas do movimento.

Ao longo do século 20 o Estereoscópio ${ }^{9}$ ganhou versões transformadas em brinquedos ${ }^{10} \mathrm{e}$ atualmente tem a versão de realidade virtual com o uso dos telefones

\footnotetext{
${ }^{8}$ Texto Técnicas do Observador (2007) sobre o livro homônimo de Crary.

9 "Com o uso da estereoscopia, a ilusão de profundidade é criada, apresentando mais um elemento de imersão para a realidade virtual. Para que isso acontece, duas imagens diferentes são geradas,
} 
celular acoplados aos óculos VR e com experiências em 360 graus. ${ }^{11}$ Hoje e cada vez mais, o Observador, agora transformado em Usuário, se torna o componente das máquinas contemporâneas porque se dedica fisicamente e também a sua atenção a elas. Os dispositivos contemporâneos como computadores, tablets e telefones celular também são "pontos de inserção" dos discursos com as forças econômicas e institucionais e com as tecnologias atuais.

Os dispositivos de visualização de pares de fotografias que proporcionavam a experiência em 3D do século 20 e os de Realidade Virtual do 21 , atuam numa mesma frequência de relação como sujeito Observador/Usuário que o Estereoscópio de quase dois séculos atrás: uma experiência individual e solitária quase como se fosse um voyeur a espiar no buraco da fechadura. Assim como a perspectiva renascentista determinava o ponto de vista e a leitura a partir de um espaço homogêneo e absoluto da pintura que se estabelece no ambiente para ser observada, o dispositivo eletrônico do 21 sugere um ponto de vista sempre móvel e provisório.

Machado vê a imagem do computador como uma meta-imagem sempre possível de ser modificada e, portanto, dona de uma transitoriedade impossível de existir no Renascimento das pinturas absolutas em sua existência concreta e irreprodutível. Com a reprodutibilidade técnica ${ }^{12}$ eletrônica e dos sistemas digitais ele coloca que "a determinação do ponto de vista sob o qual será dada a imagem é a última coisa que se faz quando se faz. Nem se trata também de um ponto de vista no sentido clássico, pois ele é sempre móvel, provisório e infinitamente modificável". (MACHADO, 2007, p. 183) Ele contrapõe este ponto de vista ao do filme ou à fotografia que segundo ele exigiriam sempre uma decisão antes de serem executados. Embora concorde com a transitoriedade da imagem e de pontos de

uma para cada olho. O efeito consiste na interpretação do cérebro de que as duas imagens na realidade são uma só".

Óculos desenvolvidos mais recentemente possuem um visor 3D que tem a capacidade de interagir em sincronia com o movimento da cabeça do Usuário proporcionando uma experiência mais próxima do real.

Disponível em: http://www.techtudo.com.br/noticias/noticia/2015/09/o-que-e-realidade-virtual-entendamelhor-como-funciona-a-tecnologia.html

Último acesso em 19 de março de 2018.

${ }^{10}$ Disponível em: http://www.albertodesampaio.com.br/fotografias-em-3d-no-seculo-xix-e-xx/ Último acesso em 19 de março de 2018.

${ }_{11}$ Disponível em: http://www.view-master.com/en-us/index.html\#

Último acesso em 19 de março de 2018.

12 Walter Benjamin (2018. Original de 1955). 
vista diversos para ela, não acredito necessariamente nesta falta de determinação de ponto de vista para a imagem eletrônica. Ela também está rodeada de intenções e projetos que 'pretendem' comunicar através dela. Portanto, sim, o ponto de vista pode não ser clássico, mas há que se levar em conta que há sempre uma ideia e um texto a ser revelados por ela, mesmo que transitórios.

Por isso mesmo, o que se segue no texto de Machado é relevante quando diz que

\begin{abstract}
"num videogame, o ponto de vista é, em geral, móvel e intercambiável. A qualquer momento ele pode ser modificado, de modo que permita rever uma mesma cena de outro ponto de vista. Quer dizer: numa estrutura móvel como essa, essencialmente permutativa e manipulável, o ponto de vista já não pode ser restituído como a condição fundante do discurso figurativo". (Idem, p. 184)
\end{abstract}

Ele destaca o ressurgimento da estereoscopia nos dispositivos de realidade virtual e critica a falta dessa percepção em Crary. Ainda sugere o retorno intenso desta carga simbólica nos "aparatos digitais de imersão". Os óculos de realidade virtual e qualquer outro dispositivo que possa ser acoplados ao corpo do sujeito comunicacional mostra que está

\begin{abstract}
"ligado umbilicalmente ao computador, nos dispositivos de realidade virtual, e com o corpo literalmente coberto de próteses, encarna até as últimas consequências esse novo sujeito alinhado às máquinas, colocado a operar como uma de suas partes e cujas atividades dependem de processos automáticos de codificação e regulamentação. (...) o que sucede com o surgimento do computador é que a estereoscopia finalmente se liberta da servidão fotográfica. Com o surgimento da imagem digital, é possível conceber a estereoscopia no verdadeiro sentido do que fala Crary, ou seja, fora da ilusão figurativa e fora do modelo perceptivo da câmara obscura". (Idem, p. 184)
\end{abstract}

Do 19 para o 20 o Espectador da Fotografia, do Cinema e da Televisão se mostra passivo diante das mídias imagéticas que Ihe trazem o espetáculo. Ele cede lugar para uma forma comportamental de produtor ativo de informação proveniente da atuação do Usuário que vemos se estabelecer nas sociedades midiáticas contemporâneas. Seja porque ele pode assistir aos produtos audiovisuais em telas simultâneas de mídias móveis e fixas com uma diversidade de possibilidades, se desprendendo totalmente da necessidade de estar sentado em frente a um monitor de TV. Seja porque ele está em movimento pelo ambiente que frequenta - cidade, 
trabalho, escola, família, etc. - e tem com esse ambiente um ato comunicacional acontecendo ao vivo num tempo presente, retirando daí observações necessárias para as postagens na rede e a visibilidade pretendida.

Com o Usuário, tudo acontece numa frequência ao vivo, no "durante da comunicação". Este novo sujeito não dispõe de um tempo de reflexão muito longo ou o mesmo tempo que o Observador e o Espectador tinham ao seu dispor. O seu tempo é outro: de um imediatismo e de uma urgência da manifestação em sintonia com o real. Tal como um Flâneur, o Usuário reflete sobre o seu ambiente e momento. Às vezes apenas registrando o agora, mas sendo assim mesmo um tipo de reflexo/registro, numa frequência diferente de um hábito anterior quando todas as manifestações haviam sempre de passar pela produção da mídia convencional televisiva, radiofônica ou impressa. Hoje não mais. O dispositivo é um tablet, celular, computador; a mídia é a Internet, e o recurso é o aplicativo através do qual ele vai postar o seu registro. Se não for por condições econômicas e de infraestrutura que podem deixar o Usuário de fora dessa história, nada mais o detém, ele não depende de muitas outras coisas para estar na rede e se tornar visível. Intuitivamente carrega consigo toda a bagagem histórica, comunicacional e afetiva deste período que o trouxe até aqui. Tem o novo nas mãos, como o Observador e o Espectador o tinham antes dele.

As redes sociais, em si, funcionam de forma gratuita como Facebook, Twitter, Instagram, Snapchat, Whats $A p p^{13}$, e são exemplos utilizados em diversos momentos do trabalho por serem possuírem apelo mundial e estarem entre as mais conhecidas no momento desta pesquisa. O Youtube ${ }^{14}$, com mais de um bilhão e meio de Usuários por dia, não está incluído no perfil de rede social porque tem o foco de ser

\footnotetext{
${ }^{13}$ Até o momento, mas inúmeras outras devem surgir até o encerramento deste texto. Twitter tem pelos menos 500 milhões de Usuários ativos diariamente. A rede de contatos pessoas do Facebook conta com mais de dois bilhões de Usuários dários. O Instagram chega nos 800 milhões de Usuários diários em compartilhamento de imagens. Snapchat - lançado em 2011 e com mais de 200 milhões de Usuários diários que postam cerca de 2 bilhões de histórias por dia visualizadas em todo o planeta. E o WhatsApp com 1.3 bilhão de Usuários diários enviando mensagens instantâneas individualmente ou me grupos na forma de texto, foto e vídeo.

Disponivel em: https://www.statista.com/statistics/272014/global-social-networks-ranked-by-numberof-users/

Acesso em 19 de março de 2018.

${ }^{14} \mathrm{O}$ termo vem do Inglês you que significa você e tube que significa tubo, ou canal, mas é usado na gíria para designar televisão. E Broadcast Yourself (numa tradução livre: Transmita-se) é o slogan, ou a frase que move as ações no Youtube.
} 
um site de compartilhamento de vídeos enviados e/ou feitos pelos Usuários do que propriamente uma rede social. Embora não esteja fora de consideração quando se trata de produzir material na rede.

A mídia móvel possibilita o movimento, a ação do Usuário na cidade e a interação dele com outros ambientes não-virtuais de maneira que as informações e experiências desses lugares sejam intercambiáveis. É de se esperar que uma experiência do ambiente de realidade não-virtual tenha uma comunicação imediata com os ambientes virtuais e redes de comunicação interpessoal, ou redes sociais.

Imediatamente e inclusive durante a experiência o Usuário tende a postar alguma informação em foto, vídeo ou texto que reflita o momento vivido para que seja compartilhado com outros Usuários.

O lugar onde o Usuário está, no que diz respeito distância geográfica, já não se torna importante. Talvez a importância das distâncias geográficas tornem o contato ainda mais atraente na medida em que aumentam ao mesmo tempo em que são tão fáceis de serem vencidas pela aproximação virtual. A sensação do Usuário de receber uma visibilidade em qualquer lugar do planeta aproxima e se coloca como um ponto de atração determinante para quem participa seja postando, visualizando ou interagindo com os posts. O que parece importante é ter a comunidade que dá visibilidade às ações na rede e que constituem um dos principais modelos de publicização social atualmente.

Quando antes havia a passividade, hoje há atividade em relação ao presente da comunicação enquanto ela acontece. O Espectador parece ter sido um intermediário necessário entre eles, a contribuição essencial para a transformação. Portanto, há um estímulo que conduz à percepção de que as três 'personas' comunicacionais venham a se tornar o que se pode chamar de um 'sujeito fundante' do sujeito comunicacional contemporâneo. Estariam presentes em traços como o durante do ato comunicacional no contato com a informação.

A ideia de visibilidade parece funcionar como elemento estruturante da mudança que se dá cotidianamente no acontecimento comunicacional. Há a uma mudança inevitável de cenário no comportamento deste sujeito midiático: há o Observador que olha, e o Usuário que é olhado e entre os dois o Espectador que serve de ponte evolutiva. 
É provável que alguns comportamentos apontem para um Usuário que ainda atua num campo muito semelhante ao do Espectador, ligado ao hábito de assistir TV ainda que hoje ele tenha acesso à TV ou aos produtos audiovisuais produzidos para TV praticamente de qualquer lugar onde esteja, através do uso de mídias móveis e pela Internet. Mesmo assim, parece possível encontrar esse Espectador que não se desvencilhou completamente da programação convencional e ainda não pensa 0 meio audiovisual móvel como uma possibilidade de montar a sua própria grade. $\mathrm{O}$ Usuário se coloca como um Observador que saiu da Modernidade para entrar na contemporaneidade e continua a ver TV, o que as emissoras de TV oferecem em sua grade de programação ou menu de opções, como preferir o leitor.

Nos 1800 as noções de óptica e de retenção da imagem na retina eram estudos daquele momento histórico e os conhecimentos adquiridos através de noções empíricas e posteriormente científicas com o auxílio de dispositivos para tal. Com a Fotografia e o Cinema, mudaram-se radicalmente as formas de ver e o desenvolvimento do século 20 trouxe os meios de comunicação de massa que são produto único da tecnologia como o Rádio e a Televisão. O 'áudio/visual' que vinha se transformando com o Cinema Silencioso e depois com o Cinema Falado ganha um caráter de entretenimento acessível e doméstico com a chegada da TV.

A programação é implantada, sofre modificações e cresce em número de horas de exibição à medida que a indústria televisiva ganha corpo e diversificação até chegar as 24 horas diárias ininterruptas que permitem ao Espectador a experiência de um fluxo contínuo de produtos audiovisuais seja na verticalidade da grade de programação da TV aberta, seja na horizontalidade a TV por assinatura. A TV passa a atender modelos de negócio que vinculam espaços comercializados às produções.

Mas, de modo geral e independentemente da existência ou não do controle remoto ou dos modos de gravação que passaram a existir a partir da década de 1980, a Televisão se caracteriza por exibir uma programação variada, pronta, intercalada por produtos ao vivo e pré-gravados na qual o Espectador não pode interferir nas decisões de produção do fazer televisivo ${ }^{15}$, que não se repete no caso

\footnotetext{
${ }^{15} \mathrm{~A}$ interferência que pode acontecer em qualquer nível de conteúdo e programação, neste momento ainda acontece a partir do ponto de vista de quem detém os meios de produção e não do Espectador. Este cenário se transforma aos poucos com a interação de espectadores em alguns produtos e projetos das redes de televisão.
} 
da TV aberta e que tem reprises agendadas no caso da TV por assinatura bastando se acomodar em frente ao aparelho e assistir à emissão das produções audiovisuais.

Nos anos 2000 o olhar se move. A construção do novo Espectador, a determinação do seu tempo e as várias telas com novas formas de visualizar os produtos, porém com outra divisão/percepção do tempo ressignificam o Espectador. O meio de comunicação de massa migra da TV para a Internet e o acesso à informação e aos produtos audiovisuais acontecem em movimento com as diversas telas móveis.

A exemplo de um Flâneur de Walter Benjamin, o Usuário acontece na mobilidade. Ele se move pela cidade/local em movimento ao mesmo tempo em que navega pelo mundo virtual e absorve o local por onde passa ao mesmo tempo em que consome os produtos que estão acessíveis no seu dispositivo de mídia. Na rede ele se insere num contexto de produção de informação com postagens, textos e vídeos e é visível em tempo integral alimentando constantemente a rede com material produzido por ele. Convive num ambiente onde tudo é visível, fragmentado, disperso e acessível. Onde grande parte da produção audiovisual se mantém sendo feita por grandes conglomerados de comunicação e, portanto, ainda é imposta sob certos aspectos. Ele posta reações e recebe respostas imediatas e todo o conteúdo é público e publicizado. Traça diariamente um perfil de suas preferências, reage ao que foi assistido produz novos dados através das postagens nos sites, blogs, páginas e redes sociais, e revela perfis do novo produtor: quais os locais que frequenta, o que deseja, como se comporta, o que consome, quais caminhos segue. Tal comportamento também se dá na chave da visibilidade e do pertencimento a um determinado grupo. Por isso, as reações tratam de interações e de compartilhamento no que parecem ser novas modalidades de comunicação ativadas pelo senso de comunidade e de visibilidade do Usuário.

Os capítulos seguintes: Da percepção ao Usuário contemporâneo; Sujeito/Usuário: a busca da identidade na modernidade tardia; Usuário 'ao vivo' e Flanêur e dócil tentar dar conta desta perspectiva de demonstrar a reconfiguração contemporânea desses sujeitos. 
Capítulo 2

DA PERCEPÇÃO AO USUÁRIO CONTEMPORÂNEO 


\subsection{O Observador século 19 - a construção do olhar}

Observador é a denominação desenvolvida por Jonathan Crary para compreender um novo tipo de indivíduo no século 19 que se transforma em objeto de investigação e também em 'lugar' de conhecimento, um sujeito 'carregador' de cultura e informação ainda em estado inicial de determinados tipos de percepção. Por 'lugar' de conhecimento compreende-se que seja um sujeito acumulador de uma bagagem de cultura tecnológica ampliada a cada contato com novos dispositivos revelando novas maneiras de usos e comportamento sócio culturais criados a partir deste descortinar de modos de usar e de estar.

E este trabalho toma emprestado a figura e o conceito de Crary para entender a evolução da percepção e de como o Observador chegou aos anos 2000 com um cotidiano habitado pela informação compartilhada, pela produção de conteúdo e a participação ativa na Internet. Ele é um novo produtor que assiste TV de uma maneira diferente do Espectador mas que, de certa forma, mantém uma tradição ao assistir exatamente o que o que lhe é fornecido pela TV ou pela internet num menu de opções - seja a grade de programação ou o menu do serviço de assinatura agregando atualmente a característica de quem produz também um determinado conteúdo como fazem os blogueiros, vlogueiros e integrantes de redes sociais.

O Observador é uma figura da Modernidade e se constrói a partir do acesso à tecnologia que tem como ponto de partida a criação da criação da Câmera Escura. Dentro de uma visão histórica, a Câmara Escura colaborou para o estabelecimento de um olhar construído e desenvolvido pela tecnologia disponível. O Observador do século $19^{16}$ encontrou nela o dispositivo ideal para a construção de uma forma de ver, onde o olho "alardeia um mundo real" (CRARY, 1990, p.135) e delimita a uma técnica de racionalização da visão. Com a Câmara Escura, o olhar do sujeito passou a estar vinculado a um dispositivo que determinava uma maneira de ver e que colaborou na organização do conhecimento e do sujeito Observador e se tornou inseparável de uma metafísica da interioridade, inseparável "tanto para o Observador livre como para o aparato social". (Idem, p.45)

\footnotetext{
${ }^{16}$ Há relatos sobre a Câmara Escura desde o século 11 e ainda de que o filósofo grego Aristóteles a teria usado para observações astronômicas.
} 
Na Câmara Escura, a luz era projetada através de um orifício em uma superfície fotossensível. A imagem que se tinha entre as quatro paredes escuras era invertida em relação à imagem original. E quanto menor era o orifício, mais nítida era a imagem devido a menor dissolução da luz. Um meio que é absorvido e institucionalizado como uma maneira determinante das formas do ver e que no século 19 será desafiado e pelas novas tecnologias disponíveis com a criação da Fotografia e, posteriormente, do Cinema. Conectada a uma metafísica da interioridade tanto para o Observador livre como para o apartado social, a Câmara Escura é o que Gilles Deleuze chama de "assemblage", algo que é simultânea e inseparavelmente uma montagem como máquina e como enunciação". (Ibidem, p.37)

Talvez entender a formação do Observador pelo ponto de vista da Câmara Escura, seja pensar a partir de uma tradição monolítica, dentro de uma concepção incompatível com o "fluxo e centralidade de signos e mercadorias móveis de identidade óptica". (Ibidem, p.66) E é necessário aqui refletir sobre esse sujeito como o futuro consumidor de cultura de massa que terá a Televisão e mais tarde a Internet.

Como parte de um reposicionamento do sujeito que ocorre com a mudança de fluxo de signos e sua ressignificação social, Observadores passaram a ser Espectadores na Sociedade do Espetáculo criada a partir da ideia do entretenimento maciço. O Fenacistoscópio ${ }^{17}$ se mostrou uma plataforma eficiente e um dos primeiros dispositivos para visualizar a imagem em movimento de que se tem notícia. Ocupa um lugar de destaque dentro da história do pré-Cinema. Na análise de Crary, as criações dessa época antecedem a criação da Fotografia mas, no entanto, atuam numa frequência referencial fotográfica porque exigem procedimentos da mesma área e "o desenvolvimento de técnicas de produção em série. Eles dependeram inextricavelmente de um novo ordenamento do conhecimento sobre o corpo e da relação constitutiva desse saber com o poder social”. (Idem, p.25)

\footnotetext{
${ }^{17}$ Criado em 1829 por Joseph Plateau dentro da linha de estudos empíricos da pós-imagem na retina, é composto de vários desenhos do mesmo objeto colocado em posições diferentes e sobre uma placa lisa e circular. Quando a placa gira em frente a um espelho, o Observador tem a ilusão de que a imagem está em movimento.
} 
O autor entende que os dispositivos colaboraram para uma "reconstrução do indivíduo como Observador, em algo calculável e padronizável, e da visão humana em algo mensurável e, portanto, intercambiável". (Idem). Nesta reflexão, percebe-se que este mesmo Observador no século 21 será um Usuário de informação de origens, gêneros e formatos diversos com grande ênfase em produtos audiovisuais em múltiplas telas e também um ator/produtor de novas formas de ver e de perceber o olhar.

Crary reitera que a padronização das imagens visuais no século 19 não deve ser vista simplesmente como parte "das novas formas de reprodutibilidade técnica, mas em relação a um processo mais amplo de normatização e sujeição do Observador." (Idem, p.26). Por isso diz que uma revolução na natureza e função dos signos no século 19 passa obrigatoriamente pela reconstrução do sujeito. A percepção decorrente da técnica descortinada pela tecnologia que (HEIDEGGER, 2007) é a nova forma de percepção proporcionando uma reconstrução do indivíduo como Observador que participa da elaboração de uma visão normativa. (FOUCAULT, 1995)

Quando o Observador tem acesso à tecnologia de visualização como o Fenacistoscópio ou o Estereoscópio, por exemplo - descortina a técnica num ponto de ruptura paradigmático do olhar ${ }^{18}$ porque revela e apreende uma técnica que passa a ser um "meio e um fazer humano" e pode ser chamada de "determinação instrumental e antropológica da técnica". (HEIDEGGER, p. 376, 2007)

$O$ instrumental tecnológico que intermedia este contato e produz uma mediação para o olhar, pode ser compreendido como a tecnologia que deu luz a uma nova noção, trazendo à frente o que estava oculto para que se torne o meio e o modo através do qual o objeto se torna a essência desse entendimento. Então aqui a técnica não é, portanto, um mero meio. "É um modo de desabrigar" (HEIDEGGER, p. 380,2007$)$ porque se dá a conhecer. E quando produz pela técnica, transmite o que é poético. Para Heidegger

"armação significa a reunião daquele pôr que o homem põe, isto é, desafia para desocultar a realidade no modo do requerer enquanto subsistência.

\footnotetext{
${ }^{18} \mathrm{O}$ ocidente e as descobertas tecnológicas que modificaram as formas de ver proporcionaram ao mundo todo uma grande transformação no olhar. Mas, nesse caso, o olhar é o ocidental porque a pesquisa parte de teorias e observações de pensadores ocidentais sobre fenômenos que aconteceram a partir do ocidente.
} 
Armação significa o modo de desabrigar que impera na essência da técnica moderna e não é propriamente nada de técnico. Ao que é técnico pertence, em contrapartida, tudo o que conhecemos como sendo estruturas, camadas e suportes, e que são peças do que se denomina como sendo uma montagem". (HEIDEGGER, p. 385, 2007)

O Observador é ousado quando se presta ao desafio de desarmar o que é novo. Está no âmbito da "armação" porque ele atua dentro de uma descoberta ordenada e de um momento que, numa primeira fase, não pode ser percebido de outra maneira a não ser do modo como é indicado e com a finalidade para o qual foi criado. O enunciado da técnica se apresenta como uma forma libertadora e criativa, porém a liberdade domina o que é livre no sentido do que é focalizado como diz Heidegger. Portanto, o Observador olha a partir de uma técnica que lhe é fornecida para este fim, e sua liberdade de perceber e criar se dá a partir desse momento de desocultação da técnica.

Da mesma forma que o Observador do século 19, o Usuário do século 21 também é livre dentro do que é focalizado. Ele irá criar e sair do que foi estabelecido dentro de uma cultura de compartilhamento e participação e se terá a sensação de liberdade e de pertencimento ao funcionar dentro de um universo de opções em todos os momentos em que acessa o seu ambiente virtual.

O Observador/Espectador/Usuário desta reflexão é um indivíduo que se torna um sujeito essencialmente comunicacional - nos dois sentidos: de que está preso a alguém [N.A.: ou a à alguma coisa] pelo controle e dependência e preso à sua própria identidade por uma consciência e autoconhecimento. (FOUCAULT, 1995, p. 235) - Ele se constrói cultural e socialmente a partir do convívio cotidiano com as tecnologias de comunicação de massa e, portanto, a partir de um contrato afetivo estabelecido com as determinações trazidas pela tecnologia e as técnicas que desocultam o sujeito atuante e actante com nova formas de economia das relações de poder que ele também desoculta nesses ambientes. Neste sentido, o não humano pode ser chamado de mediador, à medida que estabelece a interação humana em todos os níveis sociais entre humanos e media a relação destes com outros não humanos.

Portanto, pode-se considerar que o Observador está submetido a uma normatização da visão que passa por uma reflexão sobre o poder, no sentido da parceria e da troca - principalmente quando num ambiente de Internet, onde há 
compartilhamento de informações e trabalho realizado para o interesse final de uma plataforma, dispositivo, site, aplicativo, por exemplo.

Foucault trata de relações de poder; de comunicação e de uma ideia posterior que são as capacidades objetivas. Na primeira há a relação da técnica finalizada, do trabalho e da transformação do real; já na segunda há a relação dos signos, da comunicação da reciprocidade e da fabricação do sentido; e na terceira "a dominação e dos meios de coação, de desigualdade e de ação dos homens sobre os homens". Devido a objetividade com que se relacionam com a reflexão desta pesquisa, tratamos de utilizar mais as duas primeiras do que da última. No entanto, sem descartá-la porque coexistem numa interdependência dentro de um entendimento de "disciplina"

\begin{abstract}
"e aquilo que se deve compreender por disciplinarização das sociedades, a partir do século XVII na Europa, não é, sem dúvida, que os indivíduos que dela fazem parte se tornem cada vez mais obedientes, nem que elas todas comecem a se parecer com casernas, escolas ou prisões; mas que se tentou um ajuste cada vez mais controlado - cada vez mais racional e econômico - entre as atividades produtivas, as redes de comunicação e o jogo das relações de poder." (FOUCAULT, 1995, p. 242)
\end{abstract}

O poder designa relações entre parceiros "entendendo-se por isto não um sistema de jogo, mas apenas - e permanecendo, por enquanto, na maior generalidade - um conjunto de ações que se induzem e se respondem umas às outras". (FOUCAULT, 1995, p.240). As relações de poder e as relações de comunicação não são necessariamente diversas, mas se permeiam e se completam.

Dentro desse 'jogo' o poder se articula sobre as tentativas e os consentimentos das partes envolvidas. Não que tais tentativas tenham que ser necessariamente tentativas em si, mas podem ser movimentos de um lado e de outro com o objetivo de que a 'relação' ocorra, até mesmo com o desejo das partes para que um campo de ações e efeitos opere neste âmbito com os consentimentos e acordos entre as partes. Portanto, seguindo o raciocínio de Foucault "nenhum exercício de poder pode, sem dúvida, dispensar um ou outro e frequentemente os dois ao mesmo tempo". (Idem, p. 243)

$\mathrm{O}$ jogo do poder mencionado não se trata somente de quereres que estão em jogo, mas de qualquer querer numa situação de um acordo social. A normatização e normalização sociais já nem passam mais pelo questionamento do querer, mas 
simplesmente pela ação decorrente dele que pressupõe o conhecimento das regras e a concordância com elas. Por exemplo: o Usuário de Internet em qualquer dispositivo acessa um novo site mediante um cadastro. Ele sabe que as informações fornecidas estarão disponíveis para um tipo de prestação de serviço. Portanto, concorda em fornecer informações pessoais que servirão para que o site crie e desenvolva novos produtos, para que outros fornecedores conectados àquele inicial tenham acesso e possam oferecer serviços e produtos. No ato consentido há um acordo, um contrato. E mesmo que nem todo o universo daquele ambiente interesse ao Usuário, ele aceita para ter acesso e suprir os desejos e necessidades iniciais ou criadas e desenvolvidas a partir deste primeiro contato.

Não se pode compreender o sujeito comunicacional como alguém submetido a um sistema opressivo ou apenas injusto de comunicação. Antes de mais nada existe para ele um acordo do qual também interessa fazer parte. Quando o Observador aceita olhar através de um dispositivo que exibe imagens em movimento e se interessa ou pelo mecanismo em si, ou pelas imagens exibidas, ou pela narrativa, ou tudo junto; quando o Espectador senta em frente à TV para assistir um programa ele é parte de um acordo afetivo 'assinado' no momento do ato comunicacional. Este sujeito - ou o coletivo ao qual pertence - é livre e, enquanto livre, está em território favorável a desejos, condutas, reações e comportamentos. Para Foucault, só há poder diante da liberdade. Mas quando o que ocorre são relações "saturadas" como a escravidão quando não se pode escapar já há uma situação de opressão e de violência, o poder não pode ser exercido.

O poder que esta pesquisa quer entender em relação ao Observador passa pela condição essencial de liberdade para que exista um acordo de poder e não de "servidão", mas da estruturação de um campo de ação possível. ${ }^{19}$

\footnotetext{
${ }^{19}$ A análise foucaultiana das relações de poder estabelece pontos de apoio:

1. O sistema das diferenciações que permitem agir sobre a ação dos outros: diferenças jurídicas ou tradicionais de estatuto e de privilégio; diferenças econômicas na apropriação das riquezas e dos bens; diferenças de lugar nos processos de produção; diferenças linguísticas ou culturais; diferenças na habilidade e nas competências etc. Toda relação de poder opera diferenciações que são, pata ela, ao mesmo tempo, condições e efeitos.
}

2. O tipo de objetivos perseguidos por aqueles que agem sobre a ação dos outros: manutenção de privilégios. Acúmulo de lucros, operacionalidade da autoridade estatutária, exercício de uma função ou de uma profissão.

3. As modalidades instrumentais: de acordo com o fato de que o poder se exerce pela ameaça das armas, dos efeitos da palavra, através das disparidades econômicas. Por mecanismos mais ou 
Em toda relação de poder existe o uso de uma estratégia de poder, seja para atingir um objetivo, para obter uma vantagem sobre o outro ou no uso de meios para se alcançar a vitória. Para tanto, há o que Foucault chama de "soluções vencedoras" quando inexiste relação de poder sem resistência, "sem escapatória ou fuga, sem inversão eventual; toda relação de poder implica, então, pelo menos de modo virtual, uma estratégia de luta, sem que para tanto venham a se superpor, a perder sua especificidade e finalmente a se confundir". (FOUCAULT, 1995, p.248)

De maneira sutil, a dominação está em todas as tramas sociais numa condição global e "é uma situação estratégica mais ou menos adquirida e solidificada num conjunto histórico de longa data entre adversários". (FOUCAULT, 1995, p.249).

A normatização do olhar amplia um campo de ação com os dispositivos do século 20. O Cinema, e a Televisão ${ }^{20}$ exigem que o Espectador permaneça parado em frente ao dispositivo ou no ambiente especialmente criado para este fim tendo o contato com o produto emitido.

O Observador nasce sob a noção, ainda que primitiva, ou até mesmo inexistente em alguns ambientes, de que a partir do momento em que está submetido a um dispositivo de comunicação existe um acordo de poder e o sujeito aceita esse acordo diante do ato comunicacional passando a obter uma visão normatizada do universo que está ao alcance.

menos complexos de controle, por sistemas de vigilância, com ou sem arquivos. Segundo regras explícitas ou não, permanentes ou modificáveis, com ou sem dispositivos materiais etc.

4. As formas de institucionalização: estas podem misturar dispositivos tradicionais, estruturas jurídicas, fenômenos de hábito ou de moda (como vemos nas relações de poder que atravessam a instituição familiar); elas podem também ter a aparência de um dispositivo fechado sobre si mesmo com seus lugares específicos, seus regulamentos próprios, suas estruturas hierárquicas cuidadosamente traçadas, e uma relativa autonomia funcional (como nas instituições escolares ou militares); podem também formar sistemas muito complexos, dotados de aparelhos múltiplos, como no caso do Estado que tem por função constituir o invólucro geral, a instância de controle global, o princípio de regulação e, até certo ponto também, de distribuição de todas as relações de poder num conjunto social dado.

5. Os graus de racionalização: o funcionamento das relações de poder como ação sobre um campo de possibilidade pode ser mais ou menos elaborado em função da eficácia dos instrumentos e da certeza do resultado (maior ou menor refinamento tecnológico no exercício do poder) ou. ainda, em função do custo eventual (seja do "custo" econômico dos meios utilizados, ou do custo em termos de reação constituído pelas resistências encontradas). O exercício do poder não é um fato bruto, um dado institucional, nem uma estrutura que se mantém ou se quebra: ele se elabora, se transforma, se organiza, se dota de procedimentos mais ou menos ajustados. (FOUCAULT, 1995, pp. 246-47)

${ }^{20}$ O Rádio permite que o Espectador se movimente enquanto escuta o que é emitido. 


\subsection{O Espectador do século 21 - a domesticação do olhar}

Fruto de um desenvolvimento da pesquisa, busca tecnológica e ao mesmo tempo, um veículo/acontecimento determinante da cultura, a TV não é mero acaso. Trata-se de uma evolução que culmina com um determinado dispositivo tecnológico, uma percepção a partir de Williams que se aproxima também do pensamento de Lyotard quando entende que TV é um típico fruto da Modernidade.

A Pós-Modernidade como um estado da Cultura que colaborou na quebra de paradigmas modernos e no estabelecimento de uma nova ordem das coisas se legitima ao ultrapassar a Modernidade e determinar uma nova síntese do que está ao redor do ser humano. Esta condição Pós-Moderna é um "escrito de circunstâncias" (LYOTARD, 2000, p. xvii) e se instala após a Segunda Guerra com os avanços tecnológicos que passam a dar novos rumos para o estatuto do saber moderno. Lyotard traz a expressão - uma vez que o conhecimento se fragmenta por causa das questões informacionais - num novo cenário, ao qual denomina "pósmoderno". Até a chegada desta nova ordem de narrativas fragmentadas, tanto num contexto moderno quanto no pós-moderno, havia uma ordem no saber que estava mais ligada aos relatos setoriais. E neste rompimento da linguagem através da tecnologia há uma mudança de estatuto no saber, bem como nas esferas da cultura, do político e do social.

A partir de uma perspectiva de que o Espectador passou séculos assistindo a tudo passivamente: espetáculos de rua, cabarés, Teatro, Fotografia, pequenas sequências animadas nos dispositivos de imagem do século 19, e os do 20 como o Cinema e a Televisão, pode-se visualizá-lo como uma testemunha de seu tempo que vive cada fase no momento presente.

Dentro de uma ideia de Modernidade Líquida ${ }^{21}$, para utilizar um conceito desenvolvido por Zigmunt Bauman, mesmo que a TV do controle remoto ainda seja

\footnotetext{
${ }^{21}$ A liquidez da modernidade a qual Bauman se refere é justamente essa inconstância e incerteza que a falta de pontos de referência socialmente estabelecidos e generalizadores gera:

"São esses padrões, códigos e regras a que podíamos nos conformar, que podíamos selecionar como pontos estáveis de orientação e pelos quais podíamos nos deixar depois guiar, que estão cada vez mais em falta. Isso não quer dizer que nossos contemporâneos sejam livres para construir seu modo de vida a partir do zero e segundo sua vontade, ou que não sejam mais dependentes da sociedade para obter as plantas e os materiais de construção. Mas quer dizer que estamos passando de uma era de 'grupos de referência' predeterminados a uma outra de 'comparação universal', em
} 
uma realidade, ela se parece mais com a memória do início de uma nova era que dá origem a novos referenciais de fluxo de informação e de circulação de mercadorias comunicacionais. Para as gerações que assistem TV a partir desse contato, a tecnologia e a técnica estão introjetadas de tal forma que estabelecem um caráter de normalização e de normalidade e não parecem afetar em nada o cotidiano.

No entanto, a TV contribuiu de maneira revolucionária no que diz respeito ao desejo do telespectador, um sujeito tratado aqui de Espectador por ser considerado a evolução do Observador do século 19 que chega ao 20 como o Espectador do Cinema, Ouvinte do Rádio e telespectador da Televisão. É o Espectador, aquele que assiste tudo de maneira passiva até um determinado período nesta linha do tempo quando o cenário começa a mudar.

A Televisão é um dispositivo de tecnologia que permeia o século 20 responsável pelo consumo de informação em massa. É um intermediário técnico e tecnológico determinante para a carga cultural que o Espectador levará para o século 21. Ele só se configura como um Usuário porque teve um volume de conhecimento construído através do contato com os objetos configurados na linha do tempo do sujeito comunicacional, como os dispositivos descortinadores da construção deste sujeito, que ocupam um novo lugar social e na estrutura da cultura.

O Espectador atual não se manifesta como passivo porque interage constantemente com o meio emissor da informação, seja pelo simples fato de poder ligar ou desligar o aparelho - uma opção que sempre existiu - como também passou a usar o controle remoto de forma maciça a partir dos anos de $1980^{22}$, o que dá a ele a opção de trocar o canal da televisão e optar pelo produto deseja visualizar dentro das possibilidades oferecidas pela grade de programação.

\subsection{Televisão}

que o destino dos trabalhos de autoconstrução individual (...) não está dado de antemão, e tende a sofrer numerosa e profundas mudanças antes que esses trabalhos alcancem seu único fim genuíno: o fim da vida do indivíduo." (BAUMAN, 2001, p.14)

${ }_{22}$ Disponível em: http://www.newyorker.com/tech/elements/object-of-interest-remote-control Último acesso em 20/03/2018.

O controle remoto foi criado originalmente nos anos de 1950 pela fabricante de TVs norte-americanas Zenith. Mas foi nos anos de 1980 que realmente ganhou tecnologia, formato e pode oferecer o conforto ao Espectador. 
A sociedade industrial atraiu milhares de pessoas para as zonas urbanas, multiplicando rapidamente a população das cidades que se viram obrigadas a gerenciar uma densidade populacional inesperada e que teve de ser encarada como uma oportunidade e não como um fato. A partir da primeira metade do século 20 com o pós-Guerra, além do crescimento urbano, houve também um crescimento no nível educacional e um "forte aumento no número de pessoas pagas para pensar ou falar, mais do que para produzir ou transportar objetos", como mostra Clay Shirky. (2011, p. 9)

A Televisão que é colocada por ele como o elemento fundamental para a transição de um tipo de sociedade para outro, poder ser considerado um dos mais expressivos meios de comunicação de massa, e para quem o Espectador sempre foi um ser passivo, destinado a utilizar o seu tempo livre, o "excedente cognitivo" ao ambiente de trabalho transformando-o em momentos de lazer em família.

A TV aparece como uma abrangente e surpreendente novidade. Torna-se uma forma de suprir a necessidade de entretenimento de milhares de pessoas ao mesmo tempo, e a alternativa para as classes sociais que viviam em subúrbios longe da cidade e dos vizinhos - e não dispunham necessariamente de capital para adquirir bens culturais ou opções de entretenimento e informação que pudessem alcançá-los. Da mesma maneira que na periferia das grandes cidades atuais, as carências de opções culturais são mais raras do que nos centros onde circula maior fluxo de capital. O tempo livre em grande escala era algo com que as cidades não estavam preparadas para lidar e a TV veio suprir essas necessidades. Durante décadas e de maneira uniformizada foi a forma de entretenimento e informação de maior alcance no mundo a ponto de criar uma cultura própria, uma obrigação cotidiana que comprometeu grande parte ou todo o tempo livre dos cidadãos do mundo desenvolvido.

O Rádio também sempre ocupou um lugar de onipresença porque podia ser acessado mesmo durante outras atividades, mas a TV, para muita gente, virou a atividade. Shirky conclui que 
Sobre esta observação, nos deparamos com duas variáveis importantes: o fluxo televisivo, quando falaremos de programação e o controle remoto.

\subsection{Fluxo televisivo/grade de programação}

Para entender a construção do Espectador é importante prestar atenção na definição de 'sentido' que possui um contato de proximidade e interação com a grade de programação de televisão. Para tanto, são utilizadas algumas reflexões da pesquisa de Mestrado que trata das estratégias de programação de domingo das emissoras de TV aberta no Brasil. ${ }^{23} \mathrm{O}$ diálogo se estabelece na medida em que $\mathrm{O}$ sujeito comunicacional, o ato da comunicação e o dispositivo em questão com seus produtos audiovisuais são os mesmos estudados ali num recorte que traz uma visão do Espectador no contexto da segunda metade do século 20 quando a TV tem o seu auge.

Dentro da ideia de fluxo televisivo há três tipos, ou níveis descritos por Williams (1974): o fluxo como programação; o fluxo que acontece porque há produtos (mercadorias) entre e dentro dos produtos audiovisuais contemplados pela grade de programação; e um fluxo dentro desse movimento: a sucessão de palavras e imagens. (WILLIAMS, 1974, p.97)

Numa grade de programação televisiva, as interrupções seriam a característica mais visível de um processo de ver TV que em alguns níveis vem a definir a experiência. Embora seja importante lembrar que mesmo as interrupções constituem juntamente com os entrelaçamentos dos produtos e intervalos comerciais/institucionais um fluxo em si.

A organização da ordem de exibição dos produtos audiovisuais na televisão aconteceu a partir da necessidade de otimizar o tempo e, primeiro porque

\footnotetext{
${ }^{23}$ Um domingo qualquer - estratégias de grade de programação de televisão aberta no Brasil. Disponível em:

http://www.teses.usp.br/teses/disponiveis/27/27161/tde-27022014-164638/pt-br.php

Último acesso em 20/03/2018.

Informações apuradas para aquela pesquisa serão utilizadas nesta tanto pelo fato de se adaptarem ao assunto tratado, quanto pelo objeto de questionamento, além do que uma vez que em alguns momentos as mudanças que aconteceram com a Televisão já questionam algumas daquelas afirmações.
} 
tecnicamente houve aos poucos uma evolução e um aumento do tempo em que o sinal era emitido e que o público podia assistir televisão: passou de poucas horas por dia para períodos maiores até a TV 24 horas no ar como vemos hoje. E, depois, porque partiu-se de uma ideia inicial de uma lista de produtos a serem exibidos em determinados horários para tipos de público específicos.

No início das transmissões de televisão, quando os intervalos eram pontuados por sinais eletrônicos emitidos no vídeo gerando uma divisão entre os produtos que eram mostrados inicialmente inteiros, sem interrupções, já havia a ideia de programação e de exibição ainda com os produtos vistos como peças individuais, sem uma ligação necessária entre si. São o que Williams chama de "unidades de tempo" (WILLIAMS, 1974, p.89). No que diz respeito ao aspecto comercial, as TVs públicas não exibiam - e em alguns casos atuais não exibem comerciais nos intervalos porque estavam associadas às verbas públicas que não permitiam associação ao comercial privado. Enquanto que as emissoras e redes privadas sempre dependeram dos comerciais e dos patrocínios para continuar ativas como empresas. O que passa a mudar é quando os intervalos - onde antes não havia nada além de um sinal eletrônico - passam a exibir trailers, filmes institucionais da emissora e ou comerciais. É possível afirmar que é assim que a sequência de produtos audiovisuais passa a ser uma ideia de fluxo e quando o Espectador passa a "assistir TV" e não apenas a assistir um determinado produto na TV. Para Williams, a TV norte-americana já tinha essa ideia de fluxo antes da TV britânica.

Ele considera que na primeira metade dos anos de 1970 a TV dos Estados Unidos possuía o conceito de "fluxo verdadeiro". Descreve que "de maneira crescente, tanto na TV pública quanto na comercial, uma outra sequência era acrescentada: trailers de programas a serem exibidos mais tarde ou em outro dia, ou outros noticiosos específicos". (WILLIAMS, 1974, p.91) E conclui que "com a eventual unificação dessas duas ou três sequências, um novo tipo de fenômeno de comunicação tem que ser reconhecido". (Idem, p.91) Acontecerá um fluxo planejado, com produtos pensados e roteirizados para ter intervalos, buscando sempre atrair e prender a atenção do telespectador. O próprio Williams tem dificuldade para descrever algo abstrato como o fluxo e coloca a ideia no patamar de um conceito muito mais ligado ao sensorial do telespectador - devido ao volume de informação ao qual ele está exposto - do que propriamente à uma definição específica. (Idem, 
p.96) O pesquisador britânico ainda conclui que, de todas essas maneiras de exibição e na combinação delas, este é o fluxo de significado e valores de uma cultura específica.

O controle da continuidade televisiva se transforma em um tipo de narrador. Interrupções e mudanças fazem parte das urgências de uma grade de programação que contemple transmissões ao vivo e principalmente se entre os produtos estiver incluído o Jornalismo. Estas mudanças fazem com que a grade crie uma nova semântica que estão sempre interligadas às estratégias traçadas pelo departamento de programação - é quando Herreros considera que a programação alcança o sentido pleno de uma obra aberta.

Por mais controle que exista em uma emissão ao vivo, os produtos estão sujeitos a uma permanente reelaboração e, "adquirem novos sentidos ao serem relacionados com outras mensagens que aparecem antes, depois ou no meio". (HERREROS, 2003, p.389) Há também uma importante ideia de redundância na programação, que alguns teóricos consideram chave para lidar com a distração do público porque a cada vez que uma transmissão se interrompe por qualquer motivo, terá de reconquistar o telespectador.

Na competição entre as emissoras de TV para conquistar o público, a ideia é manter o Espectador em frente do dispositivo, exposto ao fluxo pelo tempo máximo possível. O fluxo torna-se, assim, um elemento fundamental da programação porque e está relacionado à experiência de "assistir TV" e não de assistir produtos individuais na TV.

A programação permite uma organização de conteúdos que constituem uma narrativa per se e dentro dessa narrativa as mensagens se sobrepõem e adquirem dimensões. Herrerros estabelece que na grade de programação há "uma macromensagem que superdimensiona a mensagem particular, ou a micromensagem de cada unidade que a compõe. Para alcançar, a programação estabelece uma coerência textual determinante do discurso global. A coerência é o que permite estabelecer as relações semânticas entre os diversos componentes". (Ibidem, 2003, p.380)

O ápice da linguagem e da programação televisiva se dá na transmissão ao vivo, que seria o momento em que "a obra contém todos os elementos do imprevisível e de se fazer a si mesma segundo após segundo". (Ibidem, p.387). O 
que levar a pensar que a televisão se define e exerce a sua função de dispositivo de comunicação de massa produtor e mediador no momento da emissão quando reúne uma miríade de grupos sociais ao redor do mesmo estímulo distribuído e publicizado pela programação.

Por observação de uma programação de qualquer dia da semana de uma emissora de TV aberta ${ }^{24}$, pode-se perceber que a grade transcende os produtos que apresenta e torna-se, ela própria, um produto da prática audiovisual. Existe enquanto 'ao vivo' e se manifesta num processo comunicacional no tempo presente em sintonia com o conceito do Metáporo e do "presente durante" da pesquisa de Ciro Marcondes Filho.

A partir de uma ideia da nuvem comunicacional, ele fala da volatilidade dos meios de comunicação de massa, em especial da televisão. Oferece a possibilidade de uma percepção sobre o meio e seus produtos com a abstração que necessita e acompanhada da intenção necessária de um devir comunicacional como sendo algo menos denso e duradouro mas não menos quente:

\begin{abstract}
“... é viva, pulsante, continuamente abalada por fatos novos. Ela não tem forma, massa ou densidade: ela atravessa as pessoas e suas mentes e constitui um corte no tempo. O contínuo atmosférico é esse emaranhado de fatos da política, do esporte, das telenovelas, do último crime passional, da nova tendência da moda, do escândalo da celebridade, que duram 15 minutos ou 15 dias, às vezes semanas ou meses, mas são voláteis, etéreos, gasosos". (MARCONDES FILHO, 2012, p.763)
\end{abstract}

As percepções de 'fluxo' de 'ao vivo' exploradas por Yvana Fechine dialogam com Shirky (2011), com Williams (1974) e com Herreros (2003) e levam a uma reflexão sobre o hábito de assistir TV como sendo o 'ver TV'

\footnotetext{
"um tipo de sentido produzido na/pela prática diária de ligar a TV, simplesmente se expondo ao fluxo televisual (ligar a TV para "não ver nada", ou seja, para não assistir a nada em especial): um sentido aquém e além dos próprios programas porque depende, antes de mais nada de um tipo de "contato" do Espectador com seu arranjo

24 Forma de televisão gratuita no Brasil com o maior alcance de público no país. Disponível em: http://adnews.com.br/adcontent/especial-tv-aberta/como-esta-o-cenario-da-televisao-aberta-nobrasil.html 
numa grade de programação que já Ihe é familiar. Trata-se aqui de um sentido que se instaura como um tipo de vivência cotidiana do Espectador com a televisão; um sentido que se identifica com a reiteração do próprio contato do sujeito com sua programação; enfim, um sentido que se instaura no e pelo próprio hábito de assistir à televisão em determinadas condições e circunstâncias".(FECHINE, 2004, p.2)

Fechine reforça a ideia do sentido do hábito de ver TV na medida em que o Espectador '"experimenta' a TV, 'sente' a TV, sem sequer compreendê-la ou se deter nos conteúdos por ela veiculados". Há neste modo de ver TV um certo deslumbramento, "compreendido como uma forma de êxtase das experiências cotidianas, sempre que um outro objeto provoca uma espécie de 'fratura' ressemantizadora do dia a dia do eu-sujeito". (FECHINE, 2004, p.3)

A conclusão de que o hábito é um "modo de fruição no qual a presença familiar do objeto é parte daquilo que nele, e em determinadas condições, faz sentido para um sujeito - um sentido outro. (Idem, pp.3-5) e de que a TV dá sentido ao cotidiano revelando como que "algo ainda desconhecido no conhecido, de um novo sabor do mesmo. (FECHINE in ERTHAL, 2013, p.24)

Dentro desses pressupostos, é reforçada a ideia de que "está no ar" é a programação televisiva que constitui um fluxo de emissão e de recepção dos produtos e uma prática audiovisual com elementos contidos um no outro e determinantes do modo de ver. O fluxo é o que perpassa todas as tecnologias-chave aqui mencionadas. Cada uma, a seu modo, produz um certo tipo de fluxo que irá disciplinar a maneira como o Observador/Espectador/Usuário vai se relacionar com ela enquanto tecnologia e com o conteúdo mediado através destes dispositivos.

\subsection{Controle remoto}

O controle remoto foi um dispositivo criado com a ideia inicial de proporcionar conforto ao telespectador que poderia mudar de canal sem ter que sair do lugar. Tem as suas preferências, influência na audiência e nas grades de programação. As pesquisas de audiência passaram a tentar conhecer melhor o telespectador.

Mais do que o conforto físico, o fato do telespectador ter algum poder de escolha com o controle remoto iniciou uma mudança nos hábitos redisciplinarizando 
a maneira de ver TV. O sujeito em frente ao monitor de TV deixou claro para as emissoras em suas pesquisas de audiência a aceitação ou a recusa por um tipo de produto audiovisual. Quando um Espectador muda de canal porque prefere este ou aquele produto, ou ainda desliga o aparelho, proporciona com sua atitude uma informação que antes talvez só pudesse fornecer numa pesquisa pessoal de audiência ou nas aferições feitas com aparelhos instalados nas residências que indicam o canal onde o telespectador está sintonizado.

Mas apenas com o controle remoto ainda não era possível especificar quais tipos de programas ele gostaria de ver, e detalhes ainda mais profundos da relação entre a programação e o público. Por isso, pesquisas de audiência foram e continuam sendo uma fonte importante e, às vezes determinante, na programação e na produção audiovisual das redes de TV e agora da Internet.

O controle remoto e os canais de televisão com programação ininterrupta vinte e quatro horas por dia e sete dias por semana aos poucos tiraram o sujeito comunicacional/Espectador do século 20 do lugar de passividade em frente da televisão. Levaram-no para um lugar novo de atividade em relação ao monitor, primeiro da TV, depois do computador e posteriormente no uso dos dispositivos móveis de acesso à informação, aos produtos audiovisuais e na produção/atuação sobre a informação que circula na Internet como veremos em capítulos posteriores da pesquisa.

O uso do controle remoto e as transformações que trouxe para o Espectador e para a indústria audiovisual são incontáveis e amplamente estudados ao longo do tempo. É um dispositivo que permite inúmeras leituras sobre os novos tipos de comportamento diante dos meios de comunicação de massa. A aceleração, a fragmentação da imagem, uma "desreferencialização da imagem" ${ }^{25}$ em colaboração

\footnotetext{
${ }^{25}$ No texto $O$ controle remoto e a interatividade na televisão, Eduardo Natário e Solange Wajnman dizem:

"Em um zapping uma 'cena nova' não possui relação com a anterior e a construção que cada um faz é única. Isso faz com que não seja raro um Espectador apenas 'contemplar a imagem' sem se importar com o que tais cenas signifiquem. Por vezes não se encontram mais nessas cenas, ou nessa frenética alternância de imagens, referencias ou equivalentes no mundo real. A ação do Controle Remoto na tevê, nesse cenário pós-moderno e de imagens desreferencializadas, faz desse objeto um representante ilustre (Totem) dessa visão de do mundo contemporâneo, pois é ele que permite a catalisação de tal situação imagética. A digitalização dos vídeos domésticos e o compartilhamento destes com outras pessoas, como uma comunidade virtual em rede, contribui para reafirmar mais um conceito pós-moderno, o da destotalização. Mesmo com as tendências descritas acima, é difícil criar modelos imperativos e universais em uma sociedade com esse panorama, pois a própria falta de referência não permite criar leis estanques, mas sim identificar tendências, mostrar caminhos e reconhecer as características dos meios de comunicação". (2006, p.15)
} 
com a situação pós-moderna dos meios de comunicação no final do século 20 e início do 21 quando já se atinge uma nova possível categoria produzida com a velocidade da Internet.

Após a entrada de um dispositivo já tão importante, outros estariam por vir e transformariam já alguns aspectos da maneira de ver TV. Com a chegada do VHS, o Espectador ganhou um pouco mais de independência e já podia escolher quando ver ou rever a programação gravada. Uma revolução no modo de assistir TV porque a partir de então ele passava a montar a sua grade de programação e excluir inclusive os intervalos comerciais da sua lista, o que levou emissoras, anunciantes e departamentos de marketing e vendas a rever conceitos e desenvolver novos modelos de comercialização. Afinal, o anúncio ainda é a principal fonte de renda para a produção televisiva. E se tornou uma grande fatia na monetização para as empresas de Internet.

O VHS evoluiu para outros dispositivos como DVDs, e mais adiante os HDs e pen drives e, atualmente, os sistemas de fornecimento de conteúdo em streaming ${ }^{26}$ mudando, então definitivamente, a forma de ver TV.

Com a mudança da agenda televisiva o aparelho de TV se transformou numa central de entretenimento que recebe diferentes sinais e sistemas provedores/players de conteúdo ao assinante dos serviços e trouxe a possibilidade de acesso dos produtos audiovisuais quando e onde o Espectador quiser nos mais diversos dispositivos e telas como celulares e tablets. É quando acontece a transição de Espectador para Usuário quando passa de uma pessoa que assiste os serviços disponibilizados pela tecnologia para se transformar numa pessoa que tem contato com o material oferecido no momento da sua escolha, reconfigurando grades de programação, agora de uma maneira mais autônoma.

As novas formas de programação se estabelecem quando os produtos são, gravados, salvos, postados e determinam um novo fluxo de informação que não

\footnotetext{
${ }^{26}$ Over the top (OTT) é uma forma de distribuição de conteúdo que permite ao provedor a comercializar áudio e vídeo e outros serviços de mídia diretamente ao consumidor através da internet por streaming como um produto único e individual sem te que passar pelos provedores dos sistemas de telecomunicações, cabo ou TV aberta que estão configurados tradicionalmente como os controladores ou distribuidores deste tipo de conteúdo. O OTT se refere em particular ao conteúdo que chega por uma terceira parte como Hulu, Netflix, Sling TV, WhereverTV, TikiLIVE, Amazon Video, AppleTV ou Xumo. E é entregue por um dispositivo externo de Usuário final (end-user) deixando o serviço de transportar os pacotes de IP para o ISP.

Disponível em: http://www.e-compos.org.br/e-compos/article/view/60/60

Último acesso em 23 de março de 2018.
} 
passa diretamente pelos grandes conglomerados de mídia. Passa pelas novas corporações que vivem na era da internet. São elas que impõem hoje o conteúdo que circula entre os Usuários. Empresas como Google, Facebook, e aplicativos como Whats App, Instagram, Snapchat, Youtube ${ }^{27}$ possuem algumas das informações mais valiosas no mundo atual: o perfil dos Usuários. Assim, os produtores de conteúdo têm uma noção, até hoje inédita e em escala global, de quem é o público que o assiste.

O capitalismo desconhece fronteiras geográficas e se estabelece fronteiras relativas ao capital. No caso de uma emissora de TV ou produtora de filmes por exemplo, o Usuário talvez não possa interferir diretamente sobre o conteúdo ou o fazer do produto em si, mas algoritmos se multiplicam e processam o acesso das mais diversas formas, determinam preferências e a partir das conclusões mercadológicas as corporações estabelecem a necessidade de criação, desenvolvimento e publicação de determinados produtos. É uma forma de influenciar na produção de conteúdo.

No caso de um canal no Youtube, ou de um blog, quem posta normalmente é o autor e praticamente sem interferências externas do próprio conteúdo embora as empresas proprietárias de cada uma destas redes estabeleçam determinações de uso de linguagem, imagens e áudios. Utilizam filtros internos desenvolvidos pelo próprio sistema para impedir a publicação de alguns materiais considerados "impróprios". Todos as pessoas que participam das redes sociais devem, portanto, conhecer os termos e saber que estão sujeitas a estes filtros.

As redes sociais são algumas das ferramentas mais importantes na produção de conteúdo atual. A partir de um post, do número de seguidores de quem postou, do número de acessos e repercussão de um post ou uma $L_{i v e}{ }^{28}$ esta pessoa possui mais ou menos visibilidade o que implica em eventualmente ser remunerado pelo número de acessos ou ser invisível na rede.

Um aspecto peculiar do comportamento do novo Espectador/Usuário passou a se manifestar com o controle remoto: a opção movida pelo desejo. Hoje talvez o principal controle remoto seja o inseparável telefone celular inteligente (smartphone).

\footnotetext{
${ }^{27}$ Facebook é atualmente dono do Whats App e Instagram.

${ }^{28}$ A Live é um recurso disponível em algumas redes sociais, como o Facebook, que permite a transmissão de vídeos em tempo real. E o Facebook Live é uma ferramenta do Facebook para a emissão de material ao vivo por parte dos usuários da rede social.
} 
Como todas as funções, utilidades, aplicativos, fornece a sensação de controle absoluto da vida intimamente ligada à tecnologia. E um dos aspectos que mais interessa a essa pesquisa é o fato do consumidor/Usuário ter opção. Este ingrediente novo na vida dele torna-o menos passivo e mais opinativo. Da mesma forma que Kant ${ }^{29}$ define que a visão e a percepção são subjetivas, que cada Observador é diferente um do outro, ao invés de uma massa única de Espectadores passa a ser considerado um indivíduo que pode optar, numa outra época já ciente de que outros elementos têm influência, a essa opinião foram atribuídos valores que influenciam em modelos de negócio. A comercialização das emissoras de TV é baseada em pesquisas de opinião indicativas de preferências e recusas de grupos, classes sociais, tipos culturais e econômicos dos Espectadores. A TV ainda continua a considerar o espectador em grupo e não individualmente como na Internet, onde é possível traçar um perfil ainda mais particular do Espectador/Usuário.

\subsection{Usuário do século 21 - a renovação do olhar}

As telas móveis se inserem na vida onde a tecnologia é protagonista do cotidiano. O Usuário pertence ao século 21 e não depende apenas da televisão para assistir aos produtos audiovisuais ou ter acesso à informação que antes chegariam até ele pelos meios convencionais. Passa a ter na TV mais um dispositivo de entretenimento e nem sempre o principal. Computadores, tablets, e telefones celulares ocupam este espaço e a fonte de emissão dos produtos audiovisuais não é mais necessariamente uma emissora ou rede de televisão responsável pela produção do material, mas um canal de Internet.

O serviço de internet doméstica se tornou rapidamente - em menos de vinte anos - uma das fontes de escala global mais importantes de acesso a informação com a diversidade de canais, sites, mecanismos de busca, o que colocou os meios de comunicação de massa tradicionais como rádio, jornais/revistas e televisão num segundo plano em relação à Internet. Esta passou a ser a nova norma.

Em tese, o Usuário não pertence necessariamente a uma faixa etária definida ou a uma classe social e econômica específicas. Embora não se ignore alguns

${ }^{29}$ Immanuel Kant. Crítica da Razão Pura, Fundação Kalouste Gulbenkian, 1994, p.22 
detalhes. Basta ter o acesso, condições econômicas para tanto e o desejo de assistir a produtos pela rede. Dito isso, é importante explicar que embora a idade seja indefinida, há um amplo acesso à tecnologia nas faixas etárias mais jovens, e muitas vezes, um aprendizado mais intenso e rápido para lidar com novas tecnologias, equipamentos, ferramentas, aplicativos, etc., devido a um contato desde a primeira infância com este universo. Mas não há nesta pesquisa restrição para tal. No que se refere à classe social, sabe-se que o Usuário terá mais ou menos acesso à Internet dependendo do tipo de plano de dados contratado e das condições econômicas que podem ser definidoras de um tipo de acesso, privilegiando uma classe social em detrimento de outra. Um acesso aos players televisivos, restrito por questões econômicas que o impedem de assinar o serviço e/ou porque o consumo de dados é maior quando um produto audiovisual é assistido a ponto de inviabilizar o uso de outros aplicativos e/ou funções do dispositivo. 
Capítulo 3

SUJEITO/USUÁRIO: A BUSCA DA IDENTIDADE NA MODERNIDADE TARDIA 


\title{
3. Sujeito/Usuário: a busca da identidade na modernidade tardia
}

\author{
'A importância da localidade persiste mesmo em face \\ das maciças mudanças tecnológicas e sociais'. \\ Meyrowitz, $2005^{30}$
}

O Usuário é ator e produtor de mudanças que transformam a sociedade nas primeiras décadas do século XXI. Habita um universo "fragmentado de paisagens culturais de classe, gênero, sexualidade, etnia, raça e nacionalidade que no passado nos tinham fornecido sólidas localizações como indivíduos sociais". (HALL, 1992, p. 9) Transita por um volume infinito de informações e cruzamentos de dados e por ambientes transnacionais, no sentido de que estão localizados num determinado lugar e possuem a carga de uma cultura ou mescla cultural com todos os ingredientes sociais, políticos e econômicos que o formam. Porém, este é um sujeito com um senso de deslocamento de lugar, ao pertencer a um universo global da rede e que não necessariamente quer ser percebido como um ponto específico deste ou daquele local, mas habitante da rede como um todo, que é o local universal desta reflexão.

Para que o acontecimento comunicacional em rede ocorra, o Usuário necessita de visibilidade constante. Navega pela Internet deixando rastros de um percurso geopolítico através de suas preferências e postagens e que, dependendo da frequência com que acontecem, tornam este sujeito mais ou menos visível. Aparentemente ele alcança a visibilidade através da resposta do outro que, como ele, habita uma comunidade virtual situada em locais abstratos da rede.

São comunidades, redes sociais, blogs, sites, atos de comunicação que se revelam com noções simultâneos de local e de global. Agregam linguagem, sistemas simbólicos, economias e culturas com trânsito universal e acessível, a depender também de dois fatores que podem, por ventura, inibir alguns Usuários de participarem desta conexão: a língua escolhida para se comunicar. Ultrapassada esta barreira, a comunicação acontece. $E$ se a linguagem escolhida for 0 audiovisual, a barreira da língua pode ser ultrapassada ainda mais rapidamente pelo

\footnotetext{
30 "The significance of locality persists even in the face of massive social and technological changes". Meyrowitz, 2005, p.21. (Tradução da autora).
} 
fato de que imagens e sons se mostram uma fala compreendida de maneira ainda mais universal do que o texto escrito.

O segundo fator se localiza num contexto sócio econômico brasileiro, que pode influenciar no acesso à informação e também na visibilidade desejada e o fator econômico não pode ser ignorado. Em termos de qualidade de banda larga, o fornecimento de internet no país é considerado inferior a outros países e também oneroso financeiramente dentro do orçamento doméstico, o que sem dúvida, influencia na visibilidade do Usuário. ${ }^{31}$ Esta pesquisa percebe a existência deste cenário e considera como Usuário o sujeito que se mantém conectado na internet o maior número de horas diárias possível, que se expõe cultural e socialmente na rede e assim permanece e pretende permanecer. Por uma questão geracional ou de conhecimento da própria realidade, o Usuário talvez não tenha uma percepção crítica da sua exposição e está conectado simplesmente porque esta é a realidade de seu tempo e a sua própria. Um assunto que trataremos mais adiante num dos textos de Crary (2014).

O propósito aqui é falar de uma certa crise de identidade, e também dos questionamentos que levam à busca de uma identidade. Coloca-se assim uma forma de investigar uma possível crise do sujeito Usuário aqui analisado no contexto que frequenta basicamente porque se torna 'é' o contexto, quando ator/produtor de informação. Exposto 24 horas por dia na rede, ambientes virtuais, de realidade aumentada ou ainda ambientes reais, ele existe num universo pós-moderno, na medida em que é um sujeito comunicacional na modernidade tardia.

O conceito de modernidade tardia pode ser compreendido dentro do próprio Hall (1992), bem como numa análise do pensamento de Habermas e Giddens, passando por Beck estabelecido por Luvizotto (2013). No texto de Hall, Habermas entende as sociedades modernas num estado de alta ou radicalizada modernidade com um grau elevado de reflexividade. E Giddens (1997), "prefere a expressão

\footnotetext{
31 Disponível em:

https://tecnologia.uol.com.br/noticias/redacao/2017/03/01/brasil-e-um-dos-paises-maisdesconectados-do-mundo-sao-70-milhoes-offline.htm
}

http://www.correiobraziliense.com.br/app/noticia/tecnologia/2015/01/16/interna tecnologia,466727/bra sil-esta-em-90-no-ranking-mundial-de-velocidade-da-internet.shtml

http://veja.abril.com.br/blog/impavido-colosso/brasil-e-o-9-pais-com-a-pior-velocidade-de-internetbanda-larga/

Último acesso para os três links em 20 de março de 2018. 
modernidade reflexiva ou tardia, pois acredita que a modernização reflexiva possibilita o entendimento e a criação de interpretações que possam responder às descontinuidades da modernidade, geradas a partir das mudanças da vida moderna". (LUVIZOTTO, 2013, pp. 250-251.)

O próprio Giddens reflete sobre os riscos da sociedade global criada neste contexto da modernidade tardia e tem uma primeira visão pessimista dos riscos que esta pode oferecer quando diz que o desenvolvimento industrial traz uma série de males e que esta

\footnotetext{
"é uma sociedade em que os mecanismos da verdade se modificam - de maneiras interessantes e importantes. O que pode ser chamado de confiança ativa torna-se cada vez mais significativo para o grau em que emergem as relações sociais pós-tradicionais. A confiança ativa é a confiança que tem de ser tratada e mantida com energia. Hoje em dia, está na origem das novas formas de solidariedade social, em contextos que variam desde os laços pessoais íntimos até os sistemas globais de interação". (GIDDENS, 1995, pp.221-222)
}

E fala de perto ao universo do Usuário ainda num momento precoce do desenvolvimento das redes sociais e da participação em rede quando o Usuário começava a dar os primeiros passos.

A identidade do sujeito comunicacional Usuário é construída através da permanência dele na rede como ator e produtor de informação, porque é pela visibilidade - quando está conectado - que se dá a sua existência. Um Usuário em silêncio, ausente de participação, é um Usuário invisível e deixa de existir enquanto ator de um momento presente e ao vivo da comunicação. Portanto, não seria equivocado afirmar que ele se constrói de maneira permanente enquanto está atuante e tem o seu "apagamento cultural" (BHABHA, 1998) e social quando está off-line. É uma identidade transitória, questionada pela existência de uma ação e colocada em xeque no momento da desconexão.

No entanto, para que esta reflexão seja possível, é necessário que fiquem claras algumas noções sobre a construção da identidade, ainda que o sujeito esteja num trânsito permanente de afirmações identitárias como parece acontecer com o Usuário.

Juntamente com Hall, é importante compreender o conceito de Castells para quem a identidade é um "processo de construção de significado com base em um atributo cultural, ou ainda um conjunto de atributos culturais inter-relacionados, o(s) 
qual(is) prevalece(m) sobre outras fontes de significado" (CASTELLS, 1999, p. 22). Esta percepção leva a definições de "Papeis" como normas estruturadas pelas instituições e organizações da sociedade. Para ele, "Identidades" constituem "fontes de significação para os próprios atores, por eles originadas, e construídas por meio de um processo de individuação". (Idem)

Considerando a hipótese de que a identidade é questionada quando há uma crise, há que se refletir sobre o pensamento de Mercer quando coloca questões sobre a atualidade dos mapas políticos. Embora ele fale de uma crise de identidade política ligada a um contexto europeu das duas últimas décadas do século $X X$ e as movimentações políticas daquele momento, as ideias mais adequadas estão também intimamente ligadas ao fruto da época que é o Usuário contemporâneo. $E$ mesmo que este trabalho não pretenda dirigir toda a atenção a esta questão, a história cotidiana mostra que os contextos e movimentações referidos pelo texto de Mercer não estão separados do assunto tratado. Ao contrário, parecem por vezes mais próximos e como se deixassem permear um pelo outro numa movimentação global de tendências ideológicas. Ele diz que a crise da identidade acontece

\footnotetext{
"A partir desse ângulo, o esforço para falar de identidade é sintomático da situação pós-moderna da política contemporânea. (...) Nossos mapas convencionais não estão mais adequados ao território, na medida em que a paisagem política tem sido radicalmente reestruturada pela hegemonia da Nova Direita. Daí que não existem termos incertos, a crise de identidade 'da Esquerda". (MERCER, 1990, p. 43) ${ }^{32}$
}

\subsection{Local da Cultura}

O sujeito comunicacional que vislumbramos na figura do Usuário busca uma forma de pertencimento diante de uma Nação abstrata por ele habitada. Mesmo como um sujeito transnacional, há uma busca de uma tradição local, ao mesmo tempo em que de uma projeção global. É um sujeito que parece viver uma

\footnotetext{
${ }^{32}$ From this angle, the eagerness to talk about identity is symptomatic of the postmodern predicament of contemporary politics. The salient ambiguity of the word itself draws attention to the break-up of the traditional vocabulary of Left, Right and Centre. Our conventional maps are no longer adequate to the territory as the political landscape has been radically restructured over the last decade by the hegemony of the New Right. Hence, in no uncertain terms, the 'identity crisis' of the Left."(MERCER, 1990, p.43)
} 
permanente crise de transitoriedade na qual o pertencimento do todo global e universal é um devir acompanhado das características culturais específicas que demonstram a singularidade e subjetividades.

O Usuário é um sujeito que acontece no tempo presente e se manifesta durante $\mathrm{O}$ ato comunicacional, aliás, $\mathrm{O}$ ato comunicacional é ele próprio, numa imbricação ator/Espectador/sujeito no seu momento de produção e presença na rede. O local desse sujeito é tensionado pelo movimento e pela transitoriedade e guarda aspectos de uma faceta cultural transnacional. É onde há um diálogo com o local cultural de Bhabha. Ele ressalta que é preciso traduzir o local especificamente a cada vez "de forma a não ser subjugado pelas novas tecnologias globais de transmissão ideológica e consumo cultural". (BHABHA, 1998, p. 333)

Bhabha e Hall tratam do assunto do local da cultura e da identidade do sujeito cultural respectivamente a partir de conceitos de colonialismo e cultura na modernidade tardia sob a ótica dos Estudos Culturais e com ênfase nos assuntos de colonização e transformações culturais na contemporaneidade. Mesmo que o tema desta pesquisa não seja diretamente o tratado pelos autores, a fala deles caminha junto na busca por uma percepção sobre qual é o local cultural do sujeito/Usuário nesta suposta nação a qual ele pertence ou tenta pertencer.

Timothy Brennan lembra que a palavra nação refere-se "tanto ao moderno estado-nação quanto a algo mais antigo e nebuloso - a natio - uma comunidade local, um domicílio, uma condição de pertencimento" (Brennan, 1990 in HALL, 1992, p. 58). O Usuário parece também ter a uma nação imaginária, com uma cultura própria, e se manifesta num híbrido identitário permanente, numa transitoriedade na qual busca se afirmar, ser visível e se manifestar tendo que se transformar para ser visível para o outro. A ideia de Nação para Hall está ligada ao pertencimento.

É perceptível as redes sociais como nações modernas porque são todas híbridos culturais: não são unificadas em torno de uma raça, um povo, cultura ou etnia. Trabalham com a diversidade, a aceitação ou a recusa, com parâmetros de convivência e possuem categorias discursivas. O mesmo se poderia falar da Internet? Seria a rede mundial uma grande nação? Ter uma cultura nacional é também ter uma estrutura de poder cultural. O Usuário parece ser essa 'mini-nação' de um homem só, inserido em comunidades que por vezes assumem números de 
alguns dos maiores países do mundo. ${ }^{33}$ Se pensarmos em redes sociais, veremos números de nação. E poderes também. A pergunta de Stuart Hall é a mesma que se faz agora: "Seria a identidade nacional (...) uma identidade que anula e subordina a diferença cultural?" (HALL, 1992, p.59) E há que se completar: quando é esta mesma diferença que a alimenta?

Ele traz a ideia de indivíduo nas sociedades da modernidade tardia e caracterizadas pela diferença. Para o autor, as sociedades "são atravessadas por diferentes divisões e antagonismos sociais que produzem uma variedade de diferentes 'posições de sujeito' - isto é, identidades - para os indivíduos”. (Idem, p. 17)

A partir deste aporte teórico, é possível compreender que o Usuário está em permanente elaboração de um sujeito identitário. Assim como o nascimento de um indivíduo soberano entre o Humanismo Renascentista do século XVI e o lluminismo do século XVIII significou uma ruptura importante com o passado, talvez tenha sido ele que colocou todo o sistema social da modernidade em movimento, como nos lembra Hall (Ibidem, p.25). Por isso existe uma visão do descentramento e conceptualização do sujeito moderno que é necessária de ser visualizada.

A ideia de que a internet transcende as barreiras nacionais e promove $\mathrm{O}$ status do capital à um bem global se ampara nos argumentos de Hall quando

33 Tradução da autora: Até o momento, mas inúmeras outras devem surgir até o encerramento deste texto. Twitter tem pelos menos 700 milhões de Usuários ativos diariamente. Facebook conta com dois bilhões de Usuários. Periscope fornece aos seguidores streaming ao vivo em vídeo com alta qualidade. $\mathrm{O}$ aplicativo permite a qualquer Usuário do Twitter a opção de exibir material ao vivo com um alcance global [atual] de 500 milhões de Usuários com a opção de usar a hashtag para promover o seu conteúdo. O Snapchat - lançado em 2011 e tem perto de 200 milhões de Usuários que postam cerca de dois bilhões de histórias por dia visualizadas em todo o planeta. O Instagram conta com pelos menos 800 milhões de Usuários que se multiplicam por bilhões de fotos.

Para Facebook acesso em:

http://idgnow.com.br/internet/2017/06/27/facebook-atinge-a-marca-de-2-bilhoes-de-usuarios-nomundol

Para Twitter:

http://idgnow.com.br/internet/2017/05/03/twitter-ganha-apenas-9-milhoes-de-usuarios-no-10-trimestre/ Para Snapchat:

https://g1.globo.com/tecnologia/noticia/dona-do-snapchat-registra-numero-de-usuarios-abaixo-doesperado-e-acoes-caem.ghtml

Para Periscope:

http://www.scribblelive.com/blog/2015/06/10/new-content-marketing-strategy-utilize-snapchatmeerkat-twitter-periscope/

Para Instagram:

https://g1.globo.com/tecnologia/noticia/instagram-tem-800-milhoes-de-usuarios-ativos-por-mes-e-500milhoes-por-dia.ghtml

Último acesso em 21/3/2018. 
conversa com Giddens (1990, p.63), Held (1992) e Wallerstein (1979). Os dois primeiros defendem que "a modernidade é inerentemente globalizante e que os estados-nação nunca foram tão autônomos ou soberanos quanto pretendiam. E o terceiro deixa claro que o capitalismo sempre se colocou como um "um elemento da economia mundial e não dos estados-nação. O capital nunca permitiu que suas aspirações fossem determinadas por fronteiras nacionais" (Wallerstein, 1979, p. 19). Por isso, ainda segundo Wallerstein, tanto a tendência à autonomia nacional quanto a tendência à globalização estão profundamente enraizadas na modernidade". (1991, p. 98 in HALL, 1992, p. 68)

O movimento na rede que faz com que o sujeito se reposicione constantemente produzindo novos elementos. O Usuário está em permanente reposicionamento identitário no caminho da visibilidade porque é assim que ele estabelece a afirmação da identidade. A estrutura de identidade que permanece aberta proporciona a noção de movimento necessária, adere bem à realidade atual de um sujeito/Usuário, senhor da ação no momento presente. $O$ sujeito indivisível e também dono de uma identidade singular, distintiva, única como fala Williams quando observa que a história moderna do sujeito individual reúne dois significados distintos. (WILLIAMS 1976, pp. 133-5 in HALL, 1992, p. 25).

A orientação geopolítica do Usuário não é sempre um movimento físico, que nesse campo da Internet se apresenta também como um físico/virtual e um geográfico/virtual. A necessidade de estar nos lugares é suprimida fisicamente pela movimentação online e o Estar é compreendido naturalmente como o Ser Visto. A mobilidade do Usuário faz dele um sujeito móvel, um Flâneur virtual e faz com que a comunicação dele também seja móvel, permanente, constante, ao vivo e durante. Ele rearticula a identidade em torno de um deslocamento contido no conceito de globalização para a "produção de novos sujeitos" (HALL, 1992, p.18) e para o que Hall chama de "recomposição da estrutura em torno de pontos modais particulares de articulação". (LACLAU in HALL, 1992, p.40)

\subsection{Sujeito e poder}

Diante de um sujeito descentralizado/deslocado na modernidade tardia a partir de um ponto de vista do que a sociedade e a cultura consideram o centro, Hall 
trabalha com cinco pontos de descentramento do sujeito. Todos igualmente importantes para linha de pensamento que ele desenvolve, e neste caso, destaca-se um deles que dialoga mais de perto com esta pesquisa que é o sujeito moderno descentrado a partir do que Michel Foucault chama de "poder disciplinar" que se desenvolve no século 19 quando da formação também do Observador, e atinge um ápice no século 20 em que o Espectador se formará. Mesmo que Foucault não tenha conhecido os Usuários, o poder sobre um Sujeito se estende durante o século 21.

O poder disciplinar ao qual Foucault se refere

\begin{abstract}
"está preocupado, em primeiro lugar, com a regulação, a vigilância é o governo da espécie humana ou de populações inteiras e, em segundo lugar, do indivíduo e do corpo. Seus locais são aquelas novas instituições que se desenvolveram ao longo do século XIX e que "policiam" e disciplinam as populações modernas - oficinas, quartéis, escolas, prisões, hospitais, clínicas e assim por diante". (HALL, 1992. P. 42)
\end{abstract}

A manutenção das atividades socioeconômicas, incluindo também as subjetividades como desejos e prazeres, além da saúde física e moral, as práticas sexuais e a vida familiar estão no escopo do poder disciplinar estudado por Foucault. E Dreyfus e Rabinow completam que o objetivo básico deste poder é produzir "um ser humano que possa ser tratado como um corpo dócil" (Dreyfus e Rabinow, 1982, p. 135).

Hall também explora este ponto de vista a partir da história do sujeito moderno quando a individualização do sujeito aumenta provocada pela aplicação do poder e do saber e "envolve mais intensamente seu corpo". Diz que "quanto mais coletiva e organizada a natureza das instituições da modernidade tardia, maior o isolamento, a vigilância e a individualização do sujeito individual". Foucault complementa a ideia da individualização, do isolamento e da docilidade:

\footnotetext{
O poder não apenas traz a individualidade para o campo da observação, mas também fixa aquela individualidade objetiva no campo da escrita. Um imenso e meticuloso aparato documentário torna-se um componente essencial do crescimento do poder [nas sociedades modernas]. Essa acumulação de documentação individual num ordenamento sistemático torna "possível a medição de fenômenos globais, a descrição de grupos, a caracterização de fatos coletivos, o cálculo de distâncias entre os indivíduos, sua distribuição numa dada população" (FOUCUALT in DREYFUS et RABINOW, 1982, p. 159).
} 
Foucault trata do assunto também no texto O Sujeito e o Poder, que merece um olhar mais aprofundado nesta pesquisa. Além de perceber modos pelos quais o sujeito se estabelece, ele destaca que dentro de uma forma de poder que faz dos indivíduos sujeitos, há dois significados para a palavra sujeito: "sujeito a alguém pelo controle e dependência, e preso à própria identidade por uma consciência ou autoconhecimento". (FOUCAULT, 1995, p. 235). Segundo ele, seriam três os tipos de luta das quais o sujeito irá ou precisará lançar mão em algum momento:

\begin{abstract}
"contra as formas de dominação (étnica, social e religiosa); contra as formas de exploração que separam os indivíduos daquilo que eles produzem; ou contra aquilo que liga o indivíduo a si mesmo e o submete, deste modo, aos outros (lutas contra a sujeição. Contra as formas de subjetivação e submissão)". (Idem)
\end{abstract}

A nova forma de organização de poder que se delineia no século XVIII traz uma matriz moderna da individualização, como fala Foucault, ou o que chama de "uma nova forma do poder pastoral". E descreve este tipo de poder em três etapas: a salvação e suas formas; a administração do poder pastoral e a multiplicação o dos objetivos e dos agentes do poder. ${ }^{34}$

\footnotetext{
34 1. "Podemos observar uma mudança em seu objetivo. Já não se trata mais de uma questão de dirigir o povo para a sua salvação no outro mundo. Mas antes, assegurá-la neste mundo. E. neste contexto, a palavra salvação tem diversos significados: saúde, bem-estar (isto é, riqueza suficiente, padrão de vida). Segurança, proteção contra acidentes. Uma série de objetivos "mundanos" surgiu dos objetivos religiosos da pastoral tradicional, e com mais facilidade. Porque esta última, por várias razões, atribuiu-se alguns destes objetivos como acessório; temos apenas que pensar no papel da medicina e sua função de bem-estar assegurados, por muito tempo, pelas Igrejas católica e protestante.
}

2. Concomitantemente, houve um reforço da administração do poder pastoral. Às vezes, esta forma de poder era exercida pelo aparelho do Estado ou, pelo menos, por uma instituição pública como a polícia. (Não nos esqueçamos de que a força policial não foi inventada, no século XVDI, apenas para manter a lei e a ordem, nem para assistir os governos em sua luta contra seus inimigos, mas para assegurar a manutenção, a higiene, a saúde e os padrões urbanos, considerados necessários para o artesanato e o comércio) Outras vezes, o poder se exercia através de empreendimentos privados, sociedades para o bem-estar, de benfeitores e, de um modo geral, de filantropos: Porém, as instituições antigas como a família eram igualmente mobilizadas, nesta época para assumir funções pastorais. Também era exercido por estruturas complexas como a medicina, que incluíam as iniciativas privadas, com venda de serviços com base na economia de mercado. Mas que incluíam instituições públicas como os hospitais.

3. Finalmente, a multiplicação dos objetivos e agentes do poder pastoral enfocava o desenvolvimento do saber sobre o homem em torno de dois polos: um, globalizador e quantitativo, concernente à população; o outro, analítico, concernente ao indivíduo. 
O Usuário parece fazer uso de um poder praticamente "pastoral" dentro da rede e de comum acordo com a manutenção de uma estabilidade necessária para realização pessoal. A internet se projeta com um poder de Estado sobre a vida contemporânea transformando individualidades em fenômenos de massa sob a égide da visibilidade e do pertencimento. É um acordo comum o fato de acessar a rede e atuar nela e com causas e consequências, exaustivamente estudadas por autores que dedicaram seus trabalhos exclusivamente ao assunto. Alguns deles serão vistos mais adiante nesta pesquisa. Mas por enquanto, este texto pretende entender a relação do sujeito e do poder e quais os acordos que estão em jogo para que ele continue conectado e ativo na rede.

A visibilidade e a inclusão estão sempre em jogo quando o Usuário atua na rede. As mídias utilizadas para obter esta visibilidade que, por sua vez significa também inclusão, não necessariamente exercem poder sobre os Usuários mas neles e com eles, principalmente se pensarmos que comunicar é, de uma certa forma, agir sobre os outros, como diz Foucault. O que está em jogo neste ponto é uma circulação de informações e de elementos significantes dentro da economia comunicacional e também a relação entre indivíduos e o seu senso de Nação, de local cultural. É esclarecedor quando ele diz que a palavra 'poder' determina uma relação "entre 'parceiros"” e que, de maneira geral, é constituída por "um conjunto de ações que se induzem e se respondem umas às outras". (FOUCAULT, 1995, p.240) porque afasta uma ideia conspiratória de poder como uma via de mão única onde cabe apenas a opressão e traz à luz a ideia que o poder funciona como um jogo em que há uma disposição das partes para que se estabeleça. Não está pressuposto com isso que o poder não seja opressivo e opressor e que não haja desigualdade nas relações. Mas é necessário compreender que mesmo que o sujeito não tenha uma noção crítica a esse respeito, desconheça outros tipos de realidades e que tenha sido condicionado para o exercício de tal relação, o que interessa a este trabalho é compreender que o poder nos meios de comunicação não acontece de maneira isolada, mas a partir de um conjunção entre poder/interesse/necessidade

E isto implica que o poder do tipo pastoral, que durante séculos - por mais de um milênio - foi associado a uma instituição religiosa definida, ampliou-se subitamente por todo o corpo social; encontrou apoio numa multiplicidade de instituições. E, em vez de um poder pastoral e de um poder político, mais ou menos ligados um ao outro. Mais ou menos rivais, havia uma "tática" individualizante que caracterizava uma série de poderes: da família, da medicina, da psiquiatria; da educação e dos empregadores." (O Sujeito e o Poder - FOUCAULT, p.238) 
que atua sobre as subjetividades do Usuário criando para ele um ambiente favorável para a "assinatura" de um acordo afetivo de trocas, inclusão e visibilidade.

As relações de comunicação implicam em atividades finalizadas e comprovam os efeitos de poder quando modificam o que Foucault chama de "campo de informação dos parceiros". O ato comunicacional do poder se dá na produção e troca de signos num ambiente de fluxo de informação dentro deste acordo orgânico que não está dissociado "das atividades finalizadas, seja daquelas que permitem exercer este poder (como as técnicas de adestramento, os procedimentos de dominação, as maneiras de obter obediência), seja daquelas que recorrem para se desdobrarem, a relações de poder (assim na divisão do trabalho e na hierarquia das tarefas". (FOUCAULT, 1995, p.241)

Levando-se em conta que "o poder só existe em ato", o poder precisa do outro para que as reações e respostas se tornem plenas e para ser exercido. $O$ poder age sobre as ações e sobre a atividade. Necessita de pessoas livres e disponíveis. Portanto, "ele não é, em si mesmo, renúncia, uma liberdade, transferência de direito, poder de todos e de cada um delegado a alguns" (FOUCAULT, 1995, p.241). É uma ação sobre ações presentes ou futuras, como coloca o pesquisador francês.

Dentro da perspectiva do Usuário uma reflexão que se coloca é a de que se o poder opera diferenciações para ser exercido, não seriam as próprias diferenças identitárias formas de combater o poder? $O$ fato de que o Usuário entende o seu local cultural não torna a identidade uma forma de liberdade e de resistência ao poder?

Quando Foucault argumenta que a sociedade moderna fixa uma individualidade para o sujeito ele não demonstra que esta seja uma individualidade positiva, mas que se trata de uma determinação necessária para o funcionamento de um establishment e que busca um volume de informação infinito para o pleno exercício do poder. A individualidade estabelecida é se mostra também como um modelo de controle no qual o sujeito é despido de contornos subjetivos para se tornar o coletivo e aceito na massa. O sujeito aceito coletivamente já não parece guardar individualidades.

O Usuário torna-se então um indivíduo/coletivo, visível e aceito no ambiente frequentado de grupo/comunidade. Quanto mais indivíduo, mais dentro de uma ideia 
de coletivo ele está. E é o coletivo que dita a individualização do sujeito 'permitindo' que ele se veja como individualizado a partir de conceitos de normatização, como em Canguilhem quando se refere às origens da normatização e da noção de normalidade criadas nas sociedades ocidentais. Para ele "o normal é, ao mesmo tempo, a extensão e a exibição da norma". (CANGUILHEM, 2009, p.108). A norma que unifica o diverso e institui um estado de coisas satisfatório: "uma norma se propõe como um modo possível de unificar um diverso, de reabsorver uma diferença, de resolver uma desavença". (Idem, p. 109).

Dentro de um universo de circulação intensa de informações é necessário estabelecer contratos afetivos de atuação e Williams fornece algumas bases para compreender a emergência da noções e relações de individualidade na modernidade:

\begin{abstract}
"...pode ser relacionada ao colapso da ordem social, econômica e religiosa medieval. No movimento geral contra o feudalismo houve uma nova ênfase na existência pessoal dos homens, acima e além de seu lugar e sua função numa rígida sociedade hierárquica. Houve uma ênfase similar, no Protestantismo, na relação direta e individual do homem com Deus, em oposição a esta relação mediada pela Igreja. Mas foi só ao final do século XVII e no século XVIII que um novo modo de análise, na Lógica e na Matemática, postulou o indivíduo como a entidade maior (cf. as "mônadas" de Leibniz), a partir da qual outras categorias (especialmente categorias coletivas) eram derivadas. O pensamento político do lluminismo seguiu principalmente este modelo. $\mathrm{O}$ argumento começava com os indivíduos, que tinham uma existência primária e inicial. As leis e as formas de sociedade eram deles derivadas: por submissão, como em Hobbes; por contrato ou consentimento, ou pela nova versão da lei natural, no pensamento liberal. $\mathrm{Na}$ economia clássica, o comércio era descrito através de um modelo que supunha indivíduos separados que [possuíam propriedade e] decidiam, em alguns pontos de partida, entrar em relações econômicas ou comerciais. $\mathrm{Na}$ ética utilitária, indivíduos separados calculavam as consequências desta ou daquela ação que eles poderiam empreender (WILLIAMS, 1976, pp.135-6).
\end{abstract}

\title{
3.3 No corpo cindido
}

A sociedade moderna se mostra como um local de transformação, reformulação e questionamentos permanentes. Alteram-se as práticas de construção e verificação de identidade, bem como da cultura e da encomia social.

A transformação é permanente para estar inserido no contexto da modernidade tardia e, por isso, parece efêmera, mas não se trata do efêmero, trata- 
se do permanente ao vivo/do constante/do durante, de uma ação permanente dos corpos "instalados" (Merleau-Ponty) numa realidade comunicacional que passa a "a fazer parte do volume de nosso corpo". (MARCONDES FILHO, 2013, p.45)

Estar conectado faz com que o contato com a Internet se instale no nosso corpo emocional, penetre o nosso afeto e passe a fazer parte do volume cultural, social, memorialístico do corpo de quem entra em contato com ela. É um acontecimento único porque é ao vivo, em mutação e pressupõe um diálogo entre Usuários que são atores/produtores de informação.

Mesmo dentro de uma crise identitária constante como citado anteriormente, o Usuário está inserido nas "transformações do tempo e do espaço" (HALL, 1992), dentro de um certo "desalojamento do sistema social” na 'extração' das relações sociais dos contextos locais de interação e sua reestruturação ao longo de escalas indefinidas de espaço-tempo' (Giddens in HALL, 1992, p.21).

É nesta prática híbrida de identidades e visibilidades contemporâneas que o Usuário acontece em consonância com o que Jameson fala quando inverte o postulado althusseriano de que o sujeito "cindido" está articulado "na disjunção entre tempo e ser que caracteriza a sintaxe social da condição pós-moderna" da qual fala $\operatorname{BHABA}(1998$, p. 295):

"o colapso da temporalidade que subitamente libera esse presente do tempo de todas as atividades e intencionalidades que poderiam pô-lo em evidência e fazer dele um espaço de práxis... engolfa o sujeito com vivacidade indescritível, uma materialidade de percepção apropriadamente opressiva... Este presente do mundo ou do significante material se apresenta ao sujeito com intensidade elevada, portando uma carga de afeto misteriosos... que se poderia muito bem imaginar nos termos positivos de uma euforia, um êxtase, uma embriaguez ou intensidade alucinogênica". (JAMESON, 1991, p.27) ${ }^{35}$

\footnotetext{
35 "...the breakdown of temporality suddenly releases this present of time from all the activities and intentionalities that might focus it and make it a space of praxis; thereby isolated, that present suddenly engulfs the subject with undescribable vividness, a materiality of perception properly overwhelming, which effectively dramatizes the power of the material - or better still, the literal signifier in isolation. This present of the world or material signifier comes before the subject with heightened intensity, bearing a mysterious charge of affect, here described in the negative terms of anxiety and loss of reality, but which one could just as well imagine in the positive terms of euphoria, a high, an intoxicatory or hallucinogenic intensity."
} 


\subsection{Locais da identidade}

Nesta remontagem das identidades que parecem deslocadas pela globalização e das relações de espaço-tempo simbólicos é possível perceber que a globalização pode provocar um tipo de gentrificação do local da cultura no sentido de que destitui o sujeito comunicacional/Usuário de um local identitário em nome de uma visibilidade?

Hall se preocupa que as identidades nacionais começam a se deslocar e, por vezes, se apagar quando "colocadas ainda o nível da cultura nacional, as identificações 'globais'". Então, é pertinente a questão de que a vida social é mediada e a identidade é sempre desalojada?

Percebe-se que por gentrificação de identidades se possa entender identidades homogeneizadas, quando são limpas de todas as peculiaridades e características subjetivas que as tornam únicas. A identidade está profundamente envolvida no processo de representação. "Assim, a moldagem e a remoldagem de relações espaço-tempo no interior de diferentes sistemas de representação têm efeitos profundos sobre a forma como as identidades são localizadas e representadas". (HALL, 1992, p.71)

Assim como o capital, a internet transcende as barreiras nacionais. Tende mesmo a ignorá-las no momento de sua expansão e promove o status do capital à um bem global. Os Usuários se transportam entre fronteiras físicas e virtuais. Habitam um universo que - em tese - tenta ser global no sentido da abolição das fronteiras e simultaneamente local no sentido da comunidade, da cultura, da identidade necessária para requerer visibilidade. É habitante de um universo cultural híbrido, como quando Salman Rushdie (1991) diz que a palavra tradução vem do latim 'transferir'; transportar entre fronteiras.

Pode-se ler o Usuário como um tradutor que existe para transferir a cultura dentro de uma noção de identidade. E Hall quando fala de Rushdie, se refere ao escritor traduzido e vivendo sempre entre dois mundos, na própria dobra cultural, entre Ocidente e Oriente.

A ideia da Diáspora apontada por Hall, dos povos sempre "transportados" leva a uma situação de eterna transição e busca, experimentada pelos Usuários, habitantes de uma nação abstrata também - e porque não - fruto de um pós- 
Colonialismo que "devem aprender a habitar, no mínimo, duas identidades, a falar duas linguagens culturais, a traduzir e a negociar entre as culturas híbridas". (HALL, 1992, p.89) A população global de Usuários também constitui uma nova identidade produzida na era da modernidade tardia. Como é da sua realidade, há no Usuário um discurso híbrido e, de certa forma, duplo de cultura que ele traz na própria bagagem e publiciza na cultura do outro, o local onde se faz visível e onde encontra a identidade híbrida e a representação.

O sujeito/Usuário atua num espaço-tempo moldado para a construção de uma identidade e na busca de um lugar/local para onde está identidade o conduza. Ou, talvez, trabalhe na construção de uma identidade que ao existir de maneira plena produza um local/nação/comunidade e que, como outros mais tradicionais, também são imaginários, simbólicos e discursivos. A nação e a identidade são locais de existência e de visibilidade necessárias para que o Usuário se estabeleça e também a partir dos quais ele deseja ser visto, mesmo que seja de maneira efêmera e transitória. Então, repete a tradição de uma espécie de necessidade de pertencimento que se coloca de maneira urgente como um ponto de partida para o voo identitário que ele está sempre prestes a fazer.

\subsection{Consumidor Móvel}

O Usuário se move livremente ao mesmo tempo em que tem acesso a informações numa esfera global. E porque está conectado reflete a cidade nas redes sociais. Muito provavelmente este sujeito não faz uma leitura crítica do ambiente com a reflexão num tempo benjaminiano, mas num tempo novo, atual, diferente daquele porque exige uma interação que acontece num outro ritmo de sensações e reações.

Questões surgem como: O Usuário de mídias móveis pode ser comparado ao Flâneur de Benjamin no sentido de que possui a mobilidade para se movimentar pelo ambiente/cidade, de que se comunica com o que é transitório e estabelece um critério para esta relação com o efêmero da visibilidade das redes sociais? A intenção não é obter uma resposta fechada, mas de abrir os questionamentos e que estes possam gerar o debate mais amplo. 
O Usuário tem o tempo do Flâneur para desfrutar da cidade, do ambiente de sua escolha pelo simples fato de poder estar conectado e em contato com os ambientes virtuais que desejar.

Usuário pode estar conectado com as redes de sua preferência. As redes em si funcionam de forma gratuita como Facebook, Twitter, Instagram, Snapchat e Periscope, exemplos utilizados aqui por serem - cada uma com suas funções específicas - redes que abriram caminho para a transformação das relações sociais; possuem apelo mundial e estão entre as mais conhecidas entre todas no momento desta pesquisa.

A mídia móvel leva ao movimento, à ação do Usuário na cidade e à interação dele com outros ambientes não virtuais de maneira que as informações e experiências desses lugares sejam intercambiáveis. É de se esperar que uma experiência do ambiente de realidade não-virtual tenha uma comunicação imediata com os ambientes virtuais e redes de comunicação interpessoal, ou redes sociais.

Imediatamente e inclusive durante a experiência o Usuário tende a postar alguma informação em foto, vídeo ou texto que reflita o momento vivido para que seja compartilhado com outros Usuários. O lugar onde ele está, no que diz respeito distância geográfica, já não se torna importante. No entanto, a facilidade e o imediatismo do contato pela rede, pode se transformar em algo ainda mais atraente devido às distâncias geográficas que, em alguns casos são imensas.

A sensação do Usuário de receber uma visibilidade em qualquer lugar do planeta aproxima e se coloca como um ponto de atração determinante para quem participa seja postando ou respondendo às postagens. O que parece importante é ter a comunidade que dá visibilidade às ações na rede que constituem um dos principais modelos de visibilidade social atualmente.

Nessa chave do prazer e da performance há a percepção de um processo de "preensão" [Deleuze fala sobre os conceitos de Whitehead] (DELEUZE, 2007, p.120) da realidade que é espelhada/refletida na Internet. O Usuário desfruta das três características apresentadas por Deleuze:

"primeiramente a forma subjetiva é a maneira pela qual o datum é expresso no sujeito, ou a maneira pela qual o sujeito apreende ativamente o datum (emoção, avaliação, projeto, consciência...) (...) Em segundo lugar, a visada subjetiva assegura a passagem de um datum a outro numa preensão ou de uma preensão a outra num devir e põe o passado num presente cheio de 
futuro. Finalmente a satisfação como fase final, o self enjoyment, marca a maneira pela qual o sujeito cuida de si próprio e atinge uma vida privada cada vez mais rica, quando a preensão preenchesse com seus próprios data". (DELEUZE, 2007, pp. 120,121)

A rede social preenche os vazios, estabelece conteúdos que não permitirão a existência do oco. Ela existe presente no cotidiano e o contato acontece antes da formação dos desejos e trará na sua fluidez um devir. Uma vez que a atuação nas redes é compreendida como performance talvez seja possível afirmar também que se estabelece na noção de "envolvimento recíproco, de entrelaçamento ou de quiasma" (DUPOND, 2010, p. 10) e ser o "corpo como coisa visível contido no grande espetáculo."

O prazer/self enjoyment remete diretamente ao que é provocado pelo compartilhamento da informação no momento de sua emissão. A rede social é utilizada no tempo presente do afeto. É uma concrescência de múltiplos disjuntivos que na emissão passam a constituir uma unidade conjuntiva (o novo) que reflete o que afetou o Usuário no tempo presente e que no próximo momento irá gerar cognição dos outros Usuários que acessarem o post. O momento presente deste ato comunicacional de postar, é um movimento relacional tanto para quem o faz como para quem o recebe estabelecendo um contrato afetivo de fidelização a este ou aquele Usuário tornando-o um protagonista do visível.

É através da rede social que o Usuário se expressa e realiza desejos nem mesmos imaginados preenchendo de antemão as possibilidades de vazio ainda não criadas sem deixar espaço para que as subjetividades sejam reveladas e vivenciadas. Porque a antecipação promove ou induz a uma transformação prévia dos desejos e das subjetividades atuando diretamente nas formas de individualidade que poderiam se revelar.

$\mathrm{O}$ ato de postar é efêmero e se traduz num momento presente, tendo este mesmo ato um momento comunicacional que estabelece contato e Gestalt numa relação direta com o abstrato da Nuvem Comunicacional já vista anteriormente. A volatilidade ou o estado gasoso em que existe a concretude da Internet se revela em uma noção de facticidade que reúne em Merleau-Ponty as heranças de Kant, Husserl e Heidegger. No ambiente da cidade deste caminhante que reflete o que vê imediatamente no momento visto, o ato é fato, e a essência já não é "uma condição 
subjetiva da inteligibilidade do fato, elas é sua armação imanente, sua idealidade carnal" (MERLEAU-PONTY in DUPOND, 2010, pp.30 e 31). Ela possui uma condição de ação intrínseca que o caminhante conectado não abre mão. Ele é um ator conectado e possui uma "Fala Falante", uma fala conquistadora de novos territórios que

\footnotetext{
"ultrapassam o universo dos significados sedimentados e animada por uma intenção significativa 'em estado nascente', tenta 'por em palavras um certo silêncio' que a precede e a envolve. (...) a 'fala falada' [do Usuário] é a consequência da invenção do sentido no mundo cultural dos significados comuns disponíveis (...) ela é o momento de sedimentação da própria vida". (Idem, 2010, p. 32
} 
Capítulo 4

USUÁRIO 'AO VIVO' 


\section{Usuário 'ao vivo'}

Vive-se na era digital um tempo jamais vivido antes, que é personalizado na prática do presente. Novos códigos, comportamentos e referências são criados e estabelecidos todos os dias para um tempo sem referencial específico. Contemporâneos trazem a bagagem construída como sujeitos comunicacionais. No entanto, experimentam até mesmo uma certa melancolia do futuro, de incertezas num devir comunicacional e de um presente existente ainda que abstrato. Tais sensações e estados de ser não constituem uma situação adversa, mas um estado atual do ser e do estar em ambientes em que o comportamento é determinado na maioria das vezes pelas conexões realizadas virtualmente e pelo durante da ação comunicacional, um ato ao vivo mediado pelo computador que estabelece a vida online em formatos de dispositivos fixos ou móveis, um túnel de luz, uma nova caverna de Platão onde, segundo Rötzer comentado por Marcondes Filho, "os homens não estão presos fisicamente a corrente mas 'presos a uma encenação', sem se darem conta de que se trata de uma prisão." (MARCONDES FILHO, 2013, p.87)

Esta vida em conexão permanente é o atual e cada vez mais presente estado do ser. O virtual é o novo real e mencionar o estado virtual ou o digital de uma relação torna-se desnecessário à medida que a vida caminha rapidamente para uma conexão permanente, 24 horas por dia e sete dias por semana. Estamos, portanto, engendrando um novo ser humano que existe a partir de uma bagagem trazido desde o Observador, passando pelo Espectador e que vêm culminar no Usuário permanente, um novo tipo de soldado social que não dorme e que não desliga jamais como sugere Crary $(2014)^{36}$.

O Usuário carrega aspectos do Flâneur como se fosse um tipo de informação genética de comunicação, na medida em que ele estabelece conexões em movimento pelo ambiente físico no qual circula. Renova as posições geográficas nas combinações de algoritmos de localização. O Flanêur virtual é o novo crítico da 'cidade', de um território infinito. Reflete sobre o que vê e o que vive em postagens, textos e imagens que são a sua mais real manifestação e forma de comunicação.

${ }^{36}$ No texto $24 / 4$ - capitalismo tardio e os fins do sono. 
Ele estabelece normas de comportamento todos os dias e em cada momento uma prática audiovisual determinante de relações sociais e culturais, revela-se pelo ato de estar na rede e na visibilidade que adquire na forma como se comunica. Inova, se for o caso, ou segue, como preferência, deixando claro também que este é o seu comportamento e sua forma de ser.

Visibilidade é território no contexto da vida online e a geografia do dia a dia deixa claro a performance individual na rede. O Usuário parece buscar a liberdade do Flâneur de estar em locais nunca visitados e de criar novos lugares- blogs, sites, redes, canais, comunidades para conviver com visitantes/seguidores em permanente construção e de fruição efêmera porque podem ser extintas de acordo com os interesses e as necessidades mais imediatos.

A comunicação acontece sem roteiro, e sem que haja nenhuma possibilidade de prever suas consequências. Pesquisas de audiência, projetos, tudo pode estar previsto. O que não está previsto é a sua consequência, a reação ao ato comunicacional. Vivemos o ‘acontecimento' enquanto nos comunicamos.

Quando o assunto é mídias móveis como tecnologia, a Internet como meio, e as redes sociais como facilitadores - uma forma de um meio dentro de outro meio estamos falando de comunicação ao vivo no tempo presente. Embora Marcondes Filho não trate especificamente de meios como a Internet e redes sociais, as ideias se aplicam aqui e traduzem de maneira muito precisa o universo tecnológico da comunicação pela Internet cada vez mais metapórica no tempo presente:

\footnotetext{
"uma imagem é dinâmica se promove a ação, se não for apenas 'representação mental', algo que desmaterializa o objeto, mas efeitos que recuperam o mundo como 'provocação concreta' que solicitam a intervenção ativa e modificadora do homem". (MARCONDES FILHO, 2013, p. 59)
}

Dessa forma, o Flâneur/Usuário/ator das informações circulantes utiliza uma técnica envolvida pela tecnologia, desoculta um universo móvel em constante mutação para se relacionar com o seu universo mais próximo a ele. Trata-se de qualquer ambiente de referências e informações encontradas, discutidas e compartilhadas em rede ou não necessariamente nela. O Usuário móvel tem neste ambiente todas as oportunidades de exercer a comunicação como ator e produtor de informações a partir do seu ponto de vista. Portanto, Observador do século 21 e Usuário de meios de comunicação através da Internet talvez não esteja mais 
preocupado com o fato de que as informações sempre foram transmitidas por meios e profissionais convencionais como jornalistas, radialistas, publicitários em modelos de produtos estabelecidos.

Os novos lugares são como as Passagens de Benjamin, arcadas que descortinam uma técnica e uma tecnologia de utilização do novo universo possível. A Passagem era ambiente labiríntico onde as pessoas se acotovelavam, o mundo novo, como fala Buck-Morss (2002).

Benjamin utiliza a descrição de um guia de Paris para falar das Passagens, galerias de lojas e estabelecimentos e que são a grande novidade na cidade a partir de 1822:

\footnotetext{
"Galerias são as nova invenção do luxo industrial, são vias cobertas de vidro e com o piso de mármore, passando por blocos de prédios, cujos proprietários se reuniram para tais especulações. Dos dois lados dessas ruas, cuja iluminação vem do alto, exibem-se as lojas mais elegantes, de modo que uma dessas passagens é uma cidade em miniatura, é até mesmo um mundo em miniatura". (Guia llustrado de Paris - de 1852 - in BEJAMIN, 1985, p. 31)
}

Atualmente, a Internet é a nova Passagem, que causa o deslumbre, onde todos querem estar e assume este caráter labiríntico, enquanto que as redes sociais são os locais onde as pessoas se acotovelam.

A Internet talvez ressimule um romantismo. "No século 20, Benjamin disse que a "nova natureza" da cultura industrial tinha gerado todo o poder mítico para um "simbolismo universal" que esses românticos poderiam desejar. A "nova natureza" de Benjamin está presente na nova cultura industrial com o poder mítico de um simbolismo universal reificado. Os novos deuses digitais que podem ser pessoas, criadores, atores da rede, os que ocupam o lugar de visibilidade, substituem os deuses antigos. A crítica de Buck-Morss se dá em relação às novas deificações quando diz que "não é a presença dos deuses que deve ser deplorada, nem o seu novo caminhar nesta terra, mas a tentativa de construir uma morada permanente para eles" (BUCK-MORSS, 2002, p.306). Porém, lembra que Benjamin valorizava a presença dos deuses como "um sinal auspicioso" que "augura uma mudança social". (Idem, p. 305) E que "os deuses são parciais a esse espaço de transição ao despertar que hoje vivemos". Portanto, não parece equivocada a ideia de novos 
deuses digitais habitantes de um ambiente "intoxicado" 37 pelo moderno quando assume o papel de novidade, mas sem abrir mão do que se revela com a Modernidade.

Assim como o Usuário se forma a partir de um lugar de consumo, o Observador também acontece a partir de um certo olhar e de um olhar que será destinado ao consumo. Um movimento similar em que ambos partem de um mesmo pressuposto de informação: o uso do tempo livre das massas num contexto capitalista, seja ele tardio ou não.

Há um devir na relação do Observador/Usuário com a tecnologia que impõe uma técnica de descortinar/desocultar a relação com a mídia social e gerar oportunidade de atuação nesse meio e ser um produto de conteúdo. O prazer da atuação passa por uma sensação de inclusão, de oportunidade e de pertencimento. Portanto parece pertinente quando Buck-Morss fala que a cultura capitalistaindustrial possui uma contradição fundamental,

"um modo de produção que privilegiava a vida privada e baseava sua concepção de sujeito no indivíduo isolado tinha criado formas completamente novas de existência social - espaços urbanos, formas arquitetônicas, mercadorias produzidas em massa e experiências individuais infinitamente reproduzidas - que engendravam identidades e conformidades nas vidas da pessoas, mas não a solidariedade social, nem um nível novo de consciência coletiva em torno de algo em comum (sua comunidade) e logo nenhuma maneira de despertar do sonho em que se envolviam". (Idem, pp 310-311)

O consumo em rede digital/tecnologia é um consumo de renovação constante. "Cada época sonha a seguinte" (Michelet. Avenir! Avenir!), como lembra Benjamin e há uma necessidade de "se distinguir do antiquado - mas isto quer dizer: passado recente" (Benjamin, 1985, p.32) e de reconfigurar a vida. Benjamin observa que "evita-se o ferro nas moradias, mas ele é empregado nas galerias, salas de exposições e estações de trem - construções que serviam para fins de trânsito". (Idem, p.32) O material utilizado para construções com finalidades de trânsito indica uma necessidade de mobilidade e porque não de transitoriedade. Uma transitoriedade que abre oportunidades no tempo atual do Observador em trânsito, do Usuário móvel que participa de uma nova realidade técnica e social. "Depositadas no inconsciente da coletividade, tais experiências, interpenetradas pelo

\footnotetext{
${ }^{37}$ Benjamin fala do moderno que intoxica (1985).
} 
novo, geram a utopia que deixa o seu rastro em mil configurações da vida, desde construções duradouras até modas fugazes". (Ibidem, p.32)

A transitoriedade do tempo contemporâneo não parece muito distinta da transitoriedade de um século 19, o Observador em trânsito é o Usuário em trânsito e este parece o tempo todo perguntar: Qual é a próxima novidade? A nova rede social, o novo aplicativo que vai me dar a oportunidades de ampliar o tempo presente ao vivo - o acontecimento comunicacional - o campo de atuação para coisas que eu ainda não fiz. Qual é a próxima novidade que eu nem sabia que iria /gostar/precisar/depender tanto?

O Flâneur quando passa pelas galerias, pela cidade descortinada para o olhar, apreende as informações da vida e desoculta a relação com 0 ato comunicacional. Quando comenta Levinas, Marcondes Filho enfatiza que "o dizer vem antes das diferenciações, não sendo verbo, nem substantivo, ele é 'o ferimento', não a ferida". (MARCONDES FILHO, 2013, p. 69)

Este dizer pressupõe o ato de estar e viver a comunicação na sua plenitude imediata. A narração sempre vem depois do ato comunicacional. E é uma forma de contar o presente recém-vivido. Mesmo que todos os relatos estejam sempre aquém das vivências, como enfatiza Marcondes Filho, o Flâneur contemporâneo/sujeito da comunicação privilegia o instantâneo no mesmo instante em que posta e compartilha a experiência no presente em que ela acontece: "o dizer está no campo da experiência em ato, ele é suas vibrações, energias presentes, tensões, frissons, é vivência pura, mas, como tal, intransmissível". (Idem, p.69) E fala de uma impossibilidade desse aquém entre os relatos e as vivências relacionado a um campo etnográfico em relação ao Metáporo. Com esta ideia mostra que a reflexão da comunicação pertence a um passado e a outras formas de se comunicar e que o ato de dizer e de ser dito nas redes sociais provoca uma certa perturbação nessa ideia.

Houve o momento em que o homem foi deslocado do centro para a margem no declínio do antropocentrismo que começa com a Modernidade. A realidade medial, que se sobrepõe à realidade usual, acontece no final do século 19 e início do século 20 acompanhada de uma "virada comunicacional" se dá quando o homem atua nesse deslocamento abandonando o centro onde não se "instala uma máquina, 
mas as imagens, os sons e as escritas do mundo". (MARCONDES FILHO, 2013, p. 79)

É importante lembrar que este fenômeno vai levar à sociedade do espetáculo nos primeiros anos do século 20, também pensada por Adorno e Horkheimer em seu exílio nos Estados Unidos quando tratam a produção de cultura como um "clima". Os autores determinam que a produção cultural, na essência, é como uma fuga do cotidiano que deságua na sedução do espetáculo das mercadorias e das imagens que estarão impressas para sempre nas mentes e farão parte da cultura a partir do ato comunicacional que infligem nos cidadãos. $E$ reafirmam que produções da indústria cultural como filmes, encenações, parques, circos, e depois o Rádio e a Televisão são instrumentos responsáveis pelo desvio do real.

O homem da Modernidade de Marcondes Filho percebe que se ampliam os horizontes do sujeito na midiática sociedade do espetáculo com as descobertas técnicas de amplo alcance social como a "fotografia, máquina de escrever, rotativa, fonógrafo, cinematógrafo, mas também a alfabetização geral da sociedade, da expansão da cultura literária e do ensino público ser assumido pelo Estado" (MARCONDES FILHO, 2013, p.85). A sensibilidade humana se altera de maneira definitiva e os sistemas técnicos registram o mundo ao redor e uma "realidade medial específica passa a se constituir ao lado de uma realidade convencional". (Idem)

Levanta a questão sobre o homem "está sendo engendrado" na era digital se mantém pertinente. E coloca que o projeto de mundo Moderno que privilegiava o poder da palavra e do livro na formação e tem os atos comunicacionais "despersonalizados":

\footnotetext{
"a caligrafia desaparece com a máquina de escrever e com o processador de texto do computador, personalidade artística de um pintor dilui-se na captação fotográfica da realidade, os aparelhos de gravação de som fixam uma voz que tinha a característica de ser fugaz e dissolver-se no ar. Os traços humanos desaparecem da comunicação". (Idem, p. 86)
}

Os aparelhos de registro e reprodução criam novas sensibilidades na Modernidade e, agora, na era digital, também novos sujeitos comunicacionais com uma bagagem cultural/afetiva e caminhando sobre os passos dos sujeitos anteriores a ele. Eles estabelecem contato com a tecnologia e desenvolvem saberes nos dias 
atuais e futuros. O homem está sendo refeito, repensado e o Usuário em movimento se expressa através da tecnologia, escrevendo uma nova geopolítica com as atuais e futuras formas de colonização trazidas pela Internet.

As sempre novas oportunidades são também "imagens do desejo de superar as carências do produto social" (Idem, p.32) com novos estímulos. O tempo da duração das coisas atuais pode parecer efêmero se comparado ao tempo de duração de algo no século 19, mas cada velocidade tem sua época e produz um estranhamento a quem viveu a época anterior.

Os estímulos produzem as oportunidades. Benjamin se refere às exposições universais que se tornaram um "centro de peregrinação ao fetiche mercadoria", onde os operários seriam o público-alvo e quando ainda "não se formara o quadro da indústria da diversão. Este espaço é ocupado pela festa popular". (BENJAMIN, 1985, p.35) Para Benjamin as exposições

\footnotetext{
"transfiguram o valor de troca das mercadorias. Criam uma moldura em que o valor de uso da mercadoria passa para segundo plano. Inauguram uma fantasmagoria a qual o homem se entrega para se distrair. A indústria de diversões facilita isso, elevando-o ao nível da mercadoria. O sujeito se entrega às suas manipulações desfrutando a sua própria alienação e a dos outros".(Idem, pp.35-36)
}

O Observador também se forma a partir desse novo local de consumo e com o mesmo material de informação que constitui o Flâneur. É quando a percepção conduz à ideia de que o Observador e o Flâneur são o mesmo sujeito ou que, pelo menos, compartilham da mesma matéria-prima que é o espetáculo no seu sentido mais amplo: espetáculo de fantasmagoria e distração de Benjamin.

A Internet é a fantasmagoria contemporânea e o Usuário/Flâneur que "busca asilo na multidão" ao mesmo tempo em que busca visibilidade nela. Benjamin busca recursos em Poe e Engels sobre a fisionomia na multidão que na

\footnotetext{
"cidade costumeira acena ao Flanêur enquanto fantasmagoria. Na multidão, a cidade é ora paisagem, ora ninho acolhedor. A casa comercial constrói tanto um quanto outro, fazendo com que a flânerie se torne útil à venda de mercadorias. A casa comercial é a última grande molecagem do flâneur. Com o flâneur, a intelectualidade parte para o mercado". (Ibidem, p.39)
}

Está numa situação transitória entre a cidade grande e a classe burguesa, num "limiar" destes dois universos com uma indefinição política como consequência 
de uma indefinição econômica e conectando mais do que nunca a política e a economia como interdependentes.

O Flâneur serve ao comercial porque vive na fantasmagoria de um ambiente tecnicamente armado. Por "armação" utiliza-se aqui o conceito de Heidegger:

\begin{abstract}
"Na armação acontece o descobrimento, segundo o qual o trabalho da técnica moderna desabriga o real enquanto subsistência. Ela não é, por isso, nem um fazer humano nem um mero meio no seio de tal fazer. A determinação somente instrumental, antropológica, da técnica torna-se, em princípio, ilusória; ela não se deixa simplesmente completar com um esclarecimento metafísico ou religioso colocado em sua base. Contudo, a verdade é que o homem da era da técnica é desafiado de um modo especialmente claro para dentro do desabrigar. Tal fato se refere, primeiramente, à natureza como um depósito caseiro de reservas de energias. Correspondendo a isso, a postura requerente do homem mostrase, em primeiro lugar, no surgimento da moderna e exata ciência da natureza. (HEIDEGGER, 2007, pp 385-386)
\end{abstract}

É Heidegger quem questiona se o desabrigar acontece "num além a todo fazer humano". E conclui que "não somente no homem e decididamente não por ele".

O Usuário é um sujeito em permanente desafio de abrigo, de consumo, de visibilidade. É o homem desafiado de Heidegger que transita por um ambiente armado porque está em permanente estado de requerer e "enquanto desafiar no requerer, a armação envia num modo de desabrigar. A armação é um envio $<$ Schickung $>$ do destino, assim como todo modo de desabrigar. Destino, neste sentido, é também um produzir". (HEIDEGGER, 2007, p.388)

O Usuário está sempre no caminho da descoberta, numa jornada de novidades e num destino de desabrigar que "sempre domina os homens". Heidegger coloca que o homem apenas é livre quando pertence ao âmbito do destino. 0 Usuário tem, assim, a possibilidade de se situar como um sujeito livre dentro de um cenário comunicacional. No entanto, parece que na atual configuração de uma vida regida pela Internet, ele não se torna totalmente livre, mas de uma liberdade relativa, condicionada às opções oferecidas pelos sites, canais e serviços. O Usuário tem tudo para ser livre, mas ainda não vive um desabrigar pleno - ou talvez viva plenamente uma liberdade que sabe existir, a liberdade que conhece e que para si é o suficiente - porque o "desabrigar surge do que é livre, vai para o que é livre e leva para o que é livre". (Idem, p.388) 
O desabrigar atual da liberdade da vida online se estabelece através de acordos e de pressupostos que preveem regras de comportamento. Talvez a liberdade relativa do Usuário seja a do livre armado porque a "essência da técnica moderna repousa na armação" (p.388) e ele é detentor da técnica que desabriga a tecnologia em favor de sua própria experiência comunicacional. Ele atua online de maneira perene num ambiente que aparenta ser de permanente armação, intrínseco em desafios que proporcionam um descortinar constante, num movimento de sonhar sempre o momento seguinte, a pergunta, a resposta, a atenção permanente do Usuário sem que haja descanso, moldando novas formas de pensar e de ser.

A experiência de massa é uma experiência de conformidades e de contratos afetivos que desembocam no negócio principal do capitalismo que é a produção e o escoamento comercial desta produção. Hoje estes produtos são determinados pelos acessos que recebem. Dentro de um contexto de uso de bens e atuação nas redes, - Usuário parece ser uma evolução natural do Observador. O capitalismo e a as experiências de massa tendem a estabelecer que 0 interesse pelo Usuário/Consumidor e sua individualidade ocupam um lugar de destaque nas novas formas de circulação de bens e mercadorias tanto simbólicas e abstratas, quanto concretas. Estabelece-se uma economia de gestos, comportamentos e atitudes, determinantes para a nova economia em questão, numa trajetória percorrida aparentemente para alcançar apenas este objetivo.

Olhando para o futuro talvez um exercício possível seja o de que a deificação da vida online venha a ser uma forma de pertencimento deste momento da comunicação, porque tudo o que se tem é o presente. Pode haver um passado na memória das postagens, mas o futuro é imprevisível e o presente existe de fato num ambiente em que a ação é a participação, é o click na página. Deificar seria o universo idealizado no olimpo efêmero da vida na rede.

Há camadas de percepção sobre a movimentação do Usuário. Há o local físico de onde fala e pertence originalmente e um local de cultura para ele. No limiar de um mundo onírico que ainda não sabe bem o que fazer e onde estar, estes podem ser questionamentos.

$\mathrm{O}$ 'onde estar' pode ser compreendido como 'qualquer lugar'. A origem localizadora serve como atitude geopolítica para a produção de novos serviços e 
ofertas e gera visibilidade de informação sobre o Usuário. No entanto, a Internet é o Lugar, o novo 'Local da Cultura' do Usuário e é, ao mesmo tempo, a Passagem.

O dispositivo móvel que ele carrega consigo é a Passagem. A movimentação física pela cidade/ou o estar numa sala ou quarto acessando a rede descortina um caminho que recebe uma nova carga de informação e se alimenta dele. A navegação é o movimento que está ao lado do físico e pode ser sobrepor a ele em importância com a permanente necessidade de atenção do Usuário/receptor/emissor e de resposta. Um pensamento em consonância com a reflexão da pesquisadora Janice Primo Barcellos (2018) quando diz que "a Passagem hoje caminha como Usuário". Diferente do momento em que o público tem que ir até a Passagem para o consumo e o convívio, o Usuário hoje leva a Passagem consigo no dispositivo móvel, é o portador do mundo novo tem uma necessidade de pertencimento seja premente e durável.

Ver e ser visto se refere à própria ambiguidade da imagem visível e de uma visibilidade dialética que o Usuário busca, ao que Benjamin chama de um "estado de paralisação" utópica. Para ele,

\footnotetext{
"a imagem dialética é uma quimera, a imagem de um sonho. Tal imagem é presentificada pela mercadoria enquanto fetiche puro e simples. Tal imagem é presentificada pelas passagens e galerias, que são tanto casa quanto rua". (BENJAMIN, 1985, pp. 39-40).
}

O Usuário se move pela cidade utilizando as redes sociais para estabelecer relacionamentos e, como um Flâneur, ele usa a cidade como casa, ambiente-habitat que frequenta, por onde circula e vive. $\mathrm{O}$ uso da cidade para além das ações do cotidiano contém/inclui também uma ação de relacionamento estabelecido através das redes sociais - as novas cidades do Usuário - refletida e comunicada nos posts. Ganha visibilidade quando as postagens são acessadas e compartilhadas gerando um processo comunicacional total no sentido de que há um ciclo de uma mensagem a ser levada até um receptor.

Ele comunica a cidade por onde passa ou qualquer uma de suas ações em tempo real. E por ser em tempo real, é também ao vivo - como quando são feitas as transmissões televisivas ou de outros meios de comunicação em streaming - o que produz um acontecimento comunicacional no tempo presente. No que diz respeito à ideia de compartilhamento a captura de informações se dá exatamente 
"quando damos alguma importância a algo que vemos, ouvimos, percebemos do ambiente externo, ou seja, quando efetivamente fazemos uma seleção, uma triagem em que separamos algo em que queremos nos envolver, seja por vontade própria, seja por alguma armadilha que nos faça voltar a coisa mesmo sem intenção" (MARCONDES FILHO, 2013, p. 22),

como nos faz crer Marcondes Filho a respeito do ato comunicacional. E a define como "uma afecção que desestabiliza a função cerebral de acoplamento a uma memória anterior que seria tranquilizante. Ela cria memória”. (Idem) 
Capítulo 5

USUÁRIO: FLANÊUR e DÓCIL 


\section{Usuário: Flanêur e Dócil}

Em um de seus primeiros posts de 2018 em sua principal rede social, o criador e dono do Facebook, Mark Zuckerberg disse que o foco deste ano é "garantir que o tempo que todos nós passamos no Facebook seja um tempo bem gasto..."38.

Seria este um "tempo bem gasto" como recompensas para que os Usuários do Facebook não se frustrem com os posts ruins, notícias falsas ("fake news"), vídeos desnecessários? Ou seria o tempo despendido em busca de preencher um vazio interior que se constrói a partir do hábito de acessá-la com frequência, como se o Usuário esperasse algo que está para acontecer, desejasse ou necessitasse de um fato para completar lacunas deixadas pelo acesso constante às redes. Cria-se uma expectativa, ansiedade, um devir que pode nunca se realizar e mais frustra do que preenche vazios: navegando de post em post, acessando muitos lugares ao mesmo tempo, buscando e aguardando likes, respostas, aceitações e pertencimentos. Além do acesso à informação, isto é o que as pessoas geralmente buscam na rede e nas redes sociais em particular. Atuam na chave do mimético desejando o que os outros desejam.

O Facebook parte do princípio de que para se relacionar, todos compartilham de desejos semelhantes. Na vida onde o espetáculo/novidade extingue limites da subjetividade acontece o que Debord chama de "supressão dos limites do verdadeiro e do falso pelo recalcamento de toda a verdade vivida sob a presença real da falsidade que a organização da aparência assegura". (DEBORD, 2003, p. 164) E o consumo e o reconhecimento das mercadorias "estão no centro desta pseudo-resposta de uma comunicação sem resposta". Para ele, o consumidor sente necessidade de imitar de uma maneira infantilizada e "condicionada por todos os aspectos da sua despossessão fundamental". (Idem, p. 164) Estamos tratando do mesmo Usuário/Flanêur consumidor e 'crítico da cidade' e das suas novidades. Muitas pessoas desejando o mesmo juntas com o objetivo intuitivo e emocional de pertencimento que proporcionam a sensação de necessidade, desenham juntas uma

38 "Continuing our focus for 2018 to make sure the time we all spend on Facebook is time well spent..." Postado em19 de janeiro de 2018. [tradução desta autora]

Disponível em: https://www.facebook.com/zuck

Acessado em 21 de março de 2018. 
das chaves do mercado publicitário.

O que o Facebook busca declaradamente pelo menos depois da abertura de capital na bolsa de valores dos Estados Unidos é monetização e crescimento. Utiliza os dados dos usuários para fornecer informações aos anunciantes, que muitas vezes entram nos e-mails pessoais ou nas páginas de busca como se fossem um post amigo ou um alerta de compras que interessa. Afinal, "nada influencia mais que a recomendação de um amigo de confiança. Uma recomendação de confiança é o Santo Graal da publicidade", ${ }^{39}$ foi o que escreveu Zuckerberg no Facebook Ads, a plataforma do Facebook usada para gerir e direcionar anúncios.

Tempo é o que se gasta quando se utiliza a Internet. Passa-se o tempo em contato com redes sociais, comunidades, grupos, sites, blogs, buscas, jogos, fóruns e todas as outras possibilidades e combinações delas. Em 2014, o New York Times fez o cálculo e concluiu que, de acordo com o Facebook - que na época tinha 1 bilhão e 230 milhões de usuários - cada um deles passava em média 17 minutos por dia conectado na rede social.

"Ao todo, significa mais de 39 mil 757 anos do nosso tempo gastos coletivamente no Facebook em um único dia. $\mathrm{E}$ isto em apenas um website. Vários relatórios estimam que as pessoas entre 18 e 34 anos de idade passam até 3,8 horas por dia em mídias [redes] sociais. E atualmente os que tem entre 35 e 49 anos de idade não melhoram muito essa marca, atingindo 3 horas por dia em sites sociais". ${ }^{40}$

Segundo o artigo, se levarmos em conta que o dia tem 24 horas e que uma pessoa dorme cerca de oito horas, cerca de $1 / 16$ do tempo em que passa acordado é usado no Facebook que é apenas uma rede social entre tantas outras. Em 2016 os usuários do Facebook nos Estados Unidos tinham aumentado esta marca para

\footnotetext{
${ }^{39}$ Disponível em: https://www.facebook.com/business/products/ads Último acesso em 22 de março de 2018.

40 "According to Facebook, the company's 1.23 billion users log into the site for an average of 17 minutes each day. In total, that's more than 39,757 years of our time collectively spent on Facebook in a single day. And that's just one website. Numerous reports estimate that 18-to 34-year-olds spend as much as 3.8 hours a day on social media. These days 35 to 49-year-olds don't fare much better, racking up 3 hours a day on social sites." [tradução desta autora]

Em Reclaiming Our (Real) Lives From Social Media, de Nick Bilton.

Disponível em:

https://www.nytimes.com/2014/07/17/fashion/reclaiming-our-real-lives-from-social-media.html Último acesso em 22 de março de 2018.
} 
50 minutos por dia. ${ }^{41} \mathrm{Ou}$ seja, em dois anos esse tempo foi triplicado. Não está sendo computado aqui o tempo que o Usuário passa em outras redes sociais como Instagram ou Whats App, por exemplo.

$\mathrm{E}$ tanto tempo gasto exige aquela que, talvez, seja uma das mercadorias mais valiosas do nosso tempo: atenção. Para compreender de que atenção se fala, acredita-se que seja importante compreender antes a sensibilidade e olhando três autores que dialogam entre si e com esta pesquisa: Deleuze, Berardi e Foucault.

Deleuze escreveu em seu livro sobre Francis Bacon que "sensibilidade é vibração" e diz que num corpo ainda sem forma, num ovo, a sensibilidade se revela antes de uma representação orgânica: "eixos e vetores, gradientes, zonas, movimentos cinemáticos e tendências dinâmicas..." (DELEUZE, 1981, p.45) Os corpos ainda sem forma podem ser de certa maneira "ocupados" por estímulos que irão moldar sensações e comportamentos, São corpos prontos para a experiência. É com esta leitura que Berardi, discorre sobre o desenvolvimento da sensibilidade e primeiro coloca como a

\begin{abstract}
"faculdade que habilita o organismo a processar signos e simulações semióticas que não podem ser verbalizadas ou codificadas verbalmente. Alguém que não seja capaz de compreender humores, emoções, alusões o não dito - uma grande parte do que constituía comunicação e que afeta diariamente a vida social - comumente se diz que é falta de sensibilidade". ${ }^{42}$ (BERARDI, 2015, p.35)
\end{abstract}

Recentemente Berardi trabalha com três ideias: $A$ impotência que nos impede de descrever o presente; a possibilidade como uma força crescente do conhecimento; e o poder que é uma máquina de tornar as pessoas invisíveis, de organização da visão, quando diz que a partir das estruturas de poder, "nós somos capazes de ver algumas coisas e incapazes de ver outras" 43 , porque o poder nos

\footnotetext{
${ }^{41}$ Disponivel em: https://www.nytimes.com/2016/05/06/business/facebook-bends-the-rules-ofaudience-engagement-to-its-advantage.html Último acesso em 22 de março de 2018.

${ }^{42}$ Tradução desta autora. Todas as traduções dos textos de Franco 'Bifo' Berardi, seja em palestras em vídeo, textos eletrônicos ou impressos, são a partir das publicações em língua inglesa.

${ }^{43}$ Palestra Futurability - The Age of Impotence and the Horizon and Possibility, proferida em 25 de maio de 2017 e publicada em 31 de maio de 2017 no Institute of Contemporary Arts (ICA), de Londres. Tradução desta autora.

Disponivel em: https://www.youtube.com/watch?v=licAVwkw2zM

Último acesso em 22 de março de 2018.
} 
permite ver apenas o que deseja que seja visto. Este jogo de poder trata de algumas questões profundas que estão disponíveis, mas não são tratadas nesta pesquisa por conta de estar voltada para outras preocupações. No entanto, é inevitável estabelecer a relação com as listas de opções dos serviços de Internet. O Usuário utiliza opções fornecidas pelos produtores de informação e durante o acesso deixa claro as suas preferências que serão atendidas, ou não, a partir do ponto de vista e da ação de quem tem o poder sobre este material. Há a possibilidade de troca de sites, serviços e redes sociais, que se tornam algumas das opções do Usuário. Outras alternativas residem em produzir o seu próprio material.

Para Foucault com quem Berardi dialoga, a sensibilidade pertence ao âmbito da episteme como "a estruturação da percepção social que reforça a projeção unitária do mundo e leva à disciplina social". (FOUCAULT, 1999 in BERARDI, 2015, p. 38) Os corpos podem ser habitados por estímulos, vibrações, forças, ideias e serão moldados à maneira dos sistemas sociais que determinam formas de controle. Para Foucault é possível trabalhar o corpo em três esferas: em escala "detalhadamente; exercer sobre ele uma coerção sem folga, de mantê-lo ao mesmo nível da mecânica - movimentos, gestos, atitude, rapidez: poder infinitesimal sobre o corpo ativo" (FOUCAULT, 1977, p. 126); em objeto onde já não têm mais importância os elementos do comportamento ou a linguagem o corpo, "mas a economia, a eficácia dos movimentos, sua organização interna; a coação se faz mais sobre as forças do que sobre o sinais: a única cerimônia que realmente importa é a do exercício." (Idem.) E, por fim, em modalidade quando a correção se dá de forma "ininterrupta e constante" e quando a preocupação com os processos é ainda maior do que com os resultados destes. Os resultados deverão ser impecáveis, mas só o serão se houver sucesso nos processos. O poder é exercido de "acordo com uma codificação que esquadrinha ao máximo o tempo, o espaço, os movimentos". São métodos de controle do corpo e "sujeição constante de suas forças e lhes impõe uma relação de docilidade-utilidade, são o que podemos chamar as 'disciplinas'." (Ibidem.)

Os esquemas de docilidade determinados por Foucault demonstram as formas de maquinaria do poder que estabelecem a sujeição do indivíduo a um determinado processo com a disciplina sendo a "anatomia política do detalhe" (Idem, p.128) que se volta para a construção de um tempo útil na sua totalidade. $\mathrm{O}$ tempo 
"bem gasto" do qual fala Zuckerberg é o tempo útil, aquele que não pode ser desperdiçado e deve ser sempre monetizado.

$\mathrm{Na}$ Internet o tempo útil acontece de maneira permanente. É um encontro entre o Usuário e o seu centro disciplinar eterno. Já não apenas fisicamente, mas mentalmente. O físico tem que ter disposição para a atividade: passar horas em frente a uma tela, um dispositivo, seja sentado ou em pé, parado ou caminhando, dirigindo, trabalhando. Quando Foucault discorre sobre o controle da atividade falando do horário; da elaboração temporal do ato; do corpo e os gestos postos em correlação; da articulação do corpo-objeto e da utilização exaustiva, afirma que o poder se coloca por inteiro e ocupa toda a superfície que estiver entre o corpo e o objeto manipulado, penetra e é penetrado construindo um ambiente de aderência total entre Usuário e dispositivo. E ele vai além ao falar de coerção:

\begin{abstract}
"constitui um complexo corpo-arma, corpo-instrumento, corpo-máquina. Estamos inteiramente longe daquelas formas de sujeição que só pediam ao corpo sinais ou produtos, formas de expressão ou o resultado de um trabalho. A regulamentação imposta pelo poder é ao mesmo tempo a lei de construção da operação. E assim aparece esse caráter do poder disciplinar: tem uma função menos de retirada que de síntese, menos de extorsão do produto que de laço coercitivo como aparelho de produção". (FOUCAULT, 1977, p. 139)
\end{abstract}

Diante do que disse Foucault, é possível perceber que a atual moldagem do corpo em função do uso dos dispositivos eletrônicos como games e smartphones, pede posturas antes não exigidas com o objetivo de dedicar toda a atenção ao ato de responder às demandas. O que se exige dele aqui é atenção, a perseverança da atenção para responder às demandas do ambiente que frequenta. São novas técnicas de apropriação do tempo, que determinam as "relações do tempo, dos corpos e das forças; para realizar uma acumulação da duração; e para inverter em lucro ou em utilidade sempre aumentados o movimento do tempo que passa". (FOUCAULT, 1977, p. 142)

É a organização de durações rentáveis - em 1667 era a fábrica de Gobelins e depois em 1737 a escola de Gobelins, hoje Google e Facebook - que exigem tempo e atenção para respostas rápidas, aquisições, compras por impulso, reações às postagens, anúncios, ações multitarefas, que monetizam a duração do tempo e da atenção. Estamos diante de um momento em que a imensa fortuna em forma de tempo e atenção é fornecida de graça com a participação dos Usuários para as 
redes sociais e demais ambientes virtuais comandados por corporações que determinam a circulação de valores, símbolos e informações e modelam as novas formas de vida do século 21 através dos seus respectivos negócios.

Para concluir este primeiro raciocínio é necessário utilizar mais um vez Foucault quando aponta que a disciplina produz quatro características da individualidade a partir dos corpos controlados por ela:

\begin{abstract}
"é celular (pelo jogo da repartição espacial), é orgânica (pela codificação das atividades), é genética (pela acumulação do tempo), é combinatória (pela composição de forças). E para tanto, utiliza quatro grandes técnicas: constrói quadros; prescreve manobras; impõe exercícios; enfim, para realizar a combinação de forças, organiza 'táticas'. A tática, arte de construir com os corpos localizados, atividades codificadas e as aptidões formadas, aparelhos em que produto das diferentes forças se encontra majorado por sua combinação calculada é sem dúvida a forma mais elevada da prática disciplinar." (FOUCAULT, 1977, p. 150)
\end{abstract}

\title{
5.1 Colonização da sensibilidade $24 / 7$
}

É provável que a tecnologia se desenvolva numa rapidez muito superior à mente humana e às adaptações que o ser humano precisa atender para se tornar 'maquinal' o suficiente e suprir as necessidades orgânicas da máquina - não deveria ser o contrário?

A expansão do espaço cibernético ${ }^{44}$ que implica "na aceleração do tempo cibernético, tem efeitos patológicos nos terminais vivos, na mente humana com os seus limites físicos emocionais e culturais"(BERARDI, 2015, p. 42) ${ }^{45}$, é uma preocupação de Berardi quando fala que as multitarefas exigem mudanças rápidas entre estruturas de informação. De acordo com ele, a mente humana parece apropriada para a realização de várias tarefas simultâneas mas, no entanto, ao fazer

\footnotetext{
${ }^{44}$ Cibernética é a ciência da comunicação e da teoria do controle que diz respeito especialmente ao estudo comparativo dos sistemas de controle - como o sistema nervoso, cerebral e sistemas de comunicação eletro-mecânicos.

Disponível em:

https://www.merriam-webster.com/dictionary/cybernetics

Último acesso em 19 de fevereiro de 2018.

${ }^{45}$ Tradução desta autora.
} 
isto "dispara uma mutação psicológica, produzindo novas formas de sofrimento mental como pânico, distúrbio de déficit de atenção, esgotamento físico e mental ${ }^{46}$, exaustão mental e depressão". ${ }^{47}$ (Idem).

Vive-se atualmente num universo cíclico e opressivo de socialização forçada: para produzir e trabalhar é necessário estar conectado e estar conectado significa trabalho. Portanto, alguém conectado, mesmo que por diversão está trabalhando ao fornecer informações sobre qualquer ação em rede. Toda e qualquer informação pode ser utilizada pelas corporações, sites e aplicativos para o desenvolvimento de estímulos em suas interfaces, produtos e anúncios de produtos. Berardi diz que "a obsessão econômica traz uma permanente mobilização de energia produtiva". (BERARDI, 2015, p. 42) E traz Crary dizendo que "esta é a forma do progresso contemporâneo - a conquista incansável e controle do tempo e da experiência". (CRARY in BERARDI, 2015, p. 42). A atenção se torna um produto raro quando não se tem mais tempo para ter atenção, uma vez que quase não há tempo para tomar decisões. As informações chegam de uma maneira cada vez mais automática. Por isso, Berardi prevê que seremos governados por decisões que não respondem a estratégias racionais de longo prazo, mas por simples alternativas binárias.

O semiocapitalismo ${ }^{48}$ é baseado, segundo Berardi, em uma constante exploração da energia mental, e a competição que constitui a forma geral das relações no precário mercado de trabalho, o sofrimento mental se tornou epidêmico.

\footnotetext{
${ }^{46} \mathrm{O}$ autor cita Burnout neste trecho que é também uma Síndrome que leva este nome. "A síndrome de Burnout, ou síndrome do esgotamento profissional, é um distúrbio psíquico descrito em 1974 por Freudenberger, um médico americano. (...) sua principal característica é o estado de tensão emocional e estresse crônicos provocado por condições de físicas, emocionais e psicológicas desgastantes. A síndrome se manifesta especialmente em pessoas cuja profissão exige envolvimento interpessoal direto e intenso.

Disponível em: https://drauziovarella.com.br/doencas-e-sintomas/sindrome-de-burnout/ Último acesso em 22 de março de 2018.

47 Tradução desta autora.

${ }^{48}$ Para uma compreensão do Semiocapitalismo, recomendo a leitura do artigo de Richard Foster sobre o livro de Berardi. Neste trecho, uma breve ideia: "O nível de predomínio do capital financeiro na atualidade é esmagador e constitui o eixo central da acumulação contemporânea, até praticamente reduzir a produção de objetos materiais ou imateriais à periferia na busca de rentabilidade. O semiocapitalismo [capitalismo semiótico] se tornou o ponto máximo de abstração do capital, impactando direta e fulminantemente sobre indivíduos que vivem, cada vez mais, no interior de realidades virtuais e sob o signo da desmaterialização dos vínculos intersubjetivos".

Disponível em:

http://www.ihu.unisinos.br/78-noticias/570100-o-semiocapitalismo

Último acesso em 22 de março de 2018.
} 
Para ele, a principal fonte de patologias atualmente é a competição na área da relações interpessoais. Os sintomas individuais desta epidemia são o estresse constante com a atenção e a redução do tempo disponível para o afeto, que gera, por exemplo, solidão, miséria existencial, angústia, pânico e depressão. Neste sentido, a psicopatologia e a economia estão cada vez mais ligadas. E coloca que "na transição para o semiocapitalismo, o sofrimento mental não diz mais respeito a uma pequena minoria de gente estranha, mas tende a se tornar a norma num sistema que é baseado na exploração do precário trabalho cognitivo". (BERARDI, 2015, p. 46)

Assim, como desde o final do século 19 o que importava para o poder institucional era que a percepção funcionasse de modo a assegurar um sujeito produtivo, controlável e previsível que fosse adaptável e capaz de se integrar socialmente - como coloca Crary -, a contemporaneidade exige do Usuário um tipo de atenção que aparenta ter o mesmo objetivo de então. A Internet e seus usos se delineia num campo semelhante aos das práticas de atenção que "oferece uma superfície única heterogênea onde objetos discursivos, práticas materiais e artefatos de representação não ocupam estratos qualitativamente diferentes, mas estão envolvidos por igual na produção de efeitos de poder e novos tipos de subjetividade" (CRARY, 2013, pp. 30 - 31).

Além de construir a figura do Observador e de tratar da atenção na vida moderna, Crary traz a teoria do 24/7, fundamental para esta pesquisa. 24/7 é a abreviação de vinte e quatro horas por dia, sete dias por semana utilizada geralmente nos Estados Unidos e que se refere aos expedientes intermitentes de trabalho e de fornecimento de serviços. ${ }^{49}$ A Internet atua na frequência do $24 / 7$ e é pensada para tal: tudo está online o tempo todo. $E$ porque tudo está sempre à disposição, o Usuário também está conectado 24/7, não importando o local de onde fala. A conexão é algo onipresente e ele se molda estando sempre à disposição dela. A internet é a eterna conexão.

O que preocupa Crary são questões que derivam diretamente deste comportamento conectado e moldado para ser um novo tipo de ser humano que não tem mais descanso e nunca desliga. Ele prevê um aniquilamento de singularidades como locais e acontecimentos, onde o único 'local' que se frequenta é a própria

\footnotetext{
${ }^{49}$ No Reino Unido a expressão usada é "around the clock" para aquele serviço que 'dá a volta no relógio', numa tradução literal.
} 
rede. E se este é apenas um efeito colateral de novas exigências institucionais, como ele coloca, a preocupação com o desenvolvimento humano se torna ainda maior quando há o que chama de "espoliação das tessituras complexas e das indeterminações da vida humana por 24/7 [quando] incita, simultaneamente uma identificação insustentável e autodestrutiva com suas exigências fantasmagóricas". (CRARY, 2014, p. 40) Não há, no entanto, uma eliminação das experiências externas, mas um empobrecimento das mesmas.

\subsection{Dócil}

A percepção de 'docilidade' do corpo e da mente do Usuário acontece quando se nota que ele não conhece outra realidade a não ser a de estar conectado. Talvez venha a ter até mesmo uma crítica em relação à própria rede e a forma como funciona, mas depende integralmente desta realidade comunicacional para estar inserido na sociedade. Ele está moldado para isso.

A título de suposição, talvez os Usuários do século 21 redescubram daqui a um tempo o contato físico, o olho no olho, que as relações pessoais que se dão quando uma pessoa encontra a outra fisicamente e não apenas virtualmente, e que há neste encontro uma experiência diversa da que acontece online. $\mathrm{E}$, quem sabe, isso tenha para alguns o sabor de revolução ou de uma criação tão sensacional cujo impacto se revele numa nova descoberta. Mas esse será, então, um outro ser humano com comportamentos que trazem uma bagagem reformulada a partir de parâmetros diversos dos atuais porque as relações dos Usuários estão em permanente reconstrução e recriação a partir de necessidades nunca antes experimentadas.

O Usuário é a primeira geração da espécie a ser totalmente conectada. Ou porque desconhece a vida de outra maneira, ou por opção, é dependente de um dispositivo eletrônico com acesso à Internet e de uma conexão em rede para estar inserido socialmente. Ele necessita de sistemas de admissão e controle que incluem ao mesmo tempo em que excluem e ao exigirem atenção permanente proporcionam o que Crary define como um "aniquilamento calculado da própria noite" (Idem, p. 42). Ele toma como base as experiências militares dos Estados Unidos com modelos de 
bombardeio, medo, opressão e um tipo soldado que nunca dorme entre as estratégias. Reforça a aspereza da solidão e da submissão ao abandono que a ideia de uma cultura $24 / 7$ denota. E destaca

\begin{abstract}
"a destruição do dia tanto quanto diz respeito à extinção da escuridão e da obscuridade. Por devastar toda a condição de luminosidade exceto as funcionais, 24/7 é parte de uma imensa incapacitação da experiência visual. Coincide com um campo onipresente de operações e expectativas ao qual estamos expostos e nos quais a atividade ótica individual é transformada em objeto de observação e administração. No interior desse campo, a contingência e a variabilidade do mundo visível não são mais acessíveis. As mudanças recentes mais importantes estão relacionadas não às formas mecanizadas de visualização, mas à desintegração da capacidade humana de ver, em especial da habilidade de associar identificação visual e avaliações éticas e sociais. Com um menu infinito e perpetuamente disponível de solicitações e atrações, 24/7 incapacita a visão por meio de processos de homogeneização, redundância e aceleração". (Idem, p. 43)
\end{abstract}

Diferentemente da ideia de que haverá uma unificação tecnológica e de que seremos todos capazes tecnologicamente, Crary tem uma visão mais sombria e, talvez, mais real. Acredita na transição constante com um consumo ininterrupto provocado por uma simulação contínua do novo e não nas manifestações definidoras das mídias. Um cenário de isolamento e de impotência política por jamais conseguir alcançar o sucesso. Porque a realização talvez seja estar sempre em busca do novo, nas Passagens onde todos se aglomeram no devir fantasmagórico do presente.

O presente 24/7 é constituído de "objetos individuais de competitividade, promoção, aquisição, segurança pessoal e conforto à custa dos outros. (Ibidem, p.50). No século 19 eram os projetos industriais que chamavam a atenção, no século 20 o consumo estava ligado às "fórmulas de regulação e obediência sociais" (Ibidem, p.51), enquanto que o Usuário hoje tem a novidade eterna como objetivo. Ele atua num continuum, um fluxo de atividades que lembra - em muito - o fluxo televisivo sobre o qual falava Williams ainda na década de 1970.

Para Williams, o fluxo era uma projeção de produções audiovisuais interligadas por outros produtos como intervalos comerciais e institucionais provocando uma sensação de que o espectador não via um produto específico, mas uma programação que estava à disposição de um Espectador passivo. A narrativa de fluxo mudou de um produto de comunicação específico para Programação. Na 
Internet passa de um acesso independente à rede em busca de visualizar algo específico, à um único e contínuo acesso como um estado do ser: estar acessado.

Dá-se uma reconfiguração do sujeito na sua própria troca de informações e mercadorias simbólicas na percepção de que não é a rede que foi necessariamente acessada pelo Usuário, mas este que foi acessado pela rede ao se conectar. E teve a existência transformada num estado de conexão permanente. É quando acontece a necessidade de suprimir o sono por causa da produção, do acesso e da visibilidade.

Para Agamben,

\footnotetext{
"hoje não haveria um só instante na vida dos indivíduos que não seja modelado, contaminado ou controlado por algum dispositivo. (...) É totalmente impossível que o sujeito do dispositivo o use 'de modo correto'. Aqueles que têm discursos similares são, de resto, o resultado do dispositivo midiático no qual estão aprisionados". (AGAMBEN, 2009, p. 48)
}

Para estar inserido no contexto social e cultural, o Usuário teve a vida transformada a um acesso constante a uma 'loja' de ofertas e demandas a começar pelo log-in e senha. Os ambientes são monitorados em diversas formas de controle e vigília. Neste ponto há duas variáveis para considerar: lembrando Foucault quando diz que não se trata necessariamente de uma teoria da conspiração, uma vez que o Usuário tem um acordo de acesso e utilização que foi 'assinado', mas percebe-se que existe uma forma de poder sendo exercida sobre o Usuário. E por outro lado é inevitável a constatação de que há um poder sendo exercido pelas instituições de comunicação: editorial, ideológico, de formação de opinião, por exemplo sobre qualquer Usuário.

Evidentemente que muitas vezes em nome do acesso, o Usuário aceita fornecer informações e prestar um serviço que não the agradaria em primeiro lugar, mas ao qual o fornecimento daquela informação está condicionado. É um contrato não só assinado física/virtualmente, mas uma assinatura afetiva de um acordo de necessidade e uso, de emprego da atenção, que parece ser mais profundo no sentido da dependência de um sujeito e o poder exercido sobre. Ele trata mais da ampliação e diversificação de fluxos do que propriamente um Big Brother que tudo vê e tudo sabe. Mesmo porque o estado de ser da Internet é de um Big Brother, portanto, este não é um assunto que sequer entra em discussão para quem usa, mas é aceito como condição sine qua non deste universo. 
Para refletir um pouco sobre este fluxo, é necessário pensar que Marx já enuncia a temporalidade $24 / 7$ quando fala que a fluidez do capital se expande para além das fronteiras físicas. A Internet é produto bem acabado do capitalismo contemporâneo que preza - como na sua origem - pela reorganização do tempo.

Numa vida agrária não havia uma necessidade de controle do tempo de produção. Com a fábrica moderna, a relação com a terra é constantemente empurrada para um apagamento, bem como as associações tradicionais de dependência, família ou comunidade. O capital se movimenta desconsiderando as fronteiras físicas nações, segue em busca do usuário/consumidor. O 24/7 é uma ideia de fluxo contínuo de informação alojando o Usuário numa temporalidade permanente com uma padronização das emoções e "aplainamento das subjetividades". (CRARY, 2014, pp.71-72)

Para impor um novo sistema hegemônico o capitalismo homogeneiza as formas de comportamento e desenvolve economias de trocas de informação com o sabor de grandes novidades, proporcionando novas Passagens e suas fantasmagorias para o aglomeramento dos Usuários no seu presente.

São os consumidores/Usuários que atuam num presente contínuo apagando os passados que geraram experiências, memórias e subjetividades e passam a pertencer a um fluxo eterno. As novidades tecnológicas são a dilatação, a acomodação e dependência das rotinas $24 / 7$. O que muda é a rotina ou o interesse pela novidade que ela oferece. A vida não muda, mas o controle dela, assim como os aspectos do descarte e da morte social ou digital.

Há um constante apagamento do passado para uma construção de um presente fantasmagórico através de uma ilusão da escolha dentro de um sistema global de autorregulação. Para Crary, reside aí um colapso das esferas de lazer e de trabalho, devido a uma obrigação de olhar imagens, dentro de uma ideia do que Foucault chamou de rede de observação permanente. E Crary revê o próprio conceito de Observador agora transformado em Usuário. Para ele o Observador é destituído do seu padrão de olhar e ocorre uma desestabilização 
de meios técnicos de transformar os próprios atos de visão em objetos de observação". (CRARY, 2014, p. 56)

A preocupação de Crary é a transformação da atenção em operações e respostas repetitivas que se sobrepõem ao ato de olhar e de escutar. $O$ olhar passa a se fixar num fluxo de informação e nas possíveis formas determinadas para entrega, exibição, formato, armazenamento, upgrades e acessórios das demandas estabelecidas pelo acesso à rede. Como a obrigação de olhar imagens é central para que instituições hegemônicas funcionem, a Internet se torna o maior meio de reprodução em massa de cultura. O Usuário é assim, o sujeito do visual, mais até do que do audiovisual, porque é o olhar dele que está condicionado a esta atenção $24 / 7$.

No tempo capitalista atual a atenção é mercantilizada no contato com as tecnologias do poder. As instituições como as fábricas, escolas, prisões, exércitos modernos, burocracias continuam a regular o comportamento. A Internet atua como uma versão aperfeiçoada delas. A rede mundial que prometia uma grande união dos povos através de um único meio de comunicação estabelece parâmetros de normatização do conhecimento com as novas tecnologias do poder. Deixa transparecer que os métodos não diferem muito de padrões capitalistas do século 20: promovem o apagamento dos antigos para estipular novos modos de ser e de ver. Não conhece fronteiras ou nações, compartilha com a sua origem um mesmo método de desalojar identidades e recriar um espaço-tempo voltado para o seu produto como centro das atenções. Remodela o corpo do sujeito comunicacional num "corpo sem fadiga" ${ }^{50}$ como era o sonho do século 19 e que hoje se mostra dócil e pronto para dedicar atenção e atender às demandas.

Crary percebe que no ambiente do Usuário o olho está desalojado do reino da ótica, porque mesmo com a padronização da sociedade de massa no século 20

\footnotetext{
50 "Atrás dos tratados científicos e filosóficos estava o sonho das classes médias do final o século XIX - um corpo sem fadiga" (RABINBACH, 1992, p. 44).

O ensaio de Carlos Herold Júnior sobre as "perspectivas no estudo da corporalidade e da educação no capitalismo contemporâneo" esclarece que a posição do corpo "nas rotinas produtivas perde a condição de ser um traço obviamente importante a partir da década de 30 do século XX, passando pelas décadas de 40,50 e 60 ofuscada pelo desenvolvimento das ciências cognitivas. Manovich (1993, s.p.) afirma que, nessas décadas, o movimento analítico daqueles que pensavam o trabalho pôs de lado o human motor (ou o corpo trabalhador), valorizando um novo 'instrumento': a mente. Jorda (1999) fala em 'homem-sistema' para pensar o perfil do trabalhador visto como elogiado nesse período". (HEROLD JÚNIOR, 2012, p.18)
} 
havia uma "distinção e separação" havia "espaços de tempo não regulados" (pp. 8586) e diz que numa sociedade de controle já não há mais brechas, espaços e tempos abertos. Dialoga com o que fala Deleuze que nas sociedades de controle os indivíduos tornam-se "dividuais", divisíveis, e "as massas tornaram-se amostras, dados, mercados ou 'bancos'”. (DELEUZE, 2008, p.222)

O Espectador do século 20 foi criado naquilo que pesquisadores chamam de "economia de atenção". São gerações que evoluíram a partir do contato com a tecnologia do Rádio, Cinema e Televisão e o Espectador foi moldado pelo audiovisual gerando um Usuário/Espectador otimizado e Ator/Produtor do próprio meio. A transição para o computador pessoal modifica o cenário do Espectador estável relativamente passivo, embora não há como desconsiderar a importância que teve o VHS e as possibilidades posteriores de gravar a programação da TV e o controle remoto para o passivo/dócil do computador como já vimos.

Surge, então, um Usuário com "muito mais recursos de mídia" - e ativo na rede de informações. O novo sistema é vendido como "democrático e antihierárquico", mas parece consistir numa nova maneira de atenção, mobilização e hábitos de rotinas que deixam de lado uma tecnologia e adotam a próxima. $O$ Usuário só tem que passar a perceber a Smart TV como uma central de entretenimento e não mais como somente um aparelho para emissão de produtos oriundos de uma emissora ou transmissora de TV. E saber utilizar os dispositivos móveis como tablets, Smartphones, assistentes virtuais, e qualquer outro que venha a substituí-los. Por exemplo: o Facebook Live que mostra que as redes sociais já se transformam em emissoras de televisão. A TV foi a forma mais eficiente de acessar os produtos audiovisuais até a disseminação da Internet doméstica. Na medida em que se percebe a televisão como um meio de emissão de produtos audiovisuais e uma forma popular de grande alcance para divulgação material pré-produzido com uma curadoria específica e decisões que atendem a determinados pressupostos de empresas de mídia. Quando o Usuário passa a produzir material com o uso de ferramentas e dispositivos tecnológicos, ele está envolvido e passa ser, em si, o próprio ato de comunicação ao vivo. Como no Metáporo da comunicação durante, uma transmissão desta natureza pode publicizar qualquer tipo de conteúdo.

Após alguns aplicativos funcionarem como ferramentas de transmissão ao vivo independentes de redes sociais, este dispositivo de transmissão ganha ainda 
mais corpo, presença e visibilidade quando está vinculado a uma rede como o Facebook Live ${ }^{51} \mathrm{com}$ a possibilidade de transmitir vídeo ao vivo em alta definição. $\mathrm{O}$ que significa que as redes sociais podem entrar pelo Facebook e transmitir qualquer tipo de produto audiovisual ao vivo como shows, palestras, aulas, manifestações públicas para um público potencial de mais de dois bilhões de pessoas. Uma audiência bem razoável se considerarmos todo o material pode ser compartilhado e visualizado infinitamente a partir do momento da transmissão. Um público disputado pelas emissoras de TV.

Há que se ponderar que no caso do Facebook Live trata-se de uma rede social e de um acesso mundial, mas há poucos números de TV que podem ser comparados com as redes sociais na Internet e que, mesmo grandes números, quando comparados, são inferiores em termos de alcance e no que pode estar implicado em termos de monetização de marcas e empresas.

Um dos grandes atrativos das ferramentas de live boradcast é aquilo de que carecem as emissoras de TV: a participação. E esta participação acontece a partir também de uma certa liberdade de manifestação, embora com imposições sobre o conteúdo publicado pelos detentores das redes, mas mesmo assim com muito mais liberdade do que o publicador do conteúdo teria ao participar de alguma colaboração num produto de uma emissora de TV.

Há infinitas possibilidades para uma ferramenta como o Facebook Live. Se as redes de TV já utilizam o próprio Facebook para promover os produtos audiovisuais das emissoras, o Live parece fornecer outras possibilidades de promoção e publicização em relação à própria TV ao vivo, como os bastidores dos programas, material exclusivo publicado ao vivo, atraindo público para o evento em si que será transmitido e para o site do produto, criando um ciclo infinito de acessos e conexões, curtidas, postagens, retornos e, no fim da linha, visibilidade para os anunciantes, que associam o seu produto àquele produto audiovisual/emissora/rede/empresa e princípios ideológicos conectados me rede.

Neste contexto, uma ferramenta como esta fornece uma imensa quantidade de informação sobre o público: quem são, o que mais assistem - e o que assistem por inteiro e o que abandonam depois de alguns minutos - que marcas preferem, onde moram, para onde viajam, quem são seus amigos, e tudo isso a respeito deles

\footnotetext{
${ }^{51}$ Disponível em: https://live.fb.com/. Último acesso em 22 de março de 2018.
} 
também. E ainda: o Facebook terá todas essas informações num nível individual e não da família. Este tipo de informação é importante para as redes sociais por inúmeras finalidades como, por exemplo, construção e retenção da audiência quando as redes de comunicação focam em usuários para aumentar o público para determinados tipos de produtos como noticiosos ou reforçam os laços já existentes com o público; decisões de programação - as redes de comunicação podem usar as informações para tomar decisões de alto nível em relação a programação tais como decidir a aquisição de conteúdo; estratégias publicitárias - anunciantes podem atingir segmentos de públicos específicos com a publicidade, enquanto as mesmas informações podem ajudar a construir estatísticas para produtos já existentes.

A pergunta agora é o que o Facebook vai fazer depois das transmissões ao vivo? Uma questão para ser respondida com o tempo e a experiência, que não deve demorar nada a aparecer. Talvez o Facebook trabalhe com o sistema e não contra ele, permitindo que os usuários utilizem as credencias da rede social para autenticar assinaturas já existentes de TV paga. Não há limite. Esta adaptação à ferramentas integra um sistema que conduz o Usuário a desfrutar de serviços renovados numa miríade interminável de novidades com a finalidade de atrair o público para o que pode ser percebido como as Passagens na fantasmagoria contemporânea, um deslocamento do homem do centro para o local de atenção dedicada às respostas que devem ser dadas aos dispositivos. A máquina passa a ser o centro e o Usuário uma ferramenta dela.

Um Usuário é obrigatório para a existência da máquina que depende de participação e da produção de um volume necessário de informação para existir. No entanto, há uma inversão de valores entre Usuário e objeto usado. É possível detectar um contrassenso quando se percebe que o Usuário é necessário para a máquina existir e a individualidade dele ainda mais importante para os algoritmos produzirem informação para a continuidade do produto ou do dispositivo. Porém, ele não é tratado como aquele indivíduo específico, mas "um indivíduo qualquer", um "acesso" e, assim, deslocado de sua subjetividade. Mesmo com o risco de uma conclusão prematura, percebe-se que não importa a relevância da visibilidade, do número de seguidores e financeira que um vlogueiro tenha para uma rede como o Youtube, por exemplo. Ele pode ser facilmente substituído pela próxima novidade. São identidades substituíveis como nos fala Crary. 
O Usuário vive um estado de necessidade de pertencimento aliado a um estado de solidão eterna. Do seu lugar de manifestação, seja como ator/espectador ou como ator que interfere ou produz conteúdo, ele é sozinho porque seus atos são buscas de possibilidades e uma ilusão do encontro de Debord num cenário de espetáculo midiático:

\begin{abstract}
"O que a ideologia já era, a sociedade acabou sendo. A desinserção da práxis e a falsa consciência antidialética que a acompanha, eis o que é imposto a cada hora da vida cotidiana submetida ao espetáculo; que deve ser compreendido como uma organização sistemática do 'desfalecimento da faculdade de encontro' que é substituído por um fato alucinatório social: a falsa consciência do encontro, a 'ilusão do encontro'. Numa sociedade em que ninguém pode mais ser reconhecido pelos outros, cada indivíduo tornase incapaz de reconhecer sua própria realidade. A ideologia está em casa; a separação construiu o seu mundo". (DEBORD, 2003, P.163)
\end{abstract}

Para evitar a separação, as redes devem trabalhar a serviço de relações já existentes. Porque, do contrário, se forem formadas com base nas "experiências e proximidades compartilhadas, apenas reproduzirão e reforçarão a segregação, a opacidade, as dissimulações e o interesse próprio inerentes ao seu uso". (CRARY, 2014, p. 130)

Em busca de uma reflexão que conduza a lugares menos colonizadores da sensibilidade há que se traçar por caminhos que permitam reconceber experiências individuais e que tratem de uma reificação do indivíduo, agora um sujeito que "cria concepção de si, que otimiza ou viabiliza participação em ambientes e velocidades digitais". (Idem, p. 109)

Desenha-se a questão de como permanecer humano diante de um mundo deslocador. A contemporaneidade não pressupõe subjetividades. A menos que sejam subjetividades. A coleta de dados permanente transforma a privacidade em algo impossível e os sujeitos em vigilância eterna. "Acumulamos um mosaico de identidades substituíveis que subsistem 24/7, sem dormir, continuamente como personificações inanimadas mais do que como extensões do eu" (p.114) afirma ele, que define "inanimado" neste contexto menos como ausência de movimentos e mais como "liberação simulada dos estorvos de estar ao vivo que são incompatíveis com a circulação e com a troca". (Idem, p.114) E finaliza dizendo que empobrecemos sensorialmente, e que a redução da percepção, do hábito e as respostas 
programadas "são resultados inevitáveis de nosso alinhamento aos inúmeros produtos, serviços e 'amigos' que consumimos, administramos e acumulamos durante a vigília". (Ibidem, p.114)

Diante do contexto de trabalho eterno, duas formas de poder estriam em jogo: "o político, que se despedaça, e o poder neurológico técnico cognitivo e neural [neural power], que cresce de maneira cada vez mais intensa, onipresente e inevitável" (BERARDI) ${ }^{52}$.

O debate que ele propõe atualmente é o de emancipação do conceito de salário com forma de desenredar a trama do poder que aponta uma possibilidade de enxergar o sujeito como indivíduo. Em seu comentário recorre à Foucault dizendo que escreveu sobre a "inabilidade da mente moderna de ter a possibilidade de ver a emancipação do salário". Trata como superstição a ideia de que é impossível se livrar do salário e de que a vida se torna precária e impotente sem o salário e sem o trabalho. Há na visão de Berardi uma dominação neurológica em busca de um cérebro global, uma forma de "neurototalitarismo". E diz que conseguir desarmar esse processo é o grande problema político e filosófico que enfrentamos no momento.

A partir de Crary e Berardi torna-se viável a reflexão sobre o apagamento da ideia do outro, de si mesmo e de como a cultura na internet traz ao Usuário uma preocupação com o local de onde ele fala. No entanto, isto implica em trazê-lo para uma globalidade que pode não representá-lo de maneira real e de um lugar de cultura que deixa dúvidas sobre 1) se ele se tornou invisível; 2) se ele se tornou cultural na medida da necessidade do meio utilizado, ou ainda 3) se o local da cultura passa a ser o local onde o próprio Usuário está e de onde fala. Não se trata de um local necessariamente físico, mas de uma fantasmagoria do presente. As duas primeiras possibilidades parecem contidas nesta última e integram uma narrativa comum, o que deixa o local onde o Usuário está como a noção da própria Passagem que atende na contemporaneidade pelo nome de rede social.

Uma experiência feita em sala de aula no início dos 2000 nos Estados Unidos, dava conta de uma professora que pediu aos alunos que não utilizassem nenhum dispositivo eletrônico durante 24 horas. ${ }^{53}$ No primeiro momento, os alunos

\footnotetext{
52 Palestra I.C.A - Londres - tradução desta autora.

${ }^{53}$ Caso narrado no livro Amusing Ouserselves to Death, de Neil Postman. p. xii.
} 
não pareceram se importar muito, considerando que seria fácil. Mas quando se deram conta de que deveriam abrir mão de celular, computador, Internet, TV, rádio, etc., começaram a ficar preocupados. Pelas regras, eles poderiam ler livros, mas se atendessem o telefone, ou verificassem o e-mail, teriam que começar tudo de novo. Os textos dos alunos a respeito do exercício tinham títulos sempre extremos como "O pior dia da minha vida", ou "A melhor experiência que eu já tive" e "Eu achei que ia morrer". O telefone ou a internet era apenas os meios, mas cada um deles teve que lutar contra um hábito mais profundo: a própria ansiedade de responder a uma demanda de um dispositivo tecnológico que estabeleciam uma relação humana. No entanto, o fato de ter permanecido em abstinência, mesmo odiando a ideia, fez com que eles fizessem coisas que há muito tempo não faziam: caminhar na rua para visitar um amigo, conversar, interagir com outro ser humano ao vivo. Alguns alunos mudaram e decidiram espontaneamente tornar o exercício uma prática pessoal periódica. Deve ser levado em conta que à época da experiência, a vida cotidiana não era tão dependente da Internet como é hoje, as redes sociais estavam dando os primeiros passos com o Orkut e os relacionamentos ainda desfrutavam de um maior hibridismo entre o virtual e o real.

Ao citar esta experiência não há neste texto nenhuma invalidação das relações estabelecidas online, de como estas vivências acontecem ou qualquer julgamento neste sentido, mas uma visão das relações de dependência que criamos com os dispositivos e com a tecnologia. Atualmente já se pode contar com projetos de desintoxicação para dependentes de tecnologia com profissionais da área da saúde, comunicação e educação que pesquisam sobre como as tecnologias podem interferir no comportamento humano e oferecem "suporte e tratamento aos usuários abusivos de tecnologia". 54

A abstinência proposta pela professora em sala de aula e o comportamento considerado como "um vício" em tecnologia têm um relacionamento direto com a ideia central de Crary na teoria 24/7. O sono para ele hoje é a única fronteira disponível para se contrapor ao capitalismo que tudo transforma em mercadoria e tem na atenção um de seus bens mais valiosos. O texto discorre sobre as formas de

54 Disponível em:

http://www.spacedaily.com/reports/Brazils_tech_junkies_seek_healing_at_digital_detox_clinic_999.ht $\mathrm{ml}$

http://www.institutodelete.com/quemsomos

Último acesso em 23 de março de 2018. 
como o corpo do Usuário foi sendo moldado/docilizado para atender a realidade tecnológica que vivemos e a maneira como se dá a colonização da sensibilidade.

O sono de Crary é uma das únicas experiências contemporâneas na qual estamos sob o cuidado de outros e numa relação mútua de apoio e de confiança, mas também num momento de "liberação periódica da individuação - um desemaranhar noturno da trama frouxa das subjetividades rasas que habitamos e administramos durante o dia". (CRARY, 2014, p. 134) Torna-se, assim, uma liberação do que ele chama de "permanente continuidade", um "retiro da nulidade e esterilidade calamitosa da práxis 24/7", (Idem, p. 135) e um momento em que recuperamos sensibilidade e atenção. Ele acredita que a ausência daquele que dorme contém uma "ligação com o futuro, como uma possibilidade de renovação e, assim, de liberdade". Pondera que no século 21 , a perturbação do sono

\begin{abstract}
"possui uma relação mais problemática com o futuro. Localizado em algum lugar na fronteira entre o social e o natural, o sono garante no mundo a presença dos padrões sazonais e cíclicos essenciais à vida e incompatíveis com o capitalismo. (...) Nesse contexto, a inércia restauradora do sono se coloca contra a letalidade de toda a acumulação, a financeirização e o desperdício que devastam tudo aquilo que se costumava chamar de domínio comum." (Idem, p. 136)
\end{abstract}

Mesmo que pareçam antagônicos numa primeira visada, o sono de Crary e o "despertar" sugerido na "permanente luz diurna" de Nietzche em que se torna necessário acordar para agir, num contexto do homem heroico, que só assim pode desafiar as convenções e fazer a revolução, compartilham da mesma premissa: um chamado para a ação. Se então era o acordar, o heroísmo de Crary está em desligar, dormir, se desconectar. O próprio Crary vive o que defende. Professor na Universidade de Columbia, em Nova York, não possui telefone celular, prefere uma vida sem tantas conexões e diz que preza mais a qualidade das amizades e a conexão com pessoas. "Talvez haja alguns déficits por causa disso. Mas eu sou mais feliz sem tudo isso", diz ele. ${ }^{55}$

$\mathrm{Na}$ conversa, Crary se mostrou cético em relação à crítica feita sobre as mídias sociais. Para ele, há muitas pessoas cujo futuro está completamente baseado no pressuposto de que a Apple, Facebook, Google, Ali Baba, todos as

\footnotetext{
${ }^{55}$ Conversa entre esta pesquisadora e Jonathan Crary em 27/09/2017 na Universidade de Columbia, Nova York, EUA.
} 
grandes empresas de tecnologia, vão não apenas persistir mas florescer ao mesmo tempo em que esses críticos querem imaginar uma mudança social significativa. Em outras palavras diz que "todos falam em um mundo mais igualitário. Eles estão completamente cegos sobre esta contradição, especialmente quando falam sobre uma política que é baseada na Internet. Eles falam sobre uma política que é baseada na sobrevivência dessas mesmas empresas". Completa dizendo que mesmo que as empresas preguem, elas não fazem negócios de maneiras igualitárias, que há uma má fé entre alguns críticos que veem as mídias sociais como parte de uma solução política. "E eu sou cético sobre isso, cético e pessimista. As subjetividades que estão sendo criadas e geradas. Tudo isso requer uma nova noção do que a subjetividade é em comparação com o que se vê nas técnicas do observador? Eu mesmo não tenho a resposta. É uma combinação mais híbrida das identidades históricas que ficaram (leftover historical identities) e as coisas que nós nem mesmo conseguimos enxergar perfeitamente nesse ponto".

Pergunto sobre o processo de mudança do olhar século 19 ao 21 como um processo de desenvolvimento tecnológico que se tornou na ideia do 24/7. Em termos de desenvolvimento humano, o que muda na percepção no modo como lidamos com a informação. Como no século 19 antes da tecnologia da visão. Ele pensa cada vez mais que não é somente capitalismo, mas é a civilização, se é que podemos separar esses dois. Neste momento volta as atenções para uma reflexão sobre o capitalismo e as necessidades nascidas a partir dos limites do do crescimento econômico, a produção de extração [extraction production] e as formas de subsistência das quais dependeremos ou esgotaremos em breve. Afirma que muito da modernidade, da civilização moderna urbana, está baseada em quase um tipo de desprezo pela subsistência em oposição ao crescimento.

Para Crary muitas das estratégias políticas para o presente dependem da persistência de um modelo completamente impraticável. "Penso como no século 19 como a marginalização de um mundo agrário era tão crucial para as imagens de uma 'maternidade libertadora'. Todos os grandes movimentos do século 20 eram sobre a celebração de um mundo construído, da vida de um universo que era completamente estranho ao mundo dos animais e das plantas. Há muita gente que eu conheço - e conheço bem - que não consegue abandonar aquelas imagens. Haverá soluções tecnológicas e nós podemos transformar as nossas cidades em 
locais bons pra se viver". Na opinião dele, as únicas opções políticas para o futuro são as de se reconectar com as maneiras e formas de auto-suficiência. A ideia de uma comunidade global é baseada na circulação global de bens e quando os debates são sobre o local versus o global "eu sempre fui cético sobre a celebração do global. Acho que essa ideia sempre está mais a serviço das necessidades das corporações do que os indivíduos".

Entre vários outros assuntos tratados, Crary termina a conversa dizendo que "muito da modernidade, da civilização moderna urbana está baseada em quase um tipo de desprezo pela subsistência em oposição ao crescimento". Preocupado com a dependência do capitalismo global, sobre comunidades em rede e indivíduos em rede. Ele escreve atualmente sobre como o planeta não será sustentável indefinidamente. "Nós podemos postular um futuro que pressupõe que o capitalismo global vai continuar a florescer e a gerar receita e continuará a introduzir novos serviços de consumo, produtos e aplicativos num ritmo crescente. É onde estamos agora e essa é uma situação insustentável". Ainda fez um último comentário generosamente corroborando esta pesquisa: "acho que da maneira como você está pensando há muita verdade nisso. Não me parece que você esteja tirando conclusões políticas. Está fazendo um tipo de diagnóstico e um tipo de anatomia valiosa sobre este sistema. $\mathrm{E}$ ao final talvez pudesse tirar algumas conclusões sobre se estas ideias são historicamente sustentáveis". 
Capítulo 6

DESDOBRAMENTOS POSSÍVEIS 


\section{Desdobramentos possíveis}

Este trabalho lida com o efêmero da transformação constante da sociedade num tempo de mudanças rápidas que requer reflexões. E a intenção é a de colaborar com teorias e associações que possam fomentar o debate e traçar um panorama, ou um diagnóstico da evolução de um tipo de sujeito comunicacional contemporâneo que existe neste presente comunicacional. O Usuário é ao vivo e efêmero como as lives do Facebook como as Stories do Instagram ${ }^{56}$.

Como um Sujeito Múltiplo o Observador/Espectador/Usuário concentra peculiaridades de cada um dos três sujeitos e transporta ao longo do percurso temporal-tecnológico a sua bagagem cultural:

1) Como Observador, ele teve o olhar transformado durante o século 19 e na virada para o $20 \mathrm{com}$ mudanças na arquitetura que trouxeram as Passagens, e uma nova forma de convívio. A busca pela novidade atraiu a população para o consumo e uma maneira de estar na cidade diferente do que se tinha até então.

O uso do espaço público foi modificado e o Observador/Flanêur encontrou na cidade o local do olhar, da crítica e do ser. Acompanhado pelas transformações tecnológicas dos dispositivos pré-cinematográficos e fotográficos, ele reconfigurou 0 olhar e o sujeito foi ressignificado. Trouxe consigo uma noção de lugar e de local público que influenciou a maneira de ser de um modo definitivo. Inicia-se aí um caminho que trata da evolução/transformação do sujeito ainda contemplativo/passivo exposto à atos comunicacionais que podem ser visualizados como passíveis de crítica. A reflexão se inicia com o próprio Flanêur na cidade: um sujeito em movimento que busca entender o seu local social e cultural.

2) O contato intenso com o espetáculo nunca desassociado da tecnologia faz do Espectador um sujeito midiático passivo e que foi marcado pelas transformações ao longo do século 20. Ele desfrutou de todas as possibilidades e começou a pavimentar um caminho de atuação nas mídias.

\footnotetext{
${ }^{56}$ Recurso de postagens de fotos que que se interconectam contando uma breve estória e que desaparecem da rede social depois de 24 horas.

Disponível em: http://www1.folha.uol.com.br/mercado/2017/10/1931057-com-50-milhoes-de-usuariosbrasil-e-segundo-no-ranking-do-instagram.shtml

Último acesso em: 23 de março de 2018.
} 
O contato diário com o audiovisual que se tornou pouco a pouco permanente, construiu mais uma etapa na configuração do olhar, ressignificando o sujeito que buscou interferir e/ou interagir na produção de informação, declarando preferências e conseguindo optar pelo tipo de produção que queria estar em contato. Outro aspecto e que diz respeito ao contato com a Televisão, foi a ação de remontar as opções de programação a partir de um maior controle sobre os produtos que o afetavam. Como Espectador, ele já demonstrava a construção de um perfil estabelecendo preferências e determinando direcionamentos sobre os produtos com os quais desejava ter uma experiência.

3) O Usuário chega ao novo milênio com uma postura de atuação. Como um novo crítico, ele utiliza a informação que Ihe é dada, mas também impõe preferências através do perfil estabelecido nos acessos à Internet. As facilidades e o estímulo do contato tecnológico o auxiliam a também produzir informação e, assim, manter uma conexão sempre mais intensa com a tecnologia.

É um passivo/ativo que se faz visível numa união de necessidades e possibilidades. A existência está condicionada à visibilidade e à ação que fará com que este novo sujeito descortine modos de ser e de estar para si próprio e para os ambientes que frequenta.

Quando se percebe o Usuário a partir dos pontos de vista e pressupostos colocados ao logo deste texto, observa-se que ele tem algo de um Flanêur do século 21, quando se utiliza de uma mobilidade físico-tecnológica através do uso dos dispositivos móveis. Ele está na cidade/ambiente e atua todo o tempo como um crítico. Movimenta-se, demonstra localizações traçando mapas referenciais e políticos. Portanto, o sujeito deste trabalho não significa um igual, mas o múltiplo, o híbrido, um diverso que permeia e é permeado pelas várias narrativas que se desenrolam a partir do contato com a tecnologia que incorpora e se deixa incorporar pela contemporaneidade; deseja estar nela e traz consigo esta carga cultural/tecnológica adquirida.

Ele se posiciona como sujeito numa mesma frequência do Flanêur à medida que lida com a novidade, o agrupamento - antes, nas Passagens e agora nas redes sociais - com o experimento do novo que lhe é imposto todos os dias e que o Usuário aprende e utiliza e reaprende e reutiliza: uma rotina conhecida na prática cotidiana contemporânea. 
O Usuário é atuante. Ele tem a perspectiva do sistema que o mantem e o incorpora. Mas, ao mesmo tempo, reage e debate tudo isso em busca de um processo de passagem e de sentido. O Usuário é um ser social e uma forma de estar em sociedade que tem na transitoriedade uma característica do que se pode chamar de 'existência Usuário/Flanêur'.

\subsection{A colonização da sensibilidade e a mercantilização da atenção}

O Flanêur trouxe até aqui o Observador, o Espectador e o Usuário. Todos conectados por estímulos semelhantes em épocas distintas. Estes sujeitos que ao final se apresentam como um só, uma transformação/evolução de um no outro se desenvolvem ao contato com a tecnologia, o motor da história e unidos em todos momentos por uma mercadoria preciosa: a atenção.

Já se falou da atenção nesta pesquisa e da colonização da sensibilidade. No entanto, nestas considerações finais é importante que se fale de porque está ligada à figura do Usuário que é o sujeito da comunicação contemporânea.

Um breve parênteses: a pesquisa agregou dois autores que chegaram ao conhecimento da autora tardiamente no processo de confecção do texto final. São: Tim Wu e Byung-Chul Han. O primeiro tratando essencialmente da mercantilização da atenção e o segundo sobre os extremos da atenção e da exaustão vividos atualmente. Ambos foram incluídos aqui por dialogarem de maneira muito próxima com os textos lidos e discutidos anteriormente e por trazerem uma contribuição de atualização ao sujeito comunicacional em discussão.

Alguém poderia perguntar: atenção a quê? Porque isso tem importância? Utiliza-se a resposta de Wu quando diz: "Simplesmente porque esta indústria [da informação, neste caso], cujo negócio principal é a influência da consciência, pode radicalmente moldar como nossas vidas são vividas". (WU, 2017, p. 6)

A Internet exige atenção e ação, e se esta ação for tão somente acessar uma página, rede social, ou site, já é suficiente para que a atenção tenha sido capturada e provavelmente seja utilizada para finalidades já mencionadas, como o desenvolvimento de produtos e serviços; consumo de mercadorias; a monetização de empresas e a visualização de material na rede. 
Gerações anteriores poderiam sentir sua privacidade invadida pela televisão que retirava as pessoas do convívio para assistir as poucas horas diárias de programação que a TV exibia no início. Depois aprenderam a conviver assistindo TV. Posteriormente, cada um no seu cômodo da casa com a sua própria TV. Assim a atenção foi sendo colonizada e, da mesma forma, acontece com a sensibilidade. Há que se pensar que a indústria já percebia o potencial em chamar a atenção dos consumidores com suas vitrines nas lojas das Passagens da Paris do final do século 19, por onde circulava o Flanêur.

Wu lembra que gerações bem mais recentes

\begin{abstract}
"achavam impressionante que sem remuneração ou muitos protestos nossas redes de contatos familiares, de amizades e conhecidos tenham sido recrutados pelas mídias sociais para ajudar a vender coisas para nós". $(\text { Idem })^{57}$
\end{abstract}

E continua dizendo que atualmente "a maioria de nós carrega dispositivos nos corpos, que o tempo todo encontram maneiras de comercializar as menores partículas do nosso tempo e nossa atenção" (Ibidem). Basicamente tudo o que puder ser vendido, capturando atenção em troca de um conteúdo 'gratuito'.

Os hábitos mudam e certamente essa dependência da rede irá se transformar em algo como 'menos dependência'. Mas a rede certamente não vai desistir dos Usuários e vai encontrar uma maneira de penetrar ainda mais no seu cotidiano, rotina, privacidade, sem que precise necessariamente estar direcionando atenção para o dispositivo todo o tempo. Inverte-se o jogo, mas não o ganhador: a Internet usa os movimentos do Usuário para fazê-lo consumir. Com a Internet das Coisas ${ }^{58}$ o refrigerador está ligado em rede, bem como o fogão. O refrigerador saberá se o Usuário prefere maçãs ou abóboras; o fogão entenderá qual receita é executada com mais frequência. O relógio de pulso ou o celular rastreiam e mostram o histórico do percurso que o Usuário fez até o local de trabalho e detectam detalhes dos

\footnotetext{
${ }^{57}$ A tradução dos textos de Tim Wu foram feitas por esta autora.

${ }^{58}$ Num sentido mais amplo, a expressão Internet das Coisas (IoT em ingles para Internet of Things) agrupa qualquer coisa que esteja conectada pela Internet, mas passou a ser utilizada para definir objetos conectados que se comunicam uns com os outros, podem ser 'usáveis' como um relógio ou um GPS e captam informações a respeito de seus usuários, analisam estas informações e criam ações para auxiliar com uma tarefa específica, ou aprender a partir de um processo.

Disponível em:

http://www.wired.co.uk/article/internet-of-things-what-is-explained-iot Último acesso em 23 de março de 2018.
} 
movimentos dele. E as várias telas passarão a oferecer produtos ligados a estas ações e situações com anunciantes ligados a eles.

A Internet já dá atenção ao Usuário cuidadosamente registrando cada passo e se informando respeito. Haverá, sim, um grande irmão, amigo, companheiro. Não será mais necessário uma pessoa real ao lado porque as telas mostrarão várias que o conhecem como ninguém. Sabem da intimidade sem que o sujeito tenha que pronunciar uma palavra. Estará sozinho e muito acompanhado.

A personalização de conteúdos é uma realidade. Pesquisas realizadas no Massachussets Institute of Technology (MIT), nos Estados Unidos exploram as tecnologias de inteligência emocional e desenvolvem possíveis dispositivos que sejam capazes de compreender melhor os usuários e torne a comunicação com as máquinas mais personalizada. Um telefone celular pode, por exemplo, saber se o usuário está passando por um mal momento, filtrar as notícias e deixar as mais negativas em segundo plano. Pode inclusive "sugerir uma música ou conversar com algum amigo que ele saiba que está nas proximidades para melhorar o ânimo de seu usuário". 59

A depender da realidade de cada um, este pode ser um contexto real ou nem tão distante do presente assim, onde o sujeito talvez não saberá mais se ele presta atenção por escolha ou por que está programado para isso, porque não tem escolha a não ser prestar atenção. "É o risco de viver. As nossas vidas passaram a ser menos nossas do que imaginamos". (Ibidem, p.7)

Há sempre a opção de ignorar, desligar ou desconectar. Embora o individualismo seja uma característica dos dias atuais, o Usuário está sempre pertencendo a grupos na rede, o que torna mais difícil o ato subjetivo de se desconectar. Crary, como foi visto, defende o sono em nome da subjetividade e da autonomia. Wu fala da mercantilização da atenção e Berardi da colonização da sensibilidade. Formas de criticar o sistema e os novos modelos de vida levadas ao extremo da atenção, reação e exaustão.

O tempo da reflexão se tornou outro. Um tempo quase sem tempo. A reflexão - quando há - acontece simultaneamente à ação porque não há intervalos. Neste contexto, existe uma demanda dos fluxos de trabalho contemporâneos, cuja

\footnotetext{
59 Disponível em:

https://retina.elpais.com/retina/2017/11/27/innovacion/1511787603 364241.html Último acesso em 23 de março de 2018.
} 
população jovem e produtiva integra uma sociedade prematuramente exausta por suas próprias demandas e do que Han chama de sociedade do cansaço.

Ele alerta que o Usuário vive numa sociedade de excesso de positividade, de estímulos, informações e impulsos, o que

\footnotetext{
"modifica radicalmente a estrutura e economia da atenção. Com isso se fragmenta e destrói a atenção. Também a crescente sobrecarga de trabalho torna necessária uma técnica específica relacionada ao tempo e a atenção, que tem efeitos novamente na estrutura da atenção". (HAN, 2015, p. 31)
}

E coloca a multitarefa como um retrocesso que tornaria a atenção mais rasa e selvagem. A hiperatividade é fazer o eterno sem pausas, sem liberdade para o 'não fazer' e, consequentemente, para o pensar, refletir, existir para além da atividade, expondo assim o 'risco' de pensar a respeito dela: "a hiperatividade é paradoxalmente uma forma extremamente passiva de fazer, que não admite mais nenhuma ação livre. Radica-se numa absolutização unilateral da potência positiva". (Ibidem, p. 58)

Uma positividade excessiva é um elemento tornado 'status quo' na sociedade em rede e gera, para Han, uma demanda saturante que causaria depressão e esgotamento, uma vez que a violência da positividade não é privativa e porque "não é o imperativo de obedecer apenas a si mesmo, mas a pressão de desempenho". (Ibidem, p. 27) Por isso estabelece inclusive uma breve crítica ao que chama de "negatividade" da sociedade disciplinar de Foucault porque considera não abarca a mudança da sociedade contemporânea ao não se vincular à negatividade mas a uma positividade brutal e opressora.

A busca pela atenção do Usuário é mais profunda e possui um grau de detalhamento que não havia no século 20 do Espectador ou no 19 do Observador. Mas como estes sujeitos são uma transformação de um no outro, a busca pela atenção do sujeito comunicacional também evoluiu para o que se vive hoje. Os estímulos aos quais cada um é submetido são muito semelhantes, guardadas as devidas proporções de temporalidade. Para Shirky, as lógicas anteriores como a lógica televisiva,

"tratavam os espectadores como pouco mais do que coleções de indivíduos. Seus membros não agregavam qualquer valor real uns aos outros. A lógica da mídia digital, por outro lado, permite que 'pessoas antes 
conhecidas como espectadores' agreguem valor umas às outras todos os dias". (SHIRKY, 2010, p. 41)

$\mathrm{Na}$ visão dele são ferramentas de comunicação em novas mãos e que assumem novas características. Um valor precioso para a produção de informação, produtos e serviços, que colocam o Usuário como um sujeito dessubjetivado no ato comunicacional mas com a aparência de um sujeito subjetivado. A subjetivação parece ser traçada à medida que ele se insere no sistema em mesmo que crítico, tem a sensação de ter autonomia o tempo todo. Há que se reforçar que o Usuário é crítico do momento em que vive, estabelece sua existência no transitório e no efêmero da comunicação em rede e que sua existência como Usuário se dá quando dentro deste sistema.

Crary sonha com um mundo

"compartilhado cujo destino não é terminal, um mundo sem bilionários que não tem a barbárie do pós humano e, no qual a história pode assumir outras formas além dos pesadelos reificados da catástrofe. (...) Seriam insinuações do sonho como interrupção radical, como recusa do peso impiedoso do nosso presente global, do sono que, no nível mais mundano da experiência cotidiana, pode sempre esboçar contorno de renovações e começos mais plenos de consequências". (CRARY, 2014, p. 137)

Berardi questiona se seremos capazes de fazer a desconexão de um mundo tecnológico-financeiro-autômato e partir para uma evolução neurológica.

\footnotetext{
"Os seres humanos serão capazes de encontrar uma nova linguagem conjuntiva no mundo conectado dos códigos digitais? Será que o prazer, o afeto e a empatia encontrarão maneiras de reemergir fora de um ordenamento conjuntivo?" (BERARDI, 2015, p. 338)
}

Embora nem todas as visões sobre a Internet e a vida em rede compartilhadas nesta pesquisa sejam otimistas, são, no entanto, questionadoras e críticas da contemporaneidade. Acredita-se que há maneiras de construir realidades com mais autonomia, subjetividades e liberdade e que os Usuários - que somos todos nós - possam "individual e coletivamente, fazer a nossa atenção ser nossa de novo e, então, reivindicar a posse de cada experiência da vida". (WU, 2017, p. 353) 
BIBLIOGRAFIA 


\section{Bilbiografia}

ADORNO, Theodor W. HORKHEIMER, Max. Dialética do esclarecimento. Rio de Janeiro: Jorge Zahar Editor, 1985.

ADORNO, Theodor W. Industria cultural e sociedade. Rio de Janeiro: Paz e Terra, 2006 .

AGAMBEN, Giorgio. O que é contemporâneo e outros ensaios. Chapecó: Argos, 2009.

ANDERSON, Benedict. Comunidades imaginadas, reflexões sobre a origem e a difusão do nacionalismo. São Paulo: Companhia das Letras, 2008.

APKON, Stephen. The age of the image: redefining literacy in a world of screens. Nova York, Estados Unidos, Farrar, Straus and Giroux, 2013.

ARBEX JR., José. Showrnalismo: a notícia como espetáculo. São Paulo: Casa Amarela, 2001.

ARENDT, Hannah. A Condição Humana. Rio de Janeiro: Forense Universitária, 2010.

BARBERO, Jesús Martin et REY, Germán. Os Exercícios do ver. São Paulo: Editora SENAC, 1999.

BARTHES, Roland. O óbvio e o obtuso. Editora Nova Fronteira. Rio de Janeiro: 1982.

BAUMAN, Zygmunt. ModernidadelLíquida. Rio de Janeiro: Jorge Zahar Editora, 2001.

Retrotopia, Rio de Janeiro: Jorge Zahar Editora, 2017.

BENJAMIN, Walter. Obras Escolhidas, v. I, Magia e técnica, arte e política, trad. S.P. Rouanet, São Paulo: Brasiliense, 1985.

. Obras Escolhidas, v. II, Rua de mão única, trad. de R.R. Torres F. e J.C.M. Barbosa, São Paulo: Brasiliense, 1987.

Obras Escolhidas, v. III, Charles Baudelaire, um lírico no auge do capitalismo, trad. de J.C.M. Barbosa e H.A. Baptista, São Paulo: Brasiliense, 1989.

Paulo: EditoraUFMG/Imesp, 2007[1935].

Paris, capital do século XIX. In: Passagens. Belo Horizonte/São 
. Walter Benjamin. Coleção Os Pensadores (Orgs. Flávio R. Kothe e Florestan Fernandes), São Paulo: Ática,1985.

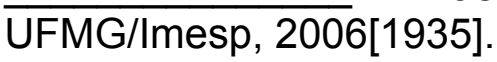

Passagens. Belo Horizonte/São Paulo: Editora

. Baudelaire e a modernidade. São Paulo: Autêntica, 2015.

BERARDI, Franco "Bifo". And phenomenology of the end. South Pasadena, Estados Unidos: Semiotext(e), 2013.

Pasadena, Estados Unidos: Semiotext(e), 2009.

. The Soul at work - From alienation to autonomy. South . The Uprising - On poetry and finance. South Pasadena, Estados Unidos: Semiotext(e), 2012.

BHABHA, Homi K. O local da cultura. Belo Horizonte: Ed. UFMG, 1998.

BOURDIEU, Pierre. Sobre a Televisão, a influência do jornalismo e os jogos olímpicos. Rio de Janeiro: Editora Zahar, 1997.

BRANDÃO, Carlos Rodrigues. O que é Eduçação? São Paulo: Editora Brasiliense, 1993.

BRENNAN, David. TV Conectada - como as qualidades analógicas da TV criaram uma supermídia digital. Rio de Janeiro: TV Globo, 2016.

BROOKER, Will et JEREMYN, Deborah (editores). The audience studies reader, Londres, Inglaterra: Routledge, 2008.

CALHOUN, 1994, Social theory and the politics of identity. Massacussets, Estados Unidos: Blackwell, 1994.

CASTELLS, Manuel. O poder da comunicação. Rio de Janeiro: Paz e Terra, 2015.

CASTELLS, Manuel. O Poder da Identidade - Vol. 2, Rio de Janeiro: Paz e Terra, 1999.

CANCLINI, Néstor Garcia. (1997). Cultura y comunicación: entre lo global y lo local. La Plata, Argentina: Universidad Nacional de La Plata.

CANGUILHEM, Georges. O Normal e o patológico. Rio de Janeiro, Forense Universitária, 2009.

CARPENTER, Edmund at McLuhan, Marshall. Revolução na comunicação. Rio de Janeiro: Jorge Zahar Editores, 1980. 
CHARNEY, Leo et Schwarz, Vanessa R. O Cinema e a invenção da vidamoderna. São Paulo: Cosac Naify, 2010.

CLARK, Walter et PRIOLLI, Gabriel. Campeão de audiência. São Paulo: Editora Best Seller, Brasil, 1991.

CRARY, Jonathan. Técnicas do observador: visão e modernidade no século XIX. Rio de Janeiro: Contraponto, 2012.

Moderna. São Paulo: Cosac Naify, 2014.

Suspensões da percepção: atenção, espetáculo e cultura . 24/7: Capitalismo tardio e os fins do sono. São Paulo: Cosac

Naify, 2015.

CRISELL, Andrew. A Study of modern television: thinking inside the box. Nova York, Estados Unidos: Palgrave MacMillan, 2006.

DEBRAY, R. Vida e morte da imagem. Petrópolis: Vozes, 1994.

DELEUZE, Gilles. Conversações. São Paulo: Ed. 34, 2008.

DELEUZE, Gilles. Francis Bacon. The Logic of sensation. Londres, Inglaterra: Continuum, 2003.

DELEUZE, Gilles. A Dobra - Leibniz e o barroco. São Paulo: Editora Papirus, 2007.

DIJK. Teun Adrianus van. Cognição, discurso e interação. 4ª ${ }^{a}$ ed. São Paulo: Contexto, 2002.

DUPOND, Pascal. Vocabulário de MerleauPonty. WMF Martins Fontes, São Paulo, 2010.

FLUSSER, Vilém. O mundo codificado: por uma filosofia do design e da comunicação. São Paulo: Cosac Naify, 2007.

FOUCAULT, Michel. A Ordem do discurso. São Paulo: Edições Loyola, 1996.

O sujeito e o poder. In: DREYFUS, H.; RABINOW, P. Michel Foucault, uma trajetória filosófica. Rio de Janeiro: Forense Universitária, 1995.

. Vigiar e Punir. Rio de Janeiro, Editora Vozes, 1975.

GALLOWAY, Alexander R. The interface effect. Malden, Estados Unidos: Polity Press, 2012.

et THACKER, Eugene. The Exploit - a theory of networks. Minneapolis, Estados Unidos: University of Minesota Press, 2007. 
GORTON, Kristyn. Media Audiences - television, meaning and emotion. Edimburgo, Escócia: Edinburgh University Press, 2009.

HALL, Stuart. Da Diáspora: identidades e mediações culturais. Belo Horizonte: UFMG/Unesco, 2003.

HALL, Stuart. A identidade cultural na pós-modernidade. Rio de Janeiro: DP\&A, 2005.

HAN, Byung-Chul, A Sociedade do cansaço. Petrópolis: Editora Vozes, 2015.

HEIDEGGER, Martin. A questão da técnica. In: Scientiæ Studia, v. 5, n. 3, p. 375-98, São Paulo: Departamento de Filosofia - FFLCH - USP, 2007.

HEROLD JUNIOR, Carlos. Do corpo-motor ao corpo-informação: corporeidade e trabalho no capitalismo. Revista Brasileira de Ciências do Esporte, vol. 30, n.2, pp. 107-122. Curitiba, 2009.

HERREROS, Mariano Cebrián. Información televisiva: mediaciones, contenidos, expresión y programación. Madri, Espanha: Síntesis, 2003.

INNIS, Harold A. O Viés da comunicação. Petrópolis: Editora Vozes, 2008 [1951].

JAMESON, F. Postmodernism or, the cultural logic of late Capitalism. Durham: Duke University Press, 1991.

JOST, François. Comprendre la télévision. Paris: Armand Colin, 2005.

JOST, François. Seis lições sobre televisão. Porto Alegre: Sulina, 2009.

LEMBO, Ron. Thinking through television. Cambridge, Inglaterra: Cambridge University Press, 2000.

LEMOS, André. A comunicação das coisas - teoria do ator-rede e cibercultura. São Paulo: Annablume, 2013.

LIVINGSTONE, Sonia. The changing nature of audiences: from the mass audience to the interactive media user. In: Valdivia, A., (ed.) Companion to Media Studies. Blackwell companions in cultural studies. Oxford, Inglaterra: Blackwell Publishing, 2003.

LUVIZOTTO, Caroline. A Racionalização das tradições na modernidade: Trans/Form/Ação, Edição Especial, v. 36, p. 245-258, Marília, SP: Universidade Federal Paulista, 2013.

MACHADO, Arlindo. A Televisão Levada à Sério. São Paulo: Editora SENAC São Paulo, 2005. 
ciberespaço. São Paulo: Paulus, 2007.

MARCONDES FILHO, Ciro. O Escavador de silêncios: formas de construir e de desconstruir sentidos na comunicação - Nova Teoria da Comunicação II. São Paulo: Paulus, 2004.

O Princípio da Razão Durante: comunicação para os antigos e o bergonismo. Nova Teoria da Comunicação III - Tomo I. São Paulo: Editora Paulus, 2010.

O Rosto e a Máscara: o fenômeno da comunicação visto pelos ângulos humano, medial e tecnológico. São Paulo: Editora Paulus, 2013.

. Por que a Nova Teoria é uma forma diferente de se pesquisa o jornalismo. Revista FAMECOS - mídia, cultura e tecnologia. V.19, n. 3, pp. 759-774, setembro/dezembro 2012. Porto Alegre, 2012.

. Haverá vida após a internet? In Revista FAMECOS, n 16, pp3545. Porto Alegre, dezembro 2001.

. Comunicação e revelação. In: Revista Paulus. Vol.1, № 1, pp. 17-28, São Paulo: Editora Paulus, 2017.

MERCER, Kobena. Welcome to the jungle: identity and diversity, in: Rutherford, Jonathan, Identity: community, culture, difference. Londres, Inglaterra: Lawrence \& Wishart, 1990.

MERLEAU PONTY, Maurice. O entrelaçamento - o quiasma. In: MERLEAU-PONTY, Maurice. O visível e o invisível. São Paulo: Perspectiva, 2007.

. O Olho e o espírito. São Paulo: Cosac \& Naify, 2007.

. Fenomenologia da Percepção. São Paulo: Martins Fontes,1999.

MIĖGE, Bernard. A Sociedade tecida pela comunicação: técnicas de informação e da comunicação entre inovação e enraizamento social. São Paulo: Paulus, 2009.

MIĖGE, B. O pensamento comunicacional. Petrópolis: Vozes, 2000.

MEYROWITZ, J. The rise of glocality: New senses of place and identity in the global village. In A Sense of Place: The Global and the Local in Mobile Communication; Nyíri, J.K., Viena, Áustria: Editora Passagen Verlag, 2005; pp. 21-30.

MORIN, Edgar. A Alma do Cinema. In XAVIER, Ismail (org.) A Experiência do Cinema. Rio de Janeiro: Global, 2003. 
MORLEY, David et SILVERSTONE, Roger. Domestic Communication Technologies and Meanings. In: Media, Culture and Societey. Volume 12, pp. 31-55. Londres, Inglaterra: Sage, 1990.

PARENTE, André (org.). Imagem Máquina. São Paulo: Editora 34, 1993.

PEREIRA JÚNIOR, Luiz Costa. (org.) A Vida com a TV: o poder da televisão no cotidiano. São Paulo: SENAC São Paulo, 2002.

PEREBINOSSOFF, Phillippe, GROSS, Brian et GROSS, Lynne S. Programming for TV, Radio and the Internet. Burlington, Massachussets, Estados Unidos: Focal Press/Elsevier, 2005.

PISCITELLI, Alejandro. Post-televisión - ecologia de los médios en la era de internet. Barcelona, Espanha: Paidós, 1998.

POSTMAN, Neil. Technopoly - The Surrender of Culture to Technology. Nova York, Estados Unidos: Vintage Books, 1993.

Amusing ourselves to death - public discourse in the age os show business. Nova York, Estados Unidos: Penguim, 2005.

PRIOLLI, Gabriel. A Deusa ferida. São Paulo, Summus Editorial, 2000.

RABBOY, Marc, PROULX, Serge et WELTERS, Roxanne. Media policy, audiences and social demand. In: Television \& New Media, v. 2, n. 2, maio 2001, p. 95-115. Londres, Inglaterra: Sage, 2001.

RABINBACH, Anson. The human motor: energy, fatigue and the origins of modernity. Los Angeles, Estados Unidos: University of California Press, 1992.

RANCIĖRE, Jacques. A partilha do sensível - estética e política. São Paulo: Editora 34, 2005.

. O destino das imagens. Rio de Janeiro: Contraponto 2012.

Fontes, 2012.

O Espectador Emancipado. São Paulo: Editora WMF Martins

RHEINGOLD, Howard. Smart mobs: The next social revolution. Cambridge, Estados Unidos: Basic Books, 2003.

RICOEUR, Paul. Tempo e Narrativa (tomos I e II). Campinas, São Paulo, Editora WMF, 2016.

RUSHDIE, Salman. Oriente, ocidente. São Paulo: Companhia das Letras, 1995.

SHAVIRO, Steven. Without Criteria: Kant, Whitehead, Deleuze and Aesthetics. Massachusetts Institute of Technology, 2009. 
SHIRKY, Clay. Lá vem todo mundo: O Poder de Organizar sem Organizações, Rio de Janeiro: Zahar, 2012.

. A cultura da participação. Criatividade e generosidade no mundo conectado. Rio de Janeiro: Zahar, 2011.

SONTAG, Susan, On Photography. Nova York, Estados Unidos: Farrar, Straus and Giroux, 1977.

SOUSA, Mauro Wilton de, Comunicação e cultura: práticas sociais em debate. In: Revista Paulus. Vol.2, № 3, pp. 17-28, São Paulo: Editora Paulus, 2018.

SOUSA, Mauro Wilton de et SAAD, Elizabeth (orgs.) Mutações do espaço público contemporâneo. São Paulo: Editora Paulus, 2014.

SOUSA, Mauro Wilton de (org.). Sujeito, o lado oculto do receptor. São Paulo: Brasiliense, 1995.

SOUZA, José Carlos Aronchi de. Gêneros e formatos na televisão brasileira. São Paulo: Summus Editorial, 2004.

SPYER, Juliano. Conectado: o que a internet fez com você e o que você pode fazer com ela. Rio de Janeiro: Zahar, 2011.

STAM, Robert e SHOHAT. Ella. Crítica da imagem eurocêntrica. São Paulo: Cosac e Naify, 2006.

STENGERS, Isabelle. Thinking with whitehead. Cambridge, Massachusetts, Estados Unidos, Harvard University Press, 2011.

STIEGLER, Bernard. Automatic society: the future of work, Vol.1. Cambridge, Reino Unido: Polity Press, 2016.

WILLIAMS, Raymond. Television: technology and cultural form. Londres, Inglaterra: Routledge, 2003.

Keywords - a vocabulary of culture and society. Oxford,

Inglaterra, Oxford University Press, 1976.

WOLFF, Michael. Television is the new television: the unexpected triumph of old media in the digital age. Nova York, Estados Unidos, Penguim, 2015.

WU, Tim. The master switch: the rise and fall of information empires. Nova York, Estados Unidos: Vintage Books, 2010.

. The attention merchats. The epic scramble inside our heads.

Nova York, Estados Unidos: Vintage Books, 2016. 


\subsection{Bibliografia eletrônica}

A TV Nos Liga

Disponível em:

http://redeglobo.globo.com/rs/rbstvrs/noticia/2014/08/tv-nos-liga-rbs-tv-lanca-novacampanha-institucional.html

Último acesso em 23 de março de 2018.

BALTAR, Mariana. Engajamento afetivo e as performances da memória. In Revista ECOPÓS - v.10, n.2, p. 96112, julho./dez. 2007. Rio de Janeiro: Universidade Federal do Rio de Janeiro.

Disponível em:

http://www.pos.eco.ufrj.br/ojs2.2.2/index.php/revista/issue/view/2/showToc

Último acesso em 23 de março de 2018.

BENTES, Ivana, Guerrilha de sofá.

Disponível em: http://www1.folha.uol.com.br/fsp/mais/fs3103200205.htm

Último acesso em 23 de março de 2018.

BERARDI, Franco 'Bifo'.

Palestra Futurability - The age of impotence and the horizon and possibility. Proferida em 25 de maio de 2017 e publicada em 31 de maio de 2017 no Institute of Contemporary Arts (ICA), de Londres, Inglaterra.

Disponível em:

https://www.youtube.com/watch?v=licAVwkw2zM

Último acesso em 23 de março de 2018.

BILTON, Nick. Reclaiming our (real) lives from social media.

Disponível em:

https://www.nytimes.com/2014/07/17/fashion/reclaiming-our-real-lives-from-socialmedia.html

Último acesso em 22 de março de 2018.

BURGESS, Matt. What is the Internet of things? Wired explains.

Disponível em:

http://www.wired.co.uk/article/internet-of-things-what-is-explained-iot

Último acesso em 23 de março de 2018.

BRUNA, Maria Helena Varella. Síndrome de burnout.

Disponível em:

https://drauziovarella.com.br/doencas-e-sintomas/sindrome-de-burnout/

Último acesso em 23 de março de 2018.

FECHINE, Yvana. Programação direta da TV: sentido e hábito. In: Significação Revista Brasileira de Semiótica, N. 22, pp. 41-57, São Paulo: Annablume, 2004. Disponível em:

http://www4.pucsp.br/cos/cps/pt-br/arquivo/Biblio-Yvana4.pdf

Último acesso em 23 de março de 2018. 
FORSTER, Ricardo. O semiocapitalismo.

Disponível em:

http://www.ihu.unisinos.br/78-noticias/570100-o-semiocapitalismo

Último acesso em 22 de março de 2018.

FUENTES, André. Brasil é o $9^{\circ}$ país com a pior velocidade de internet banda larga.

Disponível em:

http://veja.abril.com.br/blog/impavido-colosso/brasil-e-o-9-pais-com-a-pior-

velocidade-de-internet-banda-larga/

Último acesso em 23 de março de 2018.

IBÁÑEZ, Juan Înigo. Uma entrevista com Franco Berardi.

Disponível em:

https://arlindenor.com/2017/03/03/9963/

Último acesso em 23 de março de 2018.

KUBEY, Robert Kubey, CSIKSZENTMIHALYI, Mihaly. Television addiction Is no mere metaphor.

Disponível em:

http://www.scientificamerican.com/article.cfm?id=television-addiction-is-n-2002-02

Último acesso em 23 de março de 2018.

LANCHESTER, John. Você é o produto: Mark Zuckerberg e a colonização das redes pelo Facebook.

Disponível em:

http://piaui.folha.uol.com.br/materia/voce-e-o-produto/

Último acesso em 23 de março de 2018.

LEKAKOS, George, CHORIANOPOULOS, Kostas et SPINELIS, Diomidis. Information Systems in the living room: a case study of personalized interactive TV design. Global Co-Operation in the New Millennium. The 9th European Conference on Information Systems. Bled, Slovenia, June 27-29, 2001.

Disponível em:

http://www.csrc.Ise.ac.uk/Support/ECIS2001/pdf/032_Lekakos.pdf

Último acesso em 23 de março de 2018.

. The Challenge of Cchanging audiences: or, What is the audience

researcher to do in the age of the internet? In: European Journal of Communication.

Disponível em:

http://ejc.sagepub.com/content/19/1/75.abstract

Último acesso em 23 de março de 2018.

LOPES, Luis Carlos. A Centralidade da TV nas Redes Intersubjetivas Brasileiras.

Disponível em:

http://www.gmjei.com/journal/index.php/hip-text/article/view/192/176

Último acesso em 23 de março de 2018.

comunicação.

A TV aberta brasileira: economia, política, cultura e 
Disponível em: http://www.ucm.es/info/especulo/numero33/tvaberta.html Último acesso em 23 de março de 2018.

LOPEZ, José Àngel Plaza. ¿Qué sabe tu móvil de tu tristeza?

Disponível em:

https://retina.elpais.com/retina/2017/11/27/innovacion/1511787603 364241.html

Último acesso em 23 de março de 2018.

NATÁRIO, Eduardo et WAJNMAN, Solange. O controle remoto e a interatividade na televisão.

Disponível em:

http://www.e-compos.org.br/e-compos/article/view/60/60

Último acesso em 23 de março de 2018.

ROCHA, Simone Maria. Os visual studies e uma proposta de análise para as (tele)visualidades.

Disponível em:

http://www.revistas.usp.br/significacao/article/view/99767/121185

Último acesso em 23 de março de 2018.

SORGINE, Cecília. Brazil's tech junkies seek healing at digital detox clinic.

Disponível em:

http://www.spacedaily.com/reports/Brazils_tech_junkies_seek_healing_at_digital_det ox_clinic 999.html

Último acesso em 23 de março de 2018.

STRAUDBHARR, Joseph, D. et al. Changing class formations and changing television viewing: the new middle class, television and pay television in Brazil and Mexico, 2003-2013.

Disponível em:

https://www.cairn.info/revue-les-enjeux-de-l-information-et-de-la-communication-

2016-2-page-207.htm

Último acesso em 23 de março de 2018.

STEWART, James B. Facebook has 50 minutes of your time each day. it wants more.

Disponível em:

https://www.nytimes.com/2016/05/06/business/facebook-bends-the-rules-of-

audience-engagement-to-its-advantage.html

Último acesso em 22 de março de 2018.

WHITE, Robert A. (ed.). Televisão como mito e ritual. (Parte I). São Paulo, set/dez de 1994. (Seção Artigos Internacionais). (temas relacionados: televisão)

Disponível em:

http://www.revistas.univerciencia.org/index.php/comeduc/article/view/4243/3974

Último acesso em 23 de março de 2018.

\section{Textos sem autor}

Disponível em: 
Brasil é um dos países mais desconectados do mundo.

https://tecnologia.uol.com.br/noticias/redacao/2017/03/01/brasil-e-um-dos-paises-

mais-desconectados-do-mundo-sao-70-milhoes-offline.htm

Último acesso em 23 de março de 2018.

Brasil está em $90^{\circ}$ ranking mundial de velocidade da internet

http://www.correiobraziliense.com.br/app/noticia/tecnologia/2015/01/16/interna_tecno logia,466727/brasil-esta-em-90-no-ranking-mundial-de-velocidade-da-internet.shtml Último acesso em 23 de março de 2018.

Facebook atinge a marca de 2 bilhões de usuários no mundo.

Disponível em:

http://idgnow.com.br/internet/2017/06/27/facebook-atinge-a-marca-de-2-bilhoes-deusuarios-no-mundo/

Último acesso em 23 de março de 2018.

Twitter ganha apenas 9 milhões de usuários no $1^{\circ}$ trimestre

Disponível em:

http://idgnow.com.br/internet/2017/05/03/twitter-ganha-apenas-9-milhoes-de-

usuarios-no-10-trimestre/

Último acesso em 23 de março de 2018.

Dona do Snapchat registra número de usuários abaixo do esperado e ações caem

Disponível em:

http://www.scribblelive.com/blog/2015/06/10/new-content-marketing-strategy-utilize-

snapchat-meerkat-twitter-periscope/

Instagram tem 800 milhões de usuários ativos por mês e 500 milhões por dia

Disponível em:

https://g1.globo.com/tecnologia/noticia/instagram-tem-800-milhoes-de-usuarios-

ativos-por-mes-e-500-milhoes-por-dia.ghtml

Último acesso em 23 de março de 2018.

Conceito de Cibernética.

Disponível em:

https://www.merriam-webster.com/dictionary/cybernetics

Último acesso em 19 de fevereiro de 2018.

Most famous social network sites worldwide as of January 2018, ranked by number of active users (in millions).

Disponível em:

https://www.statista.com/statistics/272014/global-social-networks-ranked-by-numberof-users/

Último acesso em 23 de março de 2018. 


\section{Redes sociais}

www.facebook.com

www.instagram.com

https://live.fb.com/

www.periscope.com

www.snapchat.com

www.youtube.com

www.whatsapp.com 